\title{
THE LATE BRONZE AGE POTTERY IN THE SOUTH-EASTERN CARPATHIAN BASIN
}

\author{
V I C T O R S A V A
}

\begin{abstract}
After the abandonment of some of the Middle Bronze Age tell settlements, a series of developments and transformations lead to the construction of mega-forts in the Lower Mures Region during the $15^{\text {th }} \mathrm{c}$. BC, followed by their subsequent destruction/demise during the $13^{\text {th }} \mathrm{c}$. BC. While most investigations in the aforementioned region have focused on the evolution of the most representative sites, a large number of artefacts, especially the pottery assemblage, have not yet been analysed in detail. The current paper aims to fill this gap by presenting a detailed analysis combining the available radiocarbon dates, the contexts from where these samples were taken, and the associated pottery finds. In this way we could establish time intervals expressed in absolute dates that frame the evolution of certain pottery shapes, decoration techniques and ornamental motifs. As a result of this analysis, it became clear that certain characteristics of the Middle Bronze Age pottery have been perpetuated during the Late Bronze Age. Another important observation was the widespread use of channelled pottery as early as the $16^{\text {th }} \mathrm{c}$. BC within some communities from this region. On the other hand, other communities in the area make extensive use of incised decoration until the $14^{\text {th }} \mathrm{c}$. BC. As a result, two different stylistic areas could be observed in the Lower Mureș Region. The results obtained in this paper underline the drawbacks of traditional relative chronologies based on the evolution of certain artefact types. Therefore, a chronological scheme based on major events taking place in the Lower Mureș Region, established following the analysis of a series of radiocarbon dates, is put forward in this paper.
\end{abstract}

Keywords: Late Bronze Age, Romania, Hungary, Lower Mureș, pottery, style, absolute chronology.

\section{INTRODUCTION}

Various chronological systems have been developed throughout time, systems that had to be subsequently refined as more absolute dates became available. Nowadays, our capacity to make chronological associations between artefacts, contexts, sites and events is strongly influenced by the number of existent radiocarbon dates. The aim of this paper is to establish absolute ranges for the Late Bronze Age pottery in a micro-region belonging to the broader inner Carpathian area: the Lower Mureș. This region lies in a contact area between the Romanian Western Carpathians and the Tisza floodplain, on the lower course of the Mureș River (Fig. 1). Major chronological markers in the region are the development of tell settlements throughout the Middle Bronze Age (MBA; ca. 2000-1600/1500 BC), sites that due to reasons still under debate were abandoned throughout the $16^{\text {th }} \mathrm{c}$. BC, followed by the establishment, at the beginning of the Late Bronze Age (LBA; during the $15^{\text {th }}$ c.), of mega-forts that extend over areas ranging from tens to hundreds and thousands of hectares. ${ }^{1}$ Throughout the $13^{\text {th }} \mathrm{c}$., the most representative megaforts reached the end of their existence (Gogâltan 2017; Gogâltan/Sava 2019; Krause et al. 2019; Molloy et al. 2020; Sava/Gogâltan/Krause 2019; Szeverényi et al. 2017).
The importance of this micro-region is highlighted by the development during the last two decades of several research projects targeted at the investigation of MBA tells (such as Pecica-Șanțul Mare) and LBA mega-forts (Sântana-Cetatea Veche, Cornești-Iarcuri, Gradište Iđoš and CsánadpalotaFöldvár). Although certain aspects of the MBA and LBA, such as the internal trajectory of sites, their character and function, have been studied, there are few studies dealing with one of the most essential aspects of this period, namely the absolute dating of the pottery. The lack of a reliable chronology, especially for the LBA, has led to numerous confusions among specialists, while correlating the traditional relative chronologies to the newly available dates is becoming an increasingly difficult, if not impossible, task.

In order to overcome these shortcomings and provide explanations for the profound transformations taking place within Bronze Age society, a new model based on the correlation of absolute dates, the contexts from which they were taken, associated pottery and major events that can be identified in the archaeological record was developed. For the Lower Mureș Basin a database has been compiled that up to the present moment contains over 150 radiocarbon dates, most of them coming from newly

\footnotetext{
1 For MBA and LBA, I have used Florin Gogâltan's relative chronological system summarized in Gogâltan 1999, 71-78; 2001; 2015; 2019
} 


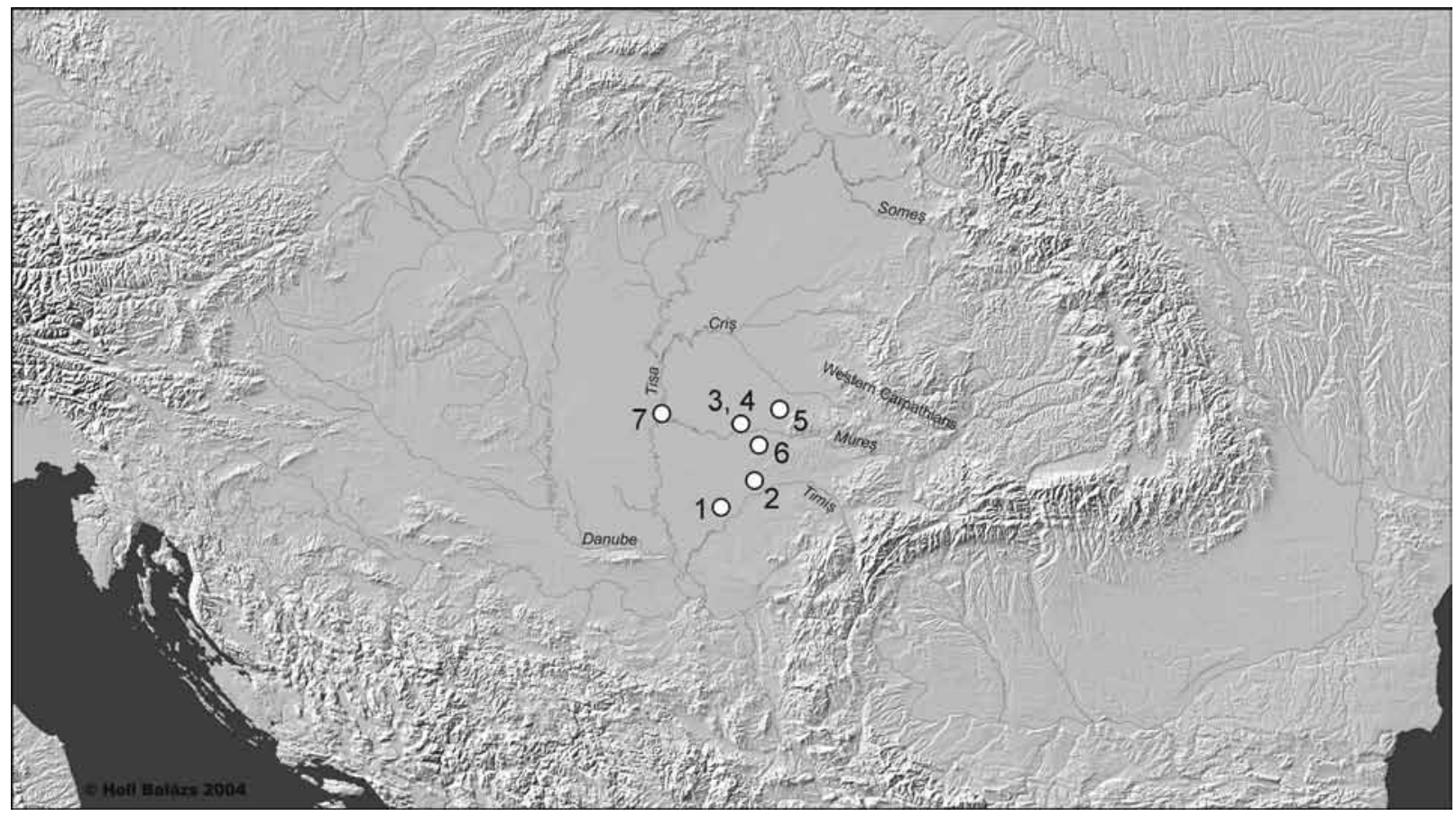

Fig. 1. Map of the Intra-Carpathian region with the sites where the analysed contexts were found. 1 - Foeni-Gomila Lupului; 2 - Giroc-Mescal; 3 - Pecica-Est; 4 - Pecica-Site 14; 5 - Sântana-Cetatea Veche; 6 - Șagu-Site A1_1; 7 - Tápé. The map of the Intra-Carpathian region was realised by H. Balász (http://www.ace.hu/igcp442/maps.html).

excavated LBA sites. However, as most of these sites are still under investigation, or the publication of the results is still in progress, only 39 dates come from published or known contexts with associated artefacts. Only 33 of these 39 contexts (coming from seven sites) have clear correlations between the radiocarbon dates, their contexts and the associated pottery. Most of these dates fall within an interval ranging from the $16^{\text {th }} \mathrm{c}$. to the first half of $13^{\text {th }} \mathrm{c}$. BC, which corresponds with the abandonment of the tell sites, the construction of mega-forts and the end of some of these latter sites.

As is the case with every archaeological phenomenon, the events that took place during the LBA in the Lower Mureș and their material expressions cannot be studied in a coherent manner in the absence of an overview of the main pottery styles distributed in the inner Carpathian region and surrounding areas. The next step is a discussion of the sites and contexts from which the AMS radiocarbon dates have been taken. The results obtained from the association of contexts, pottery and their respective dates will be individually discussed and illustrated. For the first time in the region under study, the typo-chronological analysis of the pottery will be combined with the study of the features where the pottery was uncovered and the absolute dating of each feature. The approach and interpretation of the data suggested here diverge from previous views regarding LBA chronology, allowing at the same time for new answers to be given to a complex issue. The analysis also results in an unambiguous chronological scheme regarding the pottery evolution in this region, despite the considerable variety in pottery form and decoration between contemporary sites located in relative geographic proximity.

\section{SETTING AND BACKGROUND}

\section{Late Bronze Age in the Lower Mureș}

The gradual abandonment of tell settlements after ca. 1600 BC coincides with the appearance of new settlements and cemeteries that are assigned to the LBA (Gogâltan 2015, 72, 73; Sava/Gogâlttan 2019). As proven by recent radiocarbon dates collected from some tells located in the Lower Körös Basin (Duffy et al. 2019, tab. 3; fig. 4), as well as from MBA cemeteries in the Lower Mureș Basin such as Ostojićevo-Stari Vinogradi (O'Shea et al. 2019, fig. 3), the evolution of certain MBA sites continues long after the majority of tells have been abandoned. At the same time, there are proofs that during $1550-1450 \mathrm{BC}$ the European continent experienced a substantial population increase (Capuzzo et al. 2018) that most likely had a significant impact on the Lower Mureș. Based on the available evidence, it can be stated that the 
abandonment of tell settlements and the emergence of new settlements should be seen as a continuation of certain MBA traditions mixed with a series of Central-European influences on the material culture of the region, as well as on the local burial customs (Sava/Gogâltan 2019; Sava/Ignat 2016, 195, 196). This evidence also points towards an internal evolution of local communities that integrate and internalize a series of transformations occurring at a macro-regional level. A similar phenomenon, internal evolution towards a higher socio-political complexity, has also been recently demonstrated to have taken place in other European regions (Cavazzuti et al. 2019). During this chronological phase LBA I (ca. 1600/1550-1450 BC) we are witnessing a reorientation of the settlement network towards the foothills of the Apuseni Mountains, possibly due to the flow of raw materials from the mountain region to the low flatlands. Even though some settlements from this phase are fairly large, reaching up to 40 ha in size (for example, Pâncota-Site 16), there are no fortified settlements at this stage. It seems that in some settlements, such as Șagu-Site A1_1, intense metallurgical and agricultural activities were being conducted (Sava/Hurezan/Mărginean 2011, 50-55, 74; 2012). Although during this period bronze artefacts are widespread, finds from the biritual cemetery in Pecica-Site 14 stand as proof that large numbers of bronze artefacts were being accumulated in only a few graves (Ignat/Sava 2019, 14, 15, fig. 11). Furthermore, the process of increasing social stratification that had its modest debut during the MBA becomes more salient during this period, as evidenced by marked differences in grave offerings, with hereditary social inequality being attested in the cemetery from Pecica-Site 14 (Sava/Andreica 2013, 65). It appears that in the region here under study there are two main types of cemeteries: on the one hand, in the lowlands of the Banat plain we have cremation cemeteries typical for the Cruceni-Belegiš area such as the ones at Livezile (Gogâltan 1998) and Cruceni (Radu 1971; 1973), on the other hand, in the Mureș Valley biritual cemeteries are the norm, such as the ones at Pecica-Site 14 (Ignat/Sava 2019) and Tápé-Széntéglaégető (Trogmayer 1975), where inhumation graves are predominant. Although the LBA I society continues certain MBA traditions, we can't help but notice that the new communities adapt to the new norms of the period. This entails the adoption of a new type of weapon, the sword, along with all the associated social connotations, such as the construction of a warrior identity (Sava/Ignat 2014, 18-29). The new social transformations taking place after the abandonment of the tell settlements, such as the widespread distribution of new occupations (warriors, metalworkers, etc.), heightened social stratification, population increase, greater uniformity in material culture over large areas and possibly an increase in long-distance trade and exchange with ever more distant regions gradually led to the emergence of one of the most impressive societies in the prehistory of the Carpathian Basin: that of the mega-forts.

In the Lower Mureș, after the abandonment of tell settlements, around $1450 \mathrm{BC}$, complex fortification systems that in some instances enclose areas of hundreds or thousands of hectares were being built. These fortifications span the entire LBA II (ca. 1450-1250 BC). Some of the most representative mega-forts are Cornești-Iarcuri (whose fortifications enclose an area of 1765 ha; Krause et al. 2019) and Sântana-Cetatea Veche, a site that stands out due to its rich assemblage, even if the fortified area covers only 130 ha (Gogâltan/Sava 2010; Gogâltan/Sava/Krause 2019). A main feature of these mega-forts is the presence of multiple defensive elements consisting of impressive earthen ramparts, palisades or even walls constructed on top of the earthen ramparts and one or two ditches up to $10 \mathrm{~m}$ wide and almost $3 \mathrm{~m}$ deep. Besides the two aforementioned mega-forts, the fortifications in Gradište Iđoš (Molloy et al. 2020) and Csánadpalota-Földvár (Szeverényi et al. 2017) should also be mentioned. The last two sites have a rather small central enclosure (up to $7 \mathrm{ha}$ ) surrounded by a network of ditches that enclose an area of up to 400 ha in size. Although less numerous than the MBA tells, mega-forts are also constructed in the floodplains, sometimes in the proximity of former tells (for example Sântana, Munar, Cornești). Even though archaeological excavations at these immense sites have mostly focused on their fortification systems, the application of non-invasive investigations such as geophysical surveys and LIDAR scanning coupled with test trenches have allowed for the reconstruction of the settlement structure and inner layout of these mega-forts. By far the most impressive results have been obtained at Sântana-Cetatea Veche, where 29 buildings ranging in size from 50 to $1700 \mathrm{~m}^{2}$ have been identified so far (Gogâltan/Sava/Krause 2019, 199, 200, fig. 7-10). Furthermore, gold, bronze, faience and glass artefacts uncovered at Sântana are indicative of intense craft activities being conducted at the site, doubled by the engagement of the megafort in long-distance trade and exchange networks. Dense networks of unfortified sites, some of them dating back to the LBA I, surround these mega-forts (Sava/Ignat 2016, fig. 16). While most settlements are scattered over areas ranging from $7 / 8$ to $25 \mathrm{ha}$, there are also much smaller settlements such as the one from Șagu-Site 2 that covers an area of only 2,1 ha. Archaeological excavations undertaken in the region have revealed that on some of these settlements, such 
as the one from Șagu-Site A1_1 intense craft activity (especially metalworking and pottery manufacture) were undertaken besides agriculture (Sava/Hurezan/ Mărginean 2011, 50-63). A further example is the Szöreg C settlement that has yielded clear evidence of intense metalworking (Fischl 2000, fig. 20; 21; Mozsolics 1985, 196, 197, tab. 273; 274). Long and mediumdistance trade and exchange coupled with a rich metallurgical and agricultural production have led to an unprecedented accumulation of wealth during the LBA II that finds its material expressions in the numerous gold and bronze hoards and single finds of the period (Boroffka/Luca 1995, 225, 226, fig. 1: 15; Dömötör 1897, 264; Dörner 1970, 460, fig. 14: 4; Gogâltan/ Sava 2014; Kacsó 1993; 2015, 30, 31, fig. 4: 6-9; Kemenczei 1991; Mureșan/Caba 2007; Petrescu-Dîmbovița 1977, 64, 102, 107, 119, 157, pl. 55: 1-11; 186: 17, 18; 187; 277: 14-16; 374: 8-10; Soroceanu 2012, 122, 123, note 46, taf. 45: $2 ; 46: 6,8 ; 47: 2,6)$. The funerary finds of this interval are represented by the second phase of the cemeteries from Pecica-Site 14 and Tápé (Trogmayer 1975), ${ }^{2}$ alongside some isolated finds and smaller burial grounds (Foltiny 1957; Ignat/Sava 2019, 8; Nagy 2005). The burial mounds from Susani were probably erected around 1400 BC (Diaconescu et al. 2018b, 27), while pottery depositions of the type encountered at the mound from Susani-Grămurada lui Ticu (Stratan/ Vulpe 1977, 46-53) are generally later than the actual period of use of these mounds as burial grounds.

The constant flow of copper and tin led to a widespread distribution and availability of bronze artefacts during LBA II. This is why the control of trade routes and the defence of redistribution centres were the main priorities of the period (Kristiansen/ Suchowska-Ducke 2015, 369-373). In the context of a growing need of defending these immense megaforts, protecting the trade routes or maintaining the status quo within society, the prestige and importance of professional warriors grew (Krause 2019a). This is expressed in the material record by a marked increase in the number of weapons (Gogâltan/Sava 2018; Sava/Ignat 2014). Archaeological investigations of the fortification system from Sântana have brought to light evidence suggesting the existence of multiple violent conflicts culminating in a final siege that ultimately led to the destruction of the fortifications towards the end of the $14^{\text {th }} \mathrm{c}$. or the beginning of the $13^{\text {th }}$ c. BC (Gogâltan/Sava/Krause 2019, 209, fig. 22-24; Sava/Gogâltan/Krause 2019, 170-174). A rather similar situation is encountered at Cornești, where a succession of violent events could be documented beginning with the $15^{\text {th }} \mathrm{c}$. BC that continue throughout the $14^{\text {th }} \mathrm{c}$. BC and ultimately lead to the abandonment of the first two fortification rings in the first half of the $13^{\text {th }}$ c. BC (Lehmphul et al. 2019, 273-275, tab. 8).

As a result of the destruction of the mega-forts from Sântana and Cornești and the abandonment of LBA I and II settlements, the Late Bronze Age society of the Lower Mureș underwent major transformations. So far, there are only isolated instances where continuity in settlement from the preceding phase could be documented. This is the case for example at Cornesti-Iarcuri, where there are some indications that the area of the fortification was used until the Early Iron Age (EIA); however, the intensity of use decreased dramatically compared to earlier periods, and there are breaks in the occupation of the site (Lehmphul et al. 2019, 275, 276, tab. 9); at Gradište Iđoš, following an intense useperiod of the site during the LBA, the settlement was re-settled during the EIA after a break of almost two centuries (Molloy et al. 2020, 15-17, tab. 3). At the same time, during LBA III there is a significant decrease in the number of settlements and bronze hoards. This phase is insufficiently documented in the Lower Mures especially due to the dearth of archaeological finds that could be assigned to this interval. However, beginning with the end of the $12^{\text {th }}$ c. BC, new power centres emerge in Transylvania (Bălan 2013; Hansen 2019a; Uhnér et al. 2019; Vasiliev/Aldea/Ciugudean 1991).

\section{Pottery styles of the Late Bronze Age}

The relative chronology of the LBA in the inner Carpathian area has been divided into three or four distinct phases, depending on the scholars who devised the respective schemes (Ciugudean 2010, fig. 4; Gogâltan 2001, 196-199; 2019, 49-57; Kacsó 1990; Kemenczei 1984, 87-96; Marta 2009, 104; Popal Totoianu 2010, 240-250, tab. 1; Przybyła 2009, 54-58; Sava/Gogâltan 2019; Sava/Ignat 2016, 192-196). Recent studies have tried to incorporate, more or less successfully, the new radiocarbon dates into the existing relative chronologies (Ciugudean/Quinn 2015; Ciugudean et al. 2019; Gogâltan 2019; Harding/Kavruk 2013). The newly available radiocarbon dates have also led to substantial revisions of the chronological framework of the LBA, resulting in some instances to the traditional chronology being pushed back up to 300 years (Fig. 2).

The gradual social and economic transformations that occurred after ca. $1600 \mathrm{BC}$, such as the end of tell settlements in western Romania (Gogâltan 2017, $36,37)$, the development of new settlements and cemeteries, the gradual change of burial customs

\footnotetext{
2 Another cemetery with a similar evolution to those from Tápé and Pecica-Site 14 is located in Velebit, in the immediate vicinity of our study region (Kapuran 2019).
} 

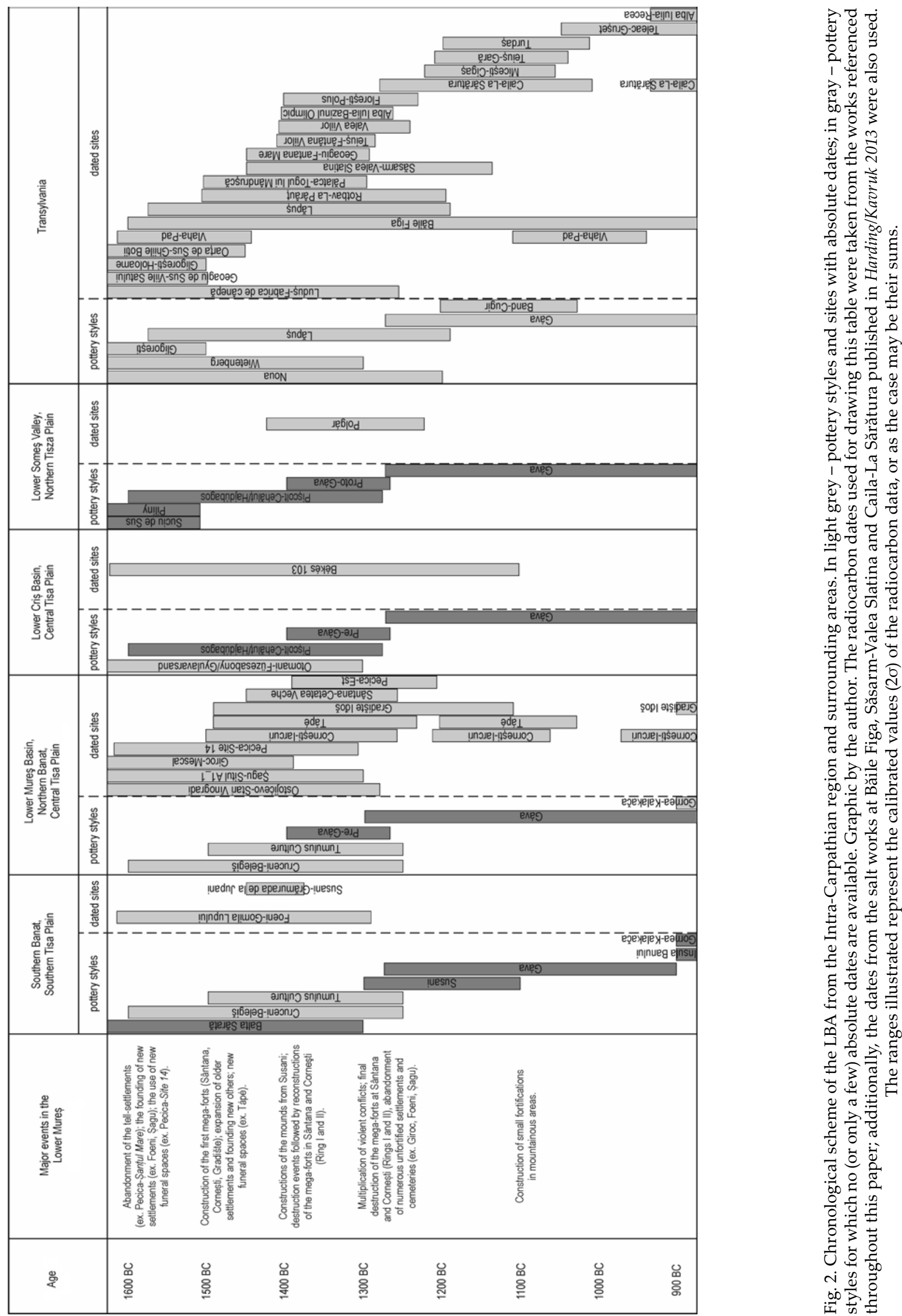
(Motzoi-Chicideanu 2011, 561-672), the unprecedented developments in metallurgy (Petrescu-Dîmbovița 1977), and considerable innovations in agriculture (Filipović et al. 2020; Stika/Heiss 2013), are also reflected in the appearance of new pottery styles. The Cruceni-Belegiš $\mathrm{I}^{3}$ pottery style, which in certain aspects represents a continuation of some MBA pottery traditions, develops in Banat between 1600 and 1400 BC. Characteristic shapes are biconical pots, dishes and cups with high handles rising above the rim. The typical ornamental motifs consist of incised arches and garlands, displayed horizontally or in zigzagged lines, as well as horizontal and vertical rows of pseudo-cord decoration (Gumă 1993, 150-153; 1997, 55-57). Parallel to the evolution of Cruceni-Belegiš (or possibly slightly earlier) is the development of the so-called Balta Sărată pottery style, spreading from the piedmont of Banat all the way to Transylvania. Despite the fact that the complete pottery assemblage characteristic for the first phases of this style is hard to define, it seems that pots and certain types of dishes were among the typical pottery shapes, while the diagnostic decoration is represented by successive stitches and triangular impressions, and, more seldom, channelling - a decoration technique that becomes more frequent during the later phases (Gumă 1997, 49, 50). In north-west Romania (Crișana, the Somes plain and Sătmar lowlands), Slovakia and north-east Hungary, the Suciu de Sus, Pișcolt-Cehăluț/Hajdúbagos and Piliny pottery styles that continue MBA ceramic traditions are encountered at this stage, with channelled decoration being frequently employed in all these groups (Furmánek 1977, 299-314; Furmánek/ Veliačik/Vladár 1991, 138-145; Kacsó 1990; Kemenczei 1984, 16-19; Marta 2009, 87-93; Marta et al. 2010, 65-69; Németi 2009, 212, 213; Pop 2009, 14-24). In the central and southern Tisza Plain there are western influences from the Tumulus Culture circle (Sánta 2011, 521-523; 2017, 102, 103; Trogmayer 1975). In Transylvania the MBA pottery of Wietenberg type continues to be in use until ca. $1300 \mathrm{BC}$, even if after 1600 BC the Noua pottery style spreads in eastern Transylvania, in the foothills of the south-eastern Carpathians, in central and northern Moldavia as well as in the northern Moldavian Republic (Bălan/ Quinn/Hodgins 2016, 86, 87; Boroffka 1994, 289, 290; Ciugudean/Quinn 2015; Quinn et al. 2020; Sava E. 2002,
216, 218-220). The cultural synthesis between late Wietenberg and Noua is known as "Gligorești" in the academic literature (Gogâltan/Popa 2016, 197, 198).

The rise of mega-forts in the Lower Mureș during the $15^{\text {th }}$ c. (Gogâltan/Sava 2010; Gogâltan/ Sava/Krause 2019; Krause et al. 2019; Lehmphul et al. 2019; Molloy et al. 2017; Sava/Gogâltan/Krause 2019; Szeverényi et al. 2017) is relatively parallel to the evolution of the Cruceni-Belegiš II phase. This pottery style is characterized by the continued use of the main pottery shapes of the previous phase, with a marked increase in the use of horizontal and vertical channellings or channellings displayed in a garland pattern. In Crișana and south-western Transylvania we encounter the Igrița pottery style (Andrițoiu 1992, 69-72; Chidioşan/Emődi 1982; 1983). In the foothills of the Banat region, the final phases of the Balta Sărată group are encountered at this time, characterized by the adoption of new shapes such as biconical vessels, biconical dishes, and cups with high arched handles; although incised and stitched ornaments are still encountered, channelled decoration becomes more widespread (Gumă 1993, 163-166; 1997, 64). In the Sătmar and Carei plains (north-western Romania), the Suciu de Sus and Pișcolt-Cehăluț/Hajdúbagos pottery styles continue their evolution, making extensive use of channelled decoration (Marta 2009, 38, 39; Németi 2009, pl. 1; 2). Parallel to the rise of megaforts on the Lower Mureș, the Lăpuș pottery style makes its appearance in the mountainous regions of north-western Romania (Kacsó 2001; 2011; Metzner-Nebelsick/Kacsó/Nebelsick 2010, 225). Where the Mures flows into the Tisza and in the southern Tisza Plain the influence of the Tumulus Culture continues until probably the end of the $14^{\text {th }} \mathrm{c}$. BC, or even the first part of the $13^{\text {th }} \mathrm{c}$. BC, through the Tápé cemetery. ${ }^{4}$ At the same time, the pottery known as Pre-Gáva starts to spread in the central Tisza Plain and the Lower Körös Basin, while in the north-eastern Tisza Plain the Proto-Gáva group is encountered (Szabó 2017). Between 1300-1200 BC the first elements of the Gáva or Gáva-Holihrady pottery style make their appearance in northern Romania, north-eastern Hungary, northern Moldavia and the Lower Mureș Basin (László 2019; Metzner-Nebelsick 2012, 67; Metzner-Nebelsick/Kacsól Nebelsick 2010, 223). The defining characteristics

\footnotetext{
3 For a short research history regarding the Cruceni-Belegiš style see Gumă 1993, 150-157 and Stavilă 2012, 32, 33. The pottery here defined as Cruceni-Belegiš is known in Serbia as Belegiš, while its later phase is termed Belegiš-Gáva (see Tasić 1984; 2001), or just Gáva (Bukvić 2000).

4 Among the AMS radiocarbon dates published in O'Shea et al. 2019 there is also the sample UGAMS-30830 taken from the cremation grave 188 that offers a very late date $1209-1038$ cal BC $(2 \sigma)$ - therefore the possibility that this cemetery was in use also during the $12^{\text {th }}-11^{\text {th }}$ centuries, even if most burials are dated to the $15^{\text {th }}-14^{\text {th }}$ centuries BC. A similar situation is encountered at Békés-Site 103 in the Lower Körös Basin, where the cemetery was in use for a long period of time, until the $11^{\text {th }}$ c. BC (Duffy et al. 2019, fig. 4).
} 


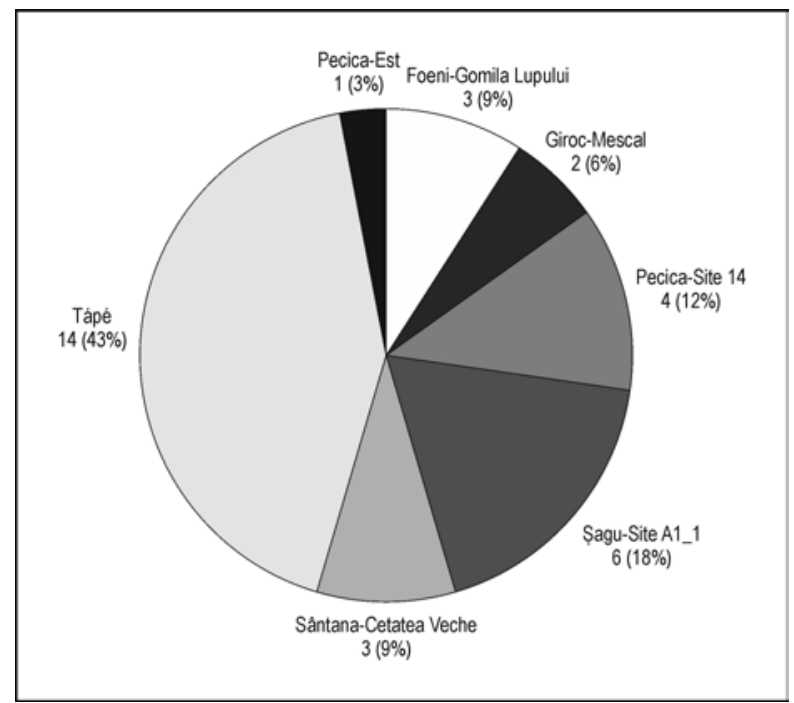

Fig. 3. Distribution of the number of contexts by site. Graphic by the author.

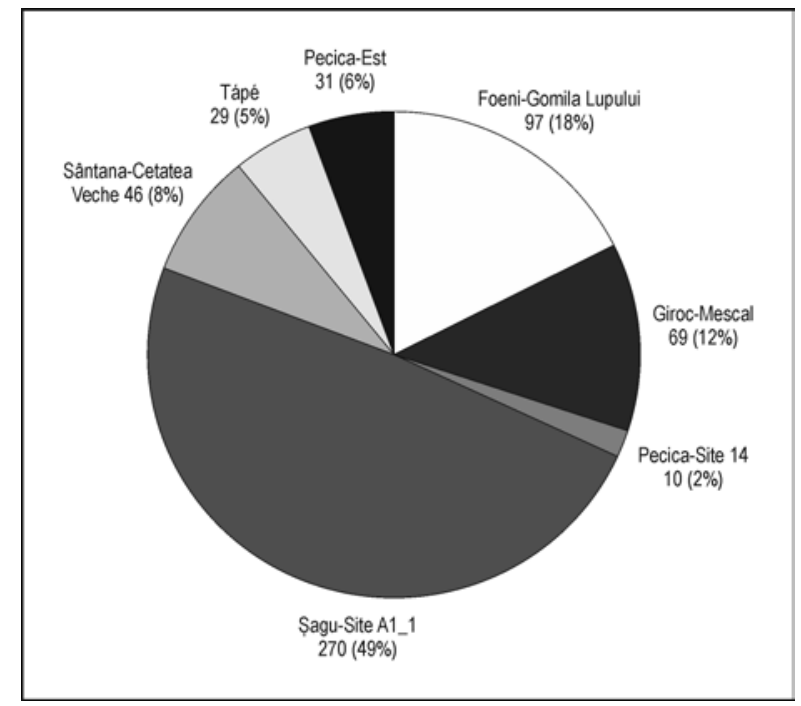

Fig. 4. Distribution of the number of pottery sherds by site. Graphic by the author.

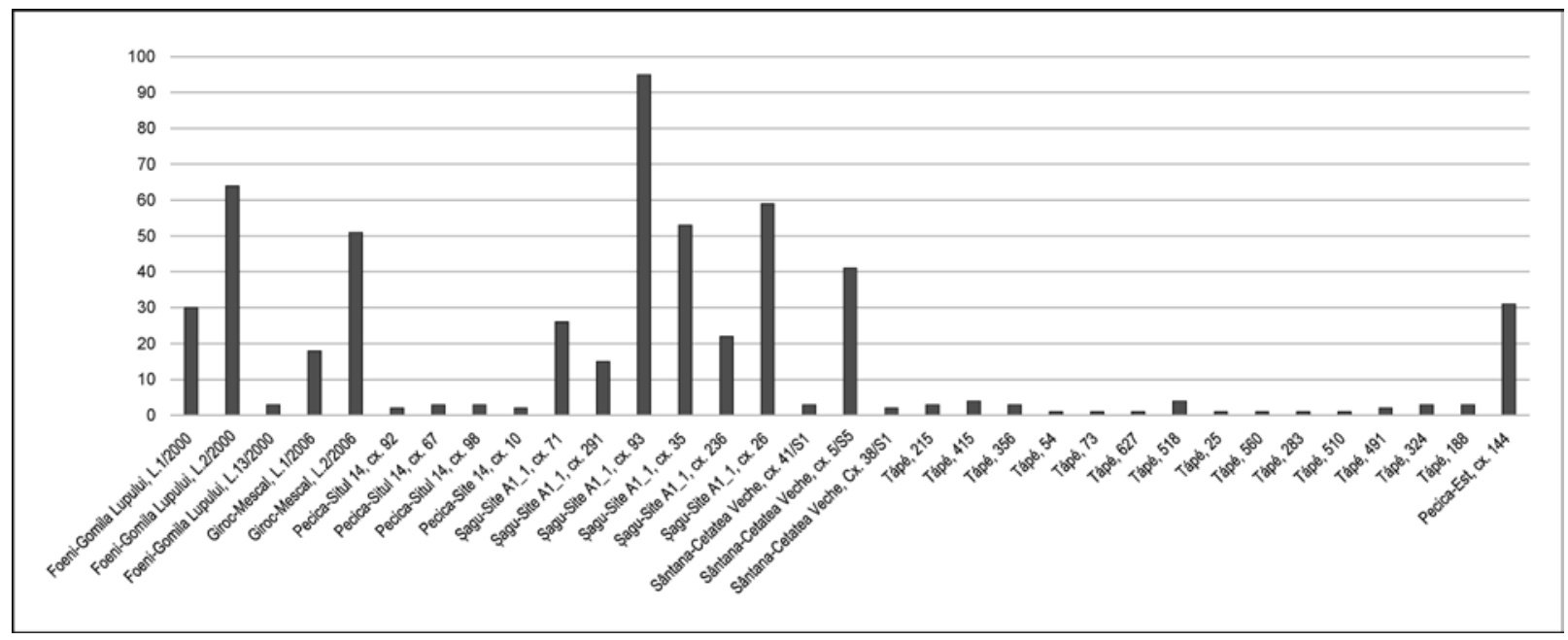

Fig. 5. Distribution of the number of pottery sherds by context and site. Graphic by the author.

of this style are an exponential increase in the use of channelled or fluted decoration and a new technique of firing pottery that leads to the vessels having shining black outer surfaces and red or brick-red inner surfaces. After $1100 \mathrm{BC}$ this pottery style also spreads to Transylvania. East of the Carpathians this group is sometimes being referred to as the Chișinău-Corlăteni pottery style (Bader 2012; Ciugudean 2012; Kósa 2018; László 1994; Levițki 1994; Metzner-Nebelsick 2012; Pankau 2004; Szabó 2017). These are the dominating pottery styles in the aforementioned regions until $900-800 \mathrm{BC}$. It should be mentioned that during the time period between 1300 and $1100 \mathrm{BC}$, the Bobda-Susani pottery style is encountered in Banat (Diaconescu et al. 2018a, 131, 132; 2018b, 29, 30; Gumă 1993, 168-180; Stratan/
Vulpe 1977, 46-53), which for a while has a parallel evolution to the early Gáva pottery in the Lower Mureș and northern Tisza Plain. In Transylvania, during 1200-1050 BC we encounter the Cugir-Band group characterized by an increased use of combed decoration, Kammstrich (Ciugudean et al. 2019).

\section{METHODS}

In establishing an absolute chronology of the Lower Mureș micro-region, data coming from the radiocarbon dating of 33 features originating from seven sites has been compiled; in total, these features entailed 552 complete vessels and pottery sherds (Fig. 3-5). These finds were then organized 


\begin{tabular}{|c|c|}
\hline 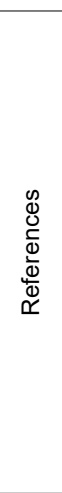 & 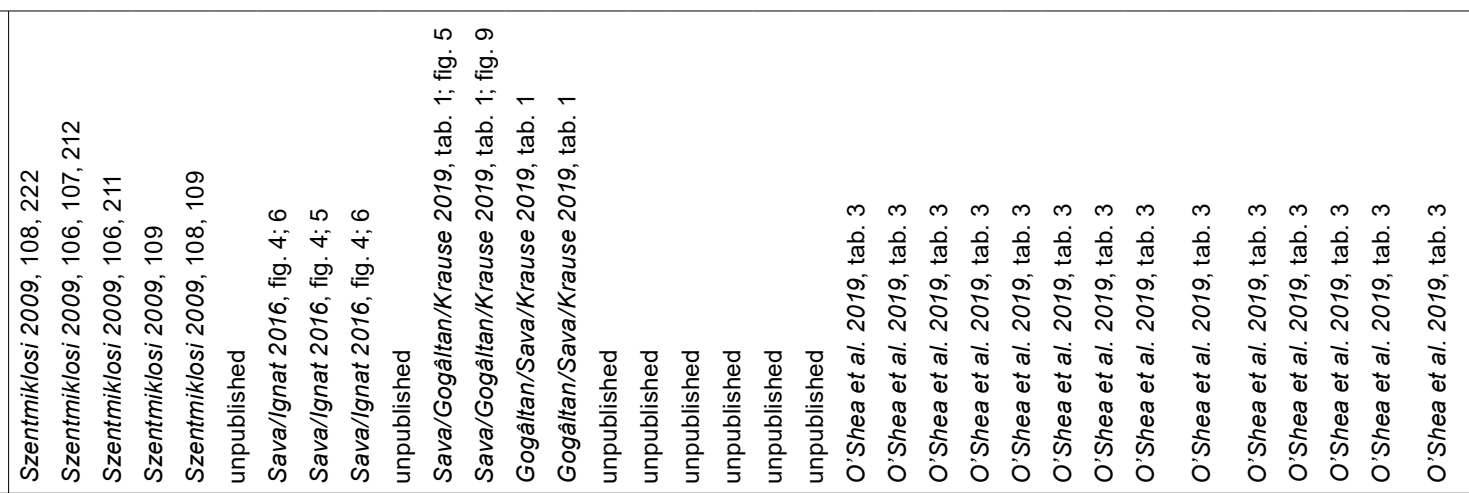 \\
\hline 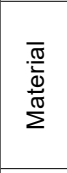 & 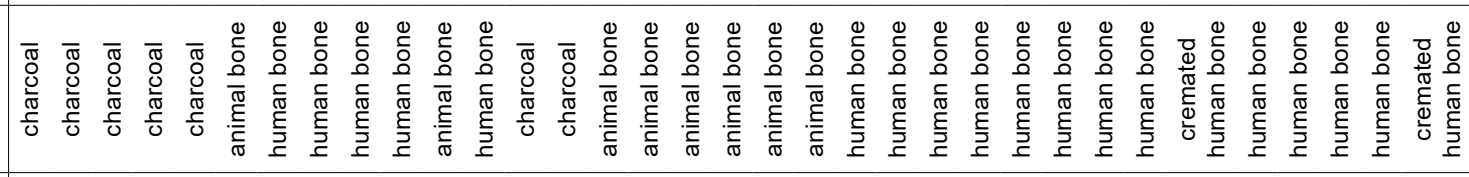 \\
\hline 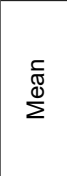 & 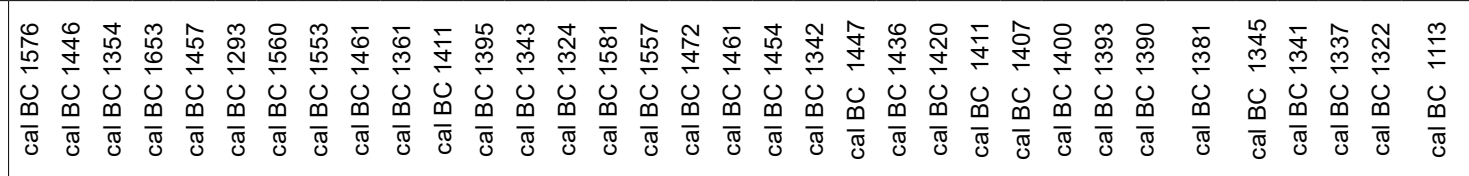 \\
\hline & 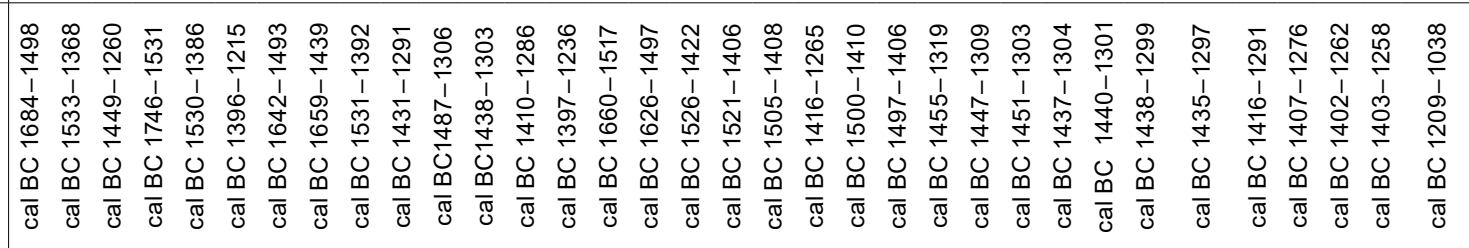 \\
\hline+1 & 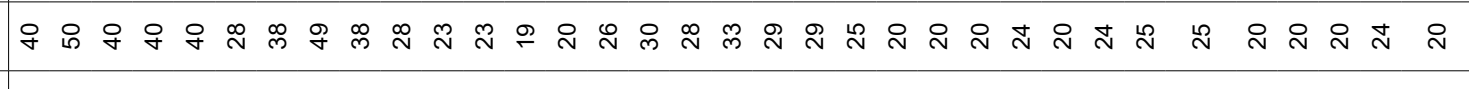 \\
\hline & 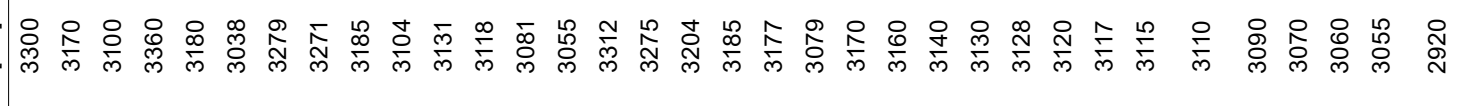 \\
\hline 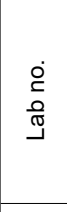 & 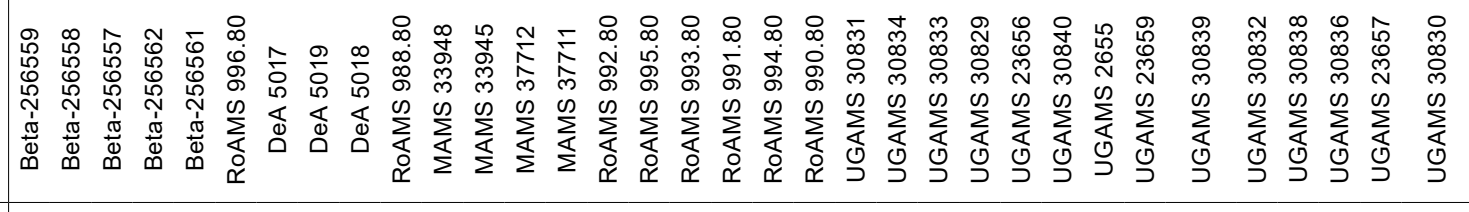 \\
\hline & 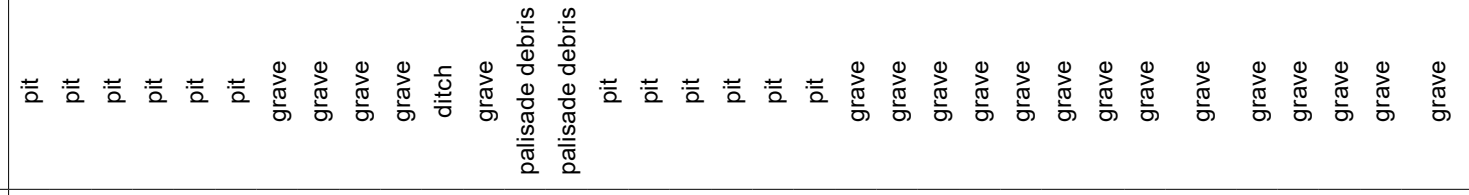 \\
\hline & 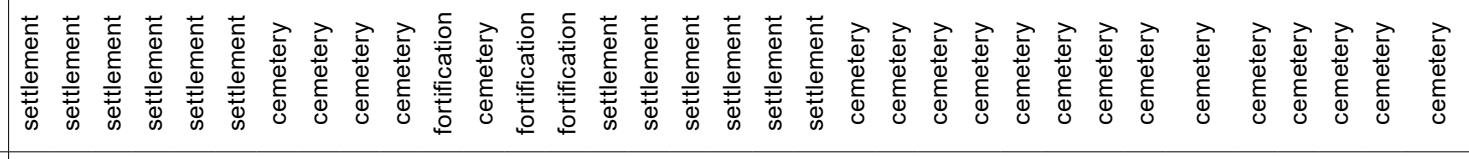 \\
\hline ' & 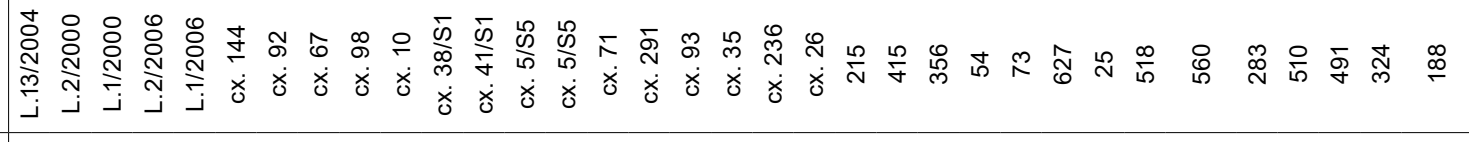 \\
\hline 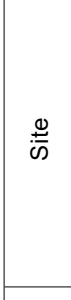 & 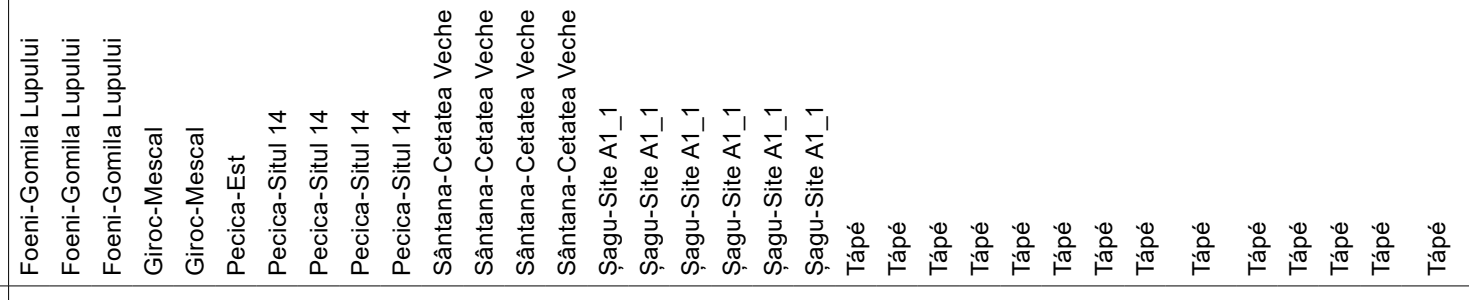 \\
\hline$\stackrel{8}{z}$ & - Nm+b \\
\hline
\end{tabular}


OxCal v4.4.2 Bronk Ramsey (2020): r;5 Atmospheric data from Reimer et al (2020)

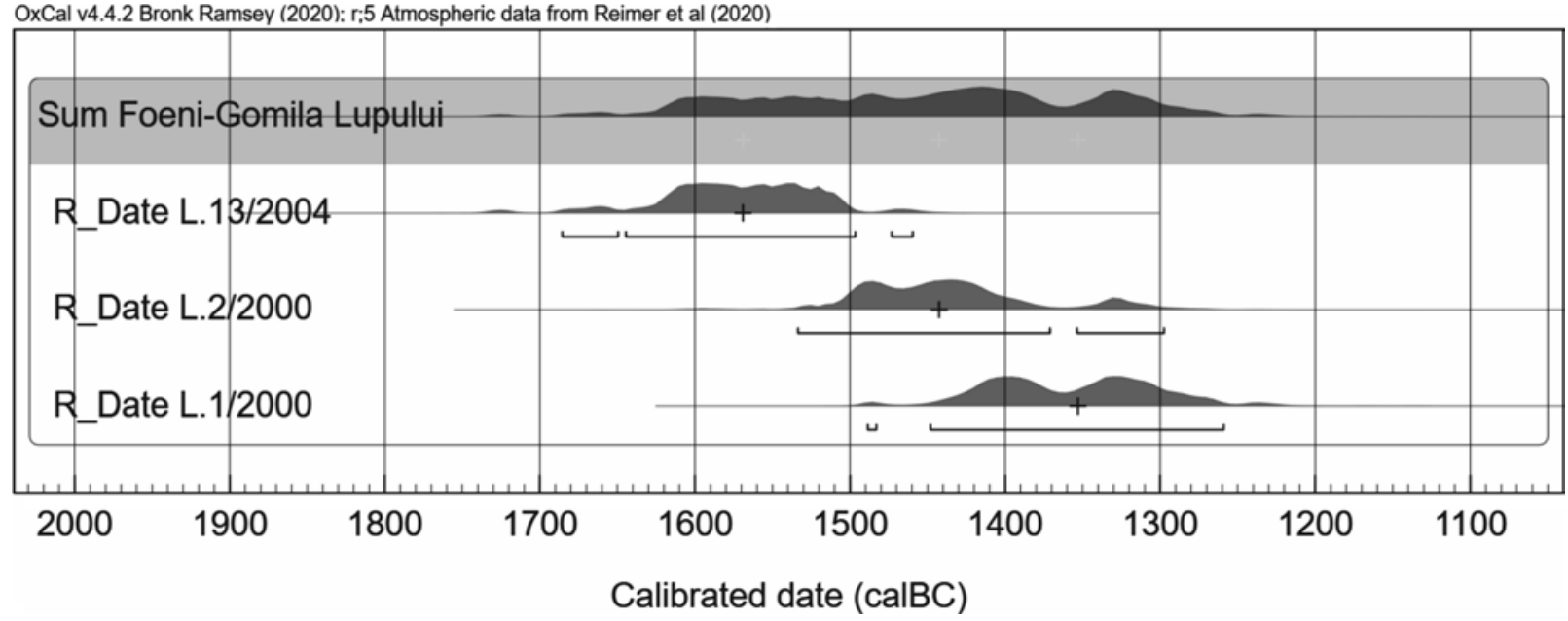

Fig. 6. The calibrated AMS dates from Foeni-Gomila Lupului. Graphic by the author.

in a database that contains fields for recording all the main morphological features of the pottery (shape and decoration) alongside technological properties (decoration techniques). This allowed for the construction of seven query criteria: 1. shapes; 2 . decoration techniques; 3 . association of decoration techniques; 4 . association of shapes and decoration techniques; 5 . ornamental motifs; 6. association of ornamental motifs; 7 . association of shapes and ornamental motifs, all of them being displayed by site, context and absolute dating. This database was designed in order to be updated as soon as new absolute dated contexts are available. For each type and subtype resulted from querying the database using the aforementioned seven criteria, the associated AMS radiocarbon data were then calibrated, mention being made of their sums, and then displayed according to each context that contains the respective types and subtypes. In order to determine the use-period of each type and subtype, the $2 \sigma$ calibrated values were taken into account. At the same time, each query criterion was displayed according to the chronological distribution of each type and subtype and according to their frequency within a limited time span (for example 1500-1400 BC) established through the mean interval of the $2 \sigma$ calibrated value of each AMS date. In order to provide a proper overview of the correlation between pottery evolution and main events (abandonment of tell settlements, construction and destruction of mega-forts), the latter were marked in the tables depicting the chronological distribution of the pottery (Fig. 27; 29; 32; etc.).

\section{The sites and the contexts}

As a direct result of numerous research projects undertaken in the Lower Mureș during the last decades, a considerable number of radiocarbon dates is now available. Unfortunately, only a couple of these dates are associated with a clear find context and pottery assemblages. Therefore, only 34 radiocarbon dates coming from seven sites could be recorded in the database (Fig. 6-15; Tab. 1). Each of these sites will be described in the following paragraphs in alphabetical order, along with the find contexts from where the radiocarbon samples have been taken.

\section{Foeni-Gomila Lupului}

This site was investigated in 1994 by F. Gogâltan, who partially excavated the MBA settlement (Foeni-Gomila Lupului I). In the immediate vicinity of the MBA site, A. Szentmiklosi excavated four trenches and three smaller units during 2000 and 2004, thus discovering a LBA settlement (FoeniGomila Lupului II). Unfortunately, no complete report is available for any of these investigations; therefore, no comment can be made regarding the chronological relation between the two settlements. The excavation campaigns from 2000 and 2004 have led to the discovery of ca. 20-30 LBA features (Szentmiklosi 2009, 209-228). It seems that this settlement can be dated to the time period 1600-1300 BC (Fig. 6), although it is likely that the settlement was established during the MBA, as suggested by the excavation campaign from 1994. The radiocarbon 


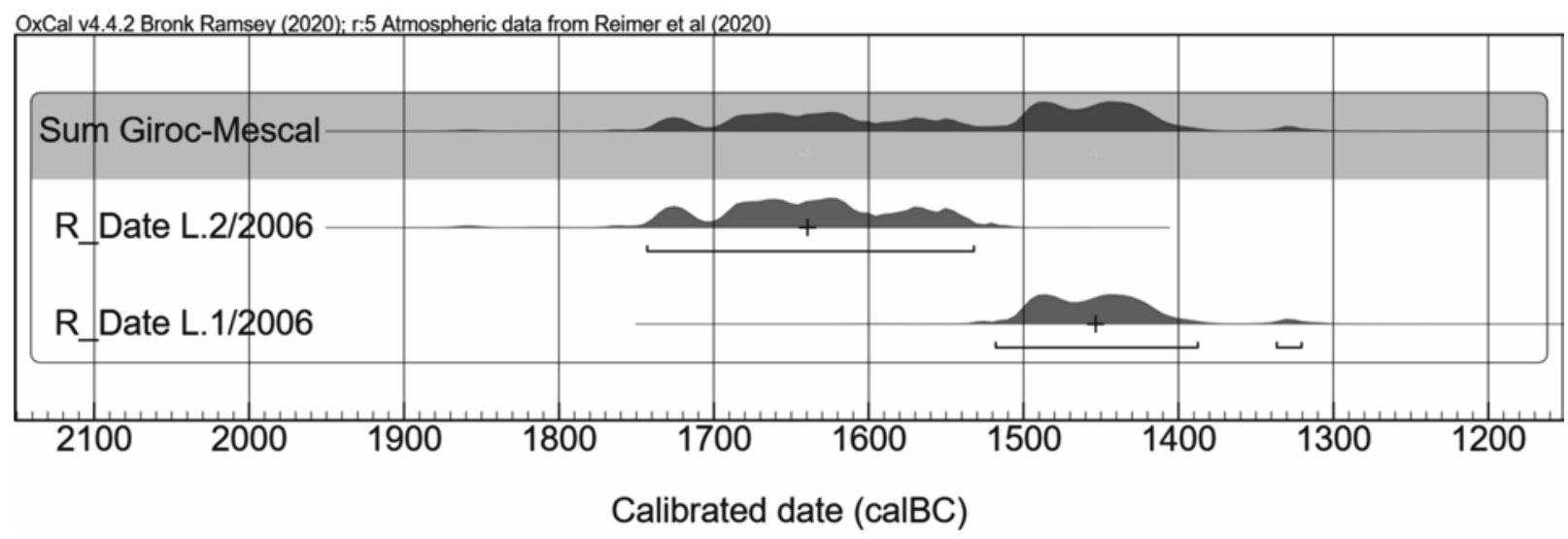

Fig. 7. The calibrated AMS dates from Giroc-Mescal. Graphic by the author.

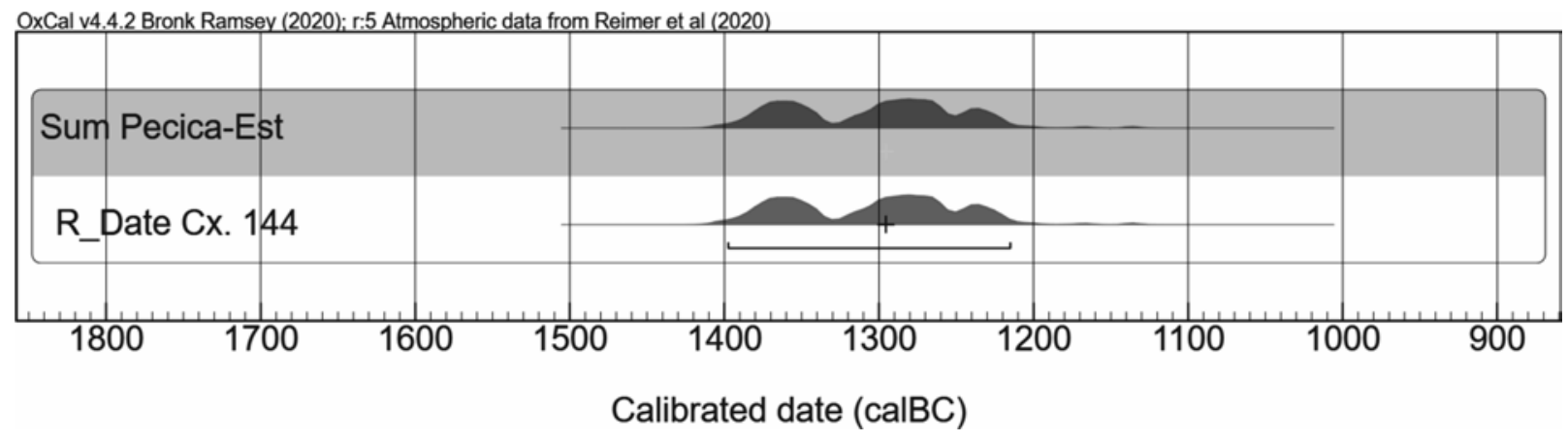

Fig. 8. The calibrated AMS dates from Pecica-Est. Graphic by the author.

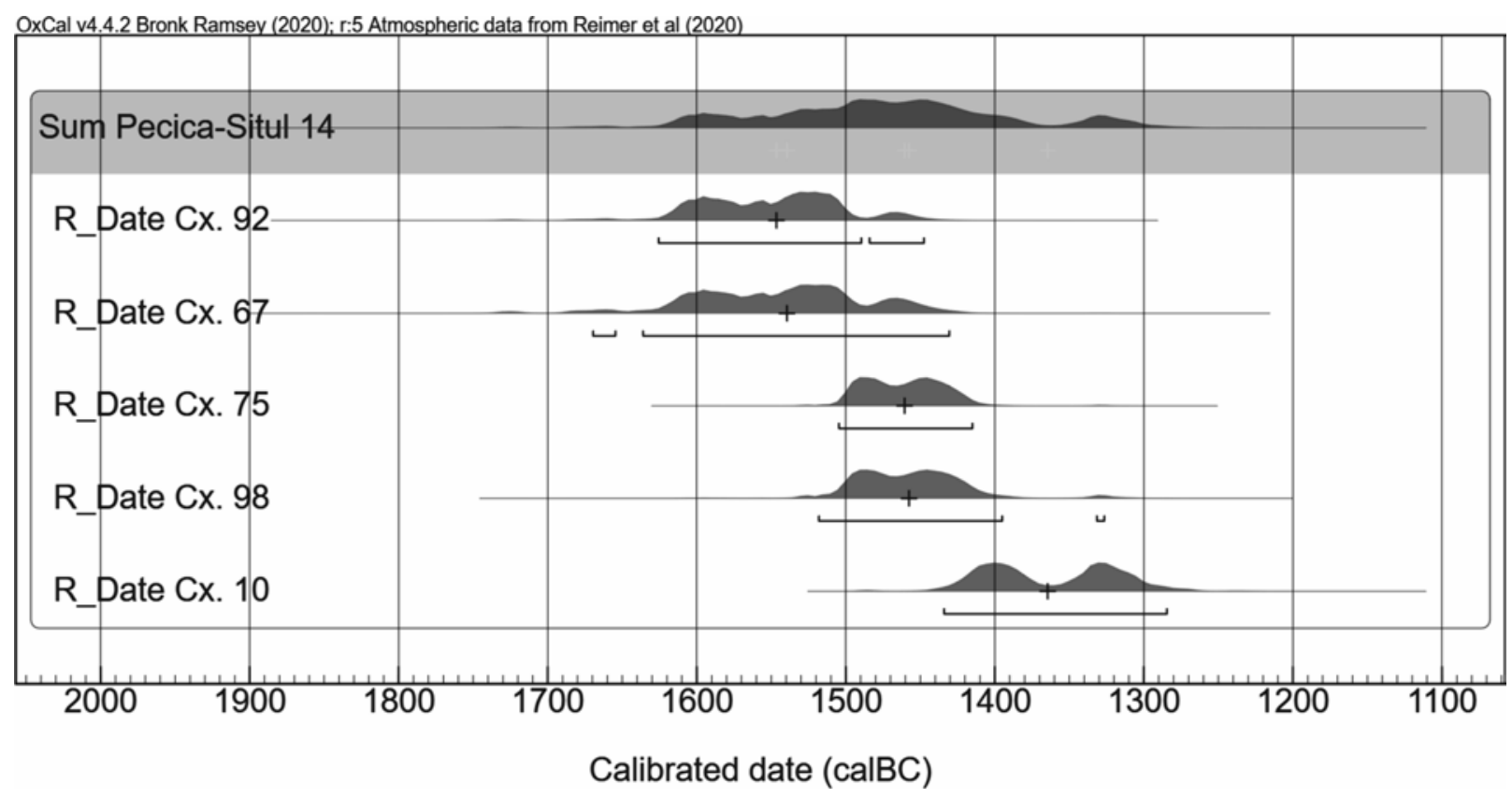

Fig. 9. The calibrated AMS dates from Pecica-Situl 14. Graphic by the author. 
samples (Beta-256557, Beta-256558, and Beta-256559) were taken from large pits that contained a significant amount of pottery sherds, animal bones and daub fragments. Taking into account the fact that all radiocarbon dates from the three mentioned pits at this site are derived from charcoal, an old wood effect should be expected, slightly modifying the dates depicted in Fig. 6.

\section{Giroc-Mescal}

The first investigations undertaken at this settlement were conducted by F. Gogâltan during the 90s' (Gogâltan 1994; Gogâltan/Stavilă 2020), followed in 2006 by an excavation directed by F. Gogâltan and A. Szentmiklosi (Szentmiklosi 2009, 228-234). Given the limited extent of these investigations and the absence of detailed excavation reports, it can only be stated that the two features that were sampled (Beta-256561, Beta-256562) belong to a large time interval, between approximately 1700 and $1400 \mathrm{BC}$ (Fig. 7). Both dates were derived from charcoal samples. The very early date of Beta-256562 (sampled from feature L. 2/2006) is most likely an indication of the old wood effect.

\section{Pecica-East}

This site was discovered in 2015, between 2015 and 2017 an area of 13,800 $\mathrm{m}^{2}$ was excavated during several campaigns, leading to the discovery of numerous features dating to different periods (Saval Mărginean/Ursuțiu 2017). Among these features there were three pits that contained LBA pottery. It should also be pointed out that the discoveries coming from the investigated area are close to the relatively contemporary settlements from PecicaSite 15 (Marta et al. 2012) and Pecica-Forgaci. The radiocarbon date RoAMS 996.80 (Fig. 8) was taken from pit Cx. 144 that contained numerous pottery sherds and animal bones.

\section{Pecica-Site 14}

Investigations conducted over an area of $7762 \mathrm{~m}^{2}$ have led to the discovery of 38 graves, out of which 24 were inhumation graves and 14 were cremation graves (Ignat/Sava 2019, 7, 8, fig. 3; 5; 6; 8; 10; Saval Andreica 2013; Sava/Ignat 2014, 7-16, fig. 1-7; 2016, 185, 186, fig. 4-7). Grave goods in the inhumation graves consisted of bronze objects (weapons - daggers, axes and ornaments - bracelets, pins, ornamental disks), amber artefacts and pottery (the typical assemblage consisted of one pot and one or two cups). Children and adolescent graves were the most richly furnished in terms of number and type of grave goods. The cremated remains along with few grave goods were placed in large urns; in almost all cases a cup or a dish had been placed either inside the urn or underneath it; some of the burials were also provided with bronze artefacts, mostly ornaments such as bracelets or different types of loops. The available data indicate that the inhumation graves can be dated between 1600 and 1300 BC (Fig. 9), but the cemetery could have a later phase composed of cremated burials. Although inhumation is the predominant burial rite at the site, cremation graves could be documented throughout the entire lifespan of the cemetery.

Up to the present moment five graves have been dated; the funerary assemblage of one of these graves consisted solely of bronze artefacts (Cx. 75) and therefore could not be included in the present analysis. The graves Cx. 67, Cx. 92 and Cx. 98 along with their grave goods have been described in detail in earlier publications (Sava/Ignat 2014, 7-16, fig. 1-7). Besides these burials, another inhumation grave (Cx. 10) whose funerary assemblage also consisted of two pottery vessels has been sampled (RoAMS 988.80).

\section{Sântana-Cetatea Veche}

The fortification from Sântana has been thoroughly investigated in the last years through excavations, geophysical surveys, LIDAR scanning, etc. (Gogâltan/Sava/Krause 2019; Krause et al., in press; Saval Gogâltan/Krause 2019). The available data indicate that the mega-fort consisting of four fortification systems extending over an area of approximately 130 ha was erected during the $15^{\text {th }} \mathrm{c}$. BC and was subsequently destroyed at the end of the $14^{\text {th }} \mathrm{c}$. BC, or latest in the first part of the $13^{\text {th }} \mathrm{c}$. BC (Fig. 10). By far the most impressive fortification system from Sântana is the third one that consists of a rampart made of earth, wood and stone having a width of almost $27 \mathrm{~m}$ and a height of $2.5 \mathrm{~m}$ on top of which a timber-and-daub wall was erected, and two large ditches. No less than 29 rather large structures have been identified through geophysical surveys, most of them located within the first enclosure. Several lines of evidence such as the destruction of the fortification systems, the numerous weapons found among the debris of enclosure III and the discovery of human skeletal remains within the fills of the ditches (some of them displaying evidence of trauma) indicate that latest in the first half of the $13^{\text {th }} \mathrm{c}$. the fortification suffered a siege and was burned down.

Of special note is the abundance of gold and bronze artefacts at the site. At the same time, the discovery of glass and faience beads and graphite pottery points towards the orientation of the trade 


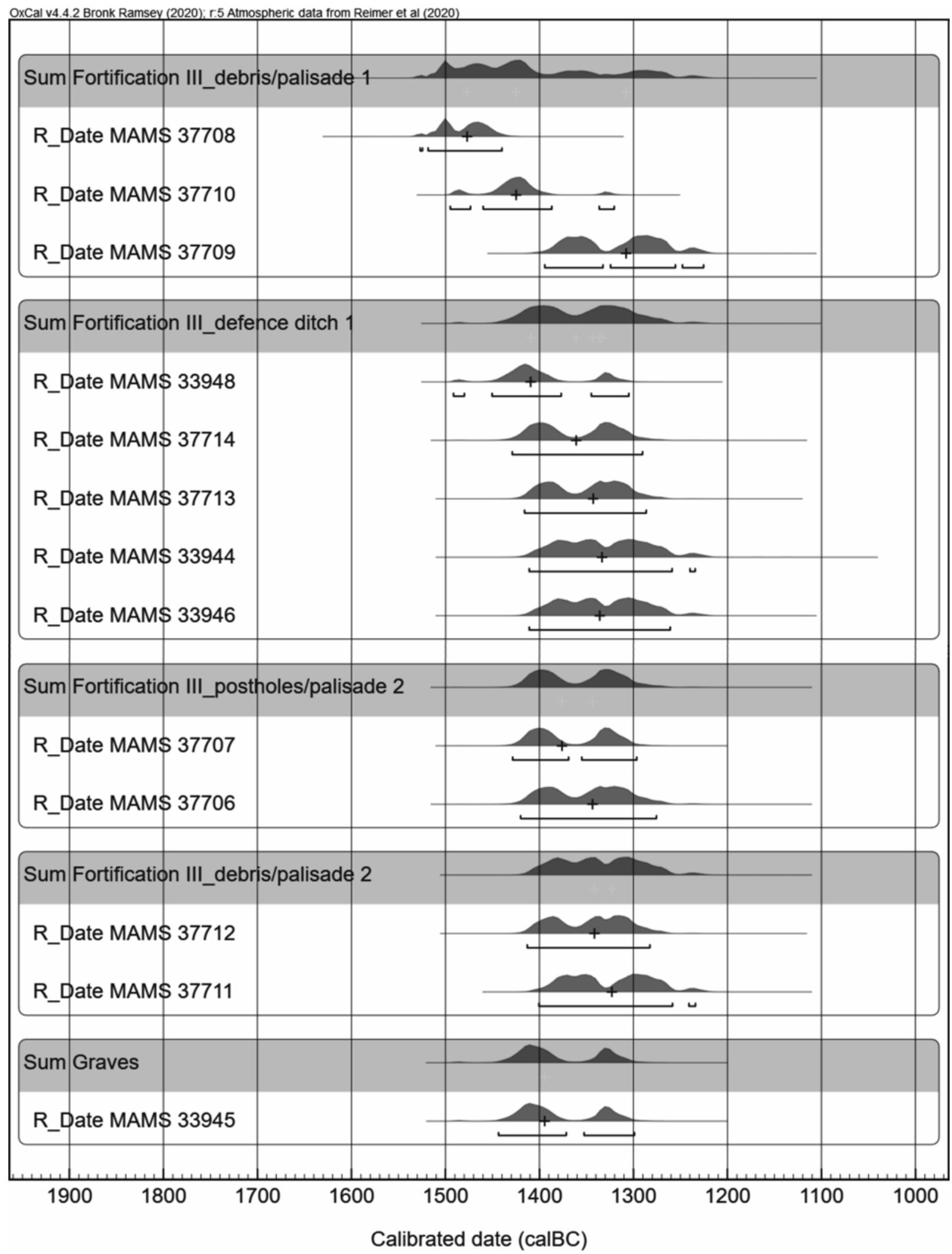

Fig. 10. The calibrated AMS dates from Sântana-Cetatea Veche. Graphic by the author. 


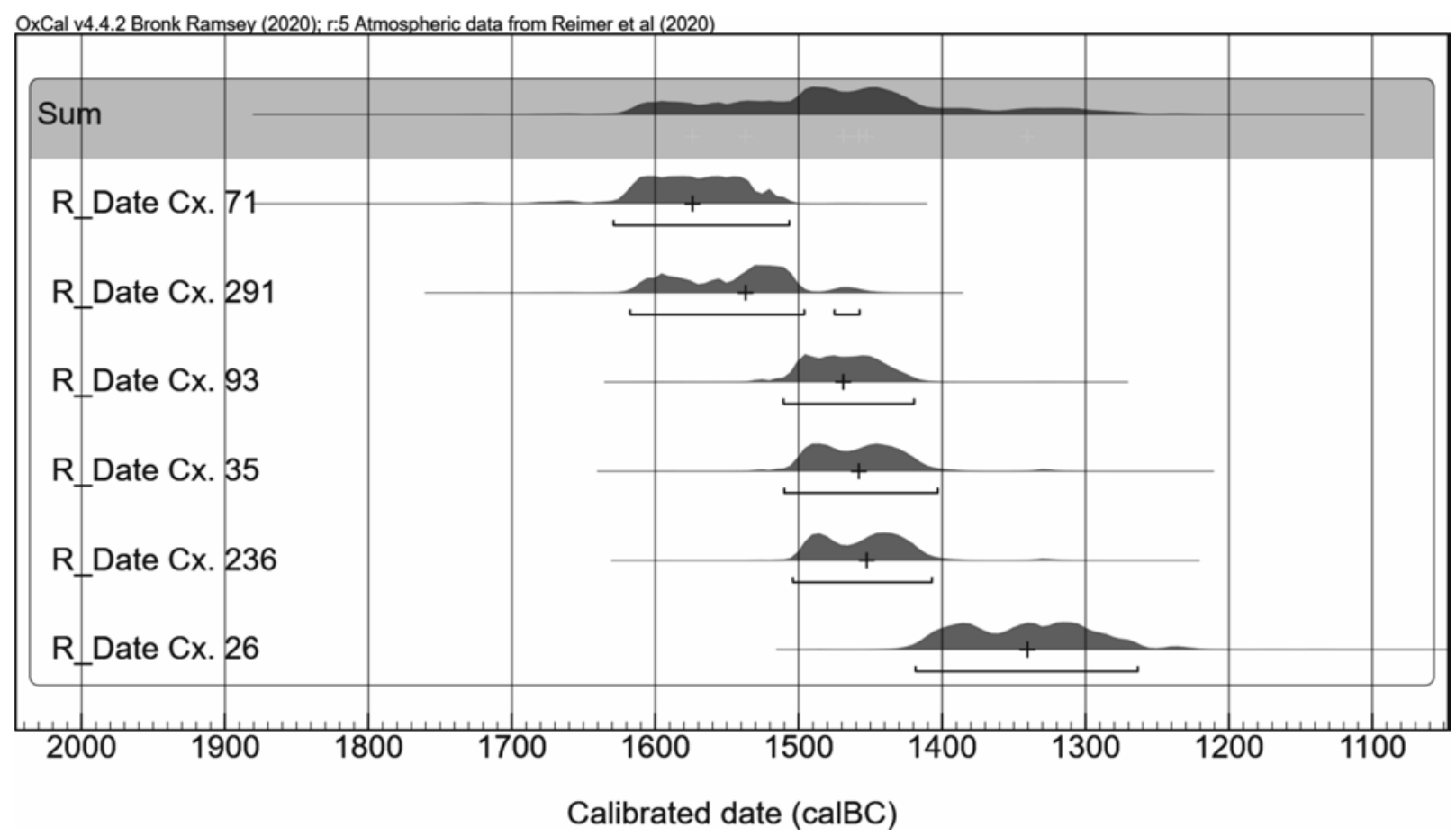

Fig. 11. The calibrated AMS dates from Șagu-Situl A1_1. Graphic by the author.

routes that secured the acquisition of raw materials and prestige goods. Of course, pottery is the most abundant category of finds at the site. Due to the site's characteristics, most of the resources were targeted towards investigating the fortification system. This is why for this study only the pottery that could be associated with secure contexts was analysed. Reference is being made here to the pottery uncovered within grave CX 41/S1 from where the sample MAMS-33945 was taken, and to the two vessels found in the fill of the ditch Cx. 38/S1 (sample MAMS-33948); both these features have been described in detail elsewhere (Sava/Gogâltan/ Krause 2019, 164-170, fig. 5; 9). The pottery unearthed from the debris of the second palisade belonging to enclosure III (Cx 5/S5; samples MAMS-37711; MAMS-377120) has also been included in the database (Gogâltan/Sava/Krause 2019, 203-209, fig. 12-20; tab. 1). The dates for the second palisade belonging to enclosure III are similar to the absolute dates retrieved from the fill layers of ditch 1 , a fact that indicates that a short amount of time elapsed between the construction of palisade 2, the filling of ditch 1 and the destruction of the fortification, all these event taking place during the $14^{\text {th }} \mathrm{C}$. BC, or in the first decades of the $13^{\text {th }} \mathrm{c}$. BC at the latest.

\section{Şagu-Site A1_1}

The settlement from Șagu-Site A1_1 stands out among the many LBA sites from the Lower Mureș.
The site is located in the high Vinga plain, at the foothills of the Carpathian Mountains. Although the settlement is known since the 1980s', extensive excavations were only undertaken in 2010 (Saval Hurezan/Mărginean 2011). Surface surveys indicate that the site originally extended over an area of about $23 \mathrm{ha}$. Within the $28,800 \mathrm{~m}^{2}$ excavated area a number of 306 LBA features have been identified. The available radiocarbon dates indicate that the settlement was established during the $16^{\text {th }} \mathrm{c}$. BC and continued to be in use until the $14^{\text {th }} \mathrm{c}$. BC, or first half of the $13^{\text {th }} \mathrm{c}$. BC (Fig. 11). Although most of the uncovered artefacts are indicative of various domestic activities being undertaken at the site, there are also finds that point towards animal rearing, activities related to the secondary use of animal products (Sava V. 2014) as well as pottery production. Perhaps one of the most salient features of the settlement's economy is reflected by the abundance of metalworking debris at the site. Evidence of metalworking has been unearthed in several pits of various shapes and sizes located within the settlement (Sava/Hurezan/ Mărginean 2012). Although evidence of metalworking has been uncovered from the earliest phases of occupation at the site, most of the metalworking debris dates to the $15^{\text {th }}$ and $14^{\text {th }} \mathrm{c}$. BC.

The radiocarbon dates have been taken from six features, which most likely cover the entire lifespan of the settlement. The inventory of these pits consisted of several artefacts and numerous pottery sherds. 


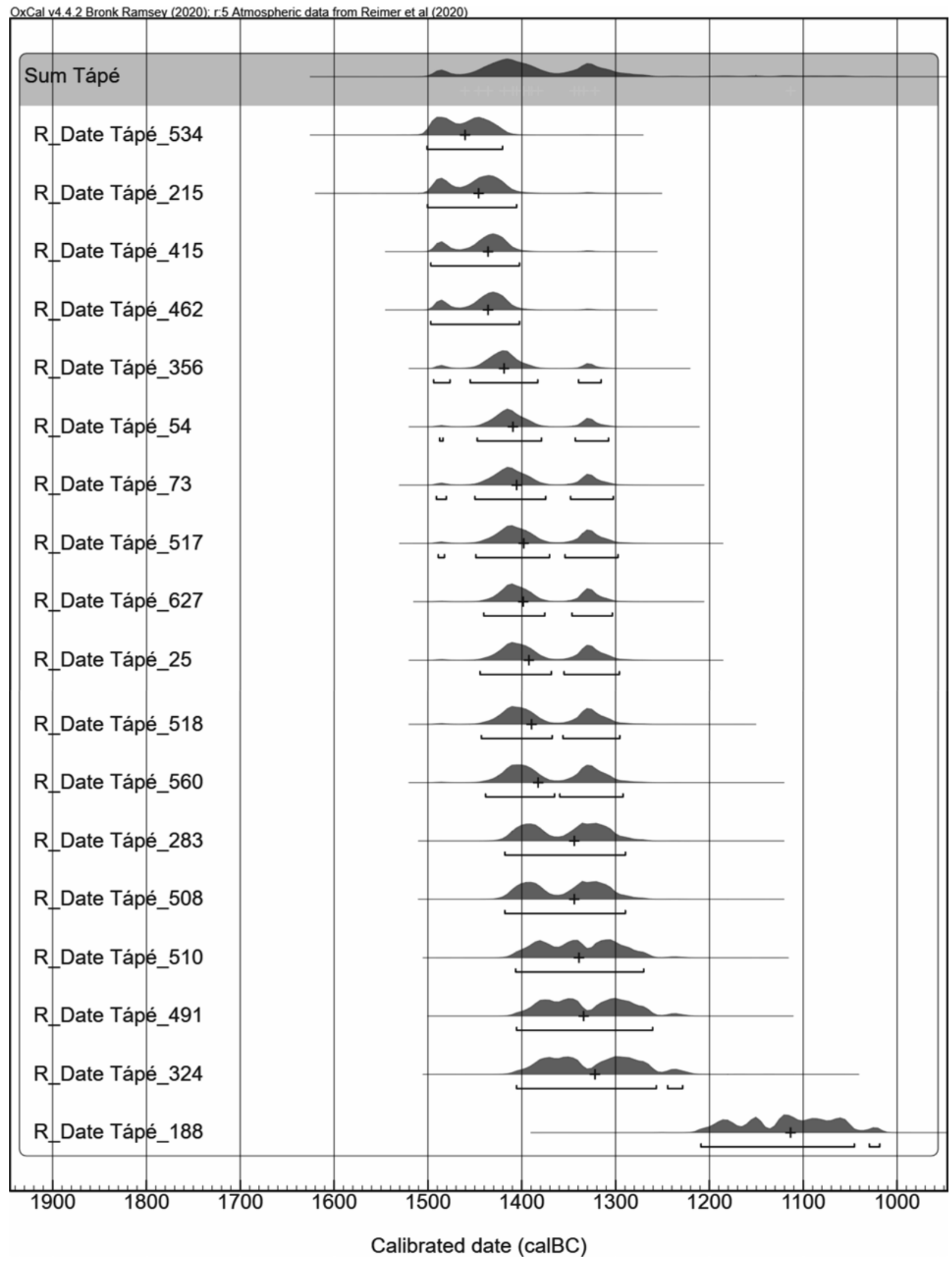

Fig. 12. The calibrated AMS dates from Tápé. Graphic by the author. 


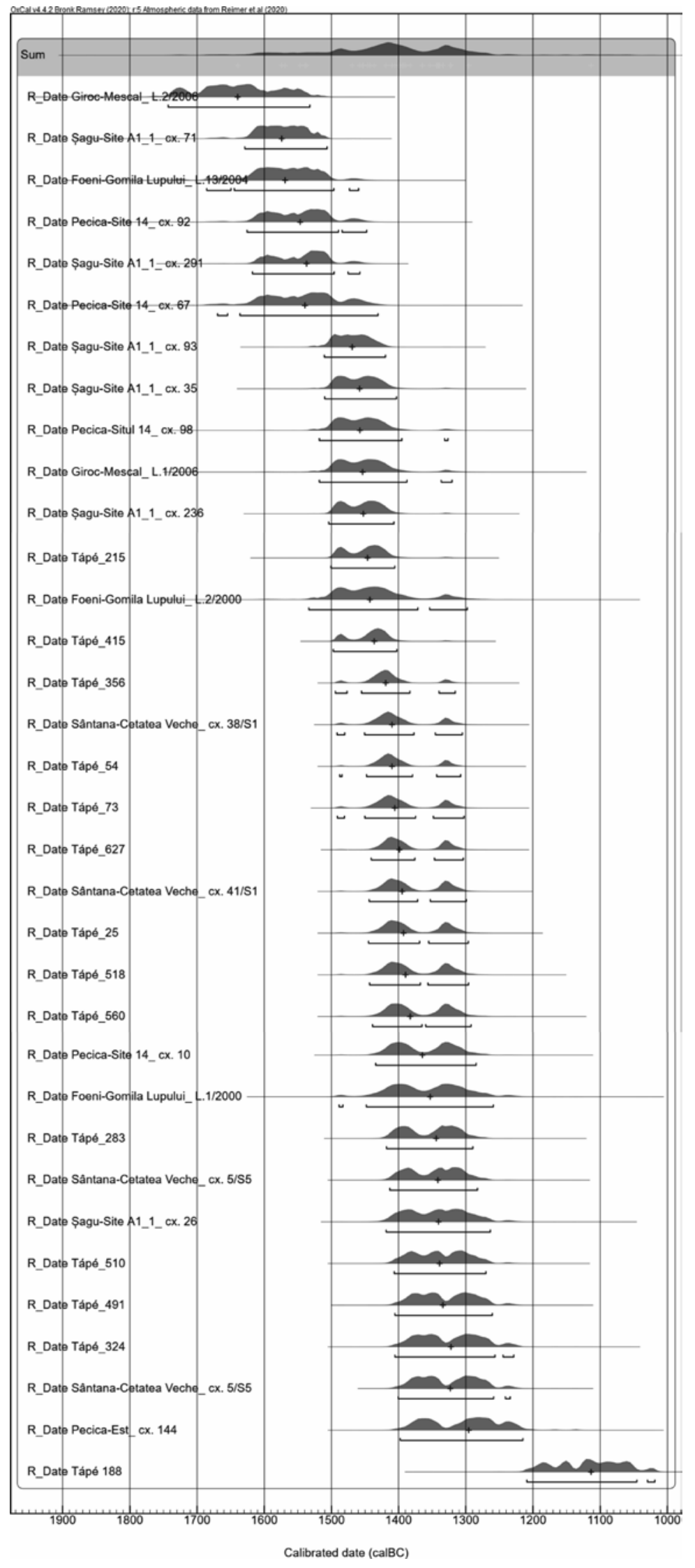

Fig. 13. The calibrated AMS dates coming from the analysed features. Graphic by the author.

\section{Tápé-Széntéglaégető}

Due to its considerable size and the fact that the results of the excavations undertaken here in the 1960s have been published in detail (Trogmayer 1975), this cemetery is undoubtedly a reference point for the LBA in the inner Carpathian region. Out of the 687 uncovered burials only a small percentage are cremation graves, while the rest are inhumation graves that continue a MBA tradition. The social characteristics resulting from the analysis of the combination of various grave goods have been already discussed in detail (Blischke 2002, 51-153); radiocarbon samples taken from 18 graves indicate that the cemetery was in use between approximately 1500 and 1250 BC (Fig. 12; O'Shea et al. 2019, fig. 5; tab. 3). It can be assumed that the cemetery was also used, albeit only infrequently, during the $12^{\text {th }}$ and $11^{\text {th }}$ centuries BC, as suggested by the date retrieved from grave 188.

\section{RESULTS}

According to the traditional relative chronology that for a long time was the only common denominator for all the different areas of the wider inner Carpathian region, the beginning of the LBA, or the appearance of the Cruceni-Belegiš I, Noua, Lăpus, etc. pottery styles, was set around 1300 BC (Ciugudean 2010, fig. 4). After a decade of excavations in important LBA sites and the collection and publication of a considerable number of radiocarbon dates, the beginning of the LBA (as defined in most publications on the subject) is set much earlier (Gogâltan 2019, 48-51; Sava/Gogâltan 2019; Sava/Ignat 2016, 192-195). These opinions are confirmed by the new radiocarbon dates coming from the Lower Mureș that so far indicate that the LBA starts in this region in the $16^{\text {th }}$ c. BC (Fig. 13-15). During LBA I, new settlements are being established in the region: Giroc-Mescal, ȘaguSite A1_1, Foeni-Gomila Lupului, for 
a short period of time, the aforementioned sites are contemporary with the last phase of occupation on some MBA tells from the region such as PecicaȘanțul Mare (Nicodemus/Motta/O'Shea 2015, tab. 1) and Klárafalva-Hajdova (O'Shea et al. 2019, fig. 8). All the aforementioned LBA settlements continue their existence during LBA II, when the mega-fort in Sântana-Cetatea Veche is constructed. The end of LBA II and the beginning of LBA III coincides with the destruction of the Sântana mega-fort, this time interval also being obtained after analysing the sum distribution of the calibrated dates and with the boundary end of the sequence depicted by the calibrated dates, with the exception of UGAMS 30830 (Tápé 188).

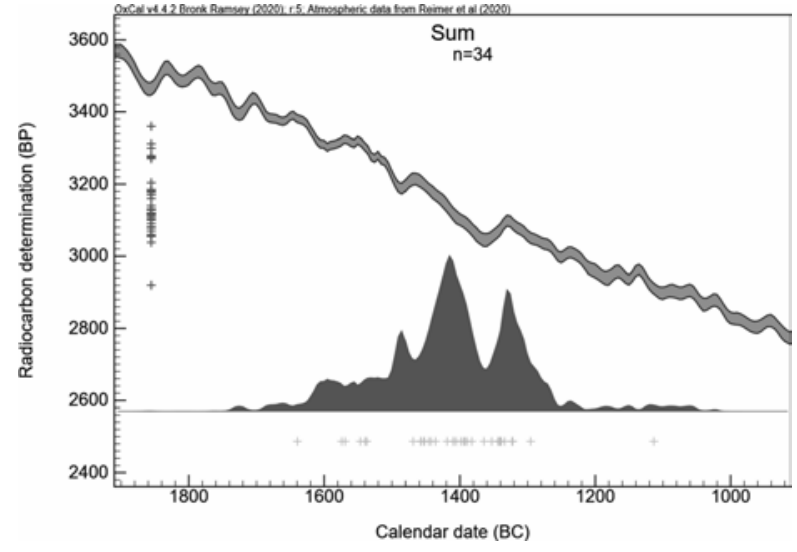

Fig. 14. The sum of the AMS dates coming from the analysed features. Graphic by the author.

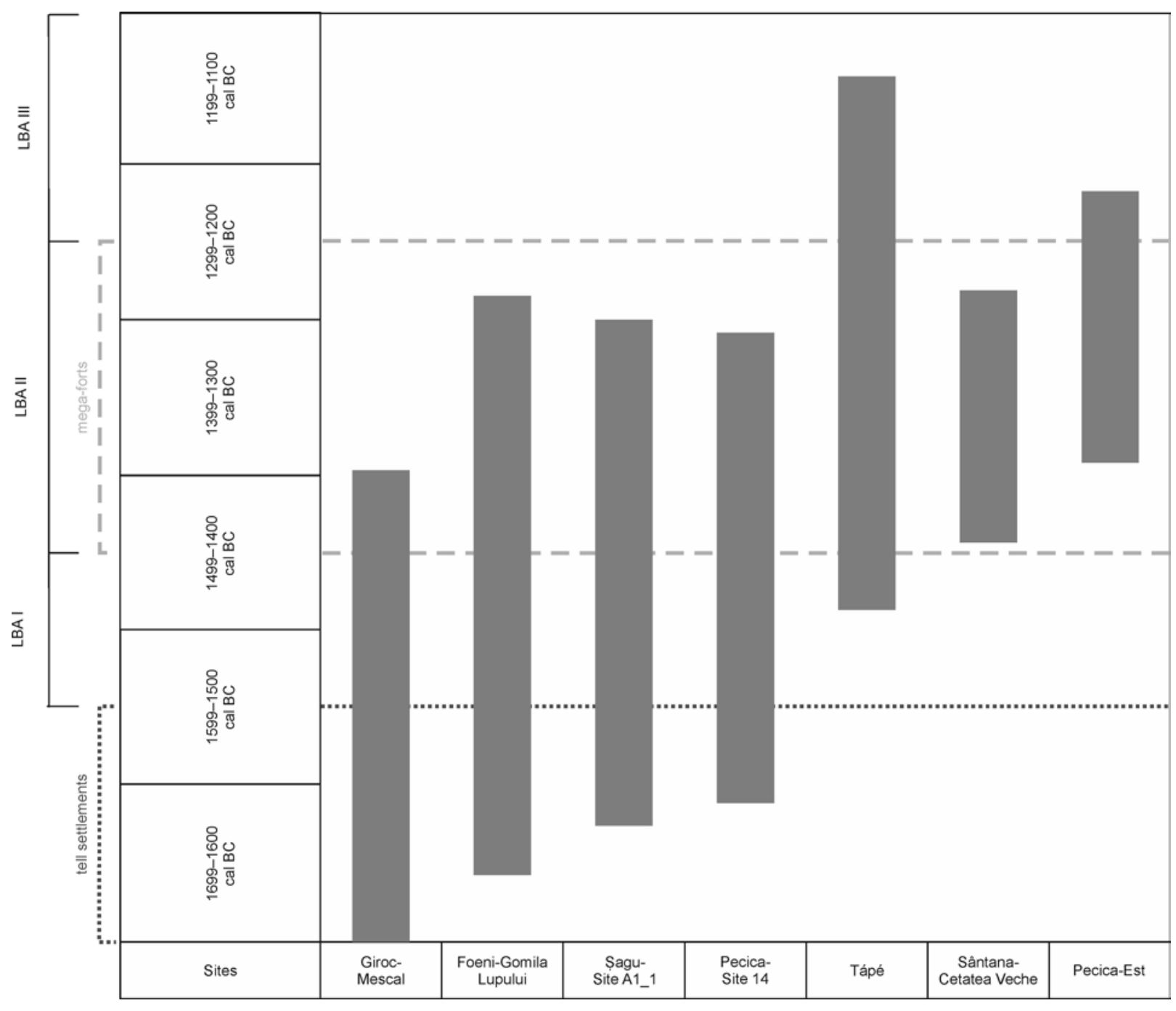

Fig. 15. Chronological evolution of the sites mentioned in the analysis. Graphic by the author. 
Tab. 2. List of the pottery forms (Fig. 16).

\begin{tabular}{|c|c|}
\hline Types & Subtypes \\
\hline 1. Dishes & $\begin{array}{l}\text { 1A. Dish with straight rim (of reduced size) } \\
\text { 1B. Low dish with biconical body } \\
\text { 1C. Dish with biconical body } \\
\text { 1D. Dish with biconical body and a short neck } \\
\text { 1E. Dish with lobed rim } \\
\text { 1F. Biconical dish with small lobes on the rim } \\
\text { 1G. Dish with straight rim (of a large size) } \\
\text { 1H. Dish with inverted rim } \\
\text { 1I. Dish in the shape of a truncated cone } \\
\text { 1J. Large dish with S-shaped profile }\end{array}$ \\
\hline 2. Cups & $\begin{array}{l}\text { 2A. Cup with flared rim, short neck, low globular body and straight base } \\
\text { 2B. Cup with globular belly and a handle reaching up to the rim } \\
\text { 2C. Cup with a globular body, wide mouth and a handle rising slightly above the rim } \\
\text { 2D. Small cup with a globular body, umbo-shaped base and a handle rising slightly } \\
\text { above the rim } \\
\text { 2E. Cup with slightly flaring rim, long and straight neck, narrow biconical belly and } \\
\text { a straight base } \\
\text { 2F. Cup with a straight rim, globular, slightly biconical body and foot } \\
\text { 2G. Cup with a globular belly, ringed base and wide mouth }\end{array}$ \\
\hline 3. Pots & $\begin{array}{l}\text { 3A. Pot with constricted neck } \\
\text { 3B. Pot with wide mouth and biconical body } \\
\text { 3C. Pot with globular belly and slightly flaring rim }\end{array}$ \\
\hline 4. Biconical vessels & $\begin{array}{l}\text { 4A. Low biconical vessel with wide mouth and flaring rim } \\
\text { 4B. Vessel with two small handles, tall and slender neck, biconical body and flat base } \\
\text { 4C. Vessel with a straight mouth, tall neck, biconical body and flat base }\end{array}$ \\
\hline 5. Footed biconical vessels & - \\
\hline $\begin{array}{l}\text { 6. Large biconical vessels with flaring rim, biconical } \\
\text { body and flat base }\end{array}$ & - \\
\hline $\begin{array}{l}\text { 7. Vessel with slightly flaring rim, short neck, long } \\
\text { and slightly biconical body and flat base }\end{array}$ & - \\
\hline 8. Trays & - \\
\hline 9. Lids & - \\
\hline
\end{tabular}

\section{Pottery shapes}

The typological analysis of the pottery assemblage here under study has revealed that only for $25.36 \%$ of the sherds (140 items) could the original shape be reconstructed. A total of nine main shapes could be identified, which were further divided in 23 subtypes (Fig. 16; Tab. 2). By correlating the chronological distribution of the pottery shapes with the main historical events in the Lower Mureș (the abandonment of tell settlements, the construction of mega-forts, etc.) and the three phases of the relative chronology (LBA I, II and III) we can gain an overview of the connection between these main events and the emergence or disappearance of certain pottery shapes (Fig. 17). While certain shapes such as some dishes $(1 \mathrm{~A}, 1 \mathrm{~F})$, pots $(3 \mathrm{C})$ or biconical vessels $(4 \mathrm{~A})$ seem to be in use for only a limited amount of time, other shapes such as dishes 1D and $1 \mathrm{E}$ along with the large biconical vessels 6 were used for a long period of time. There are certain types and subtypes, such as dishes of the type $1 \mathrm{~B}$ and $1 \mathrm{C}$, cups belonging to the type $2 \mathrm{~A}$, biconical vessels of the types $4 \mathrm{~B}$ and $4 \mathrm{C}$ or lids belonging to 


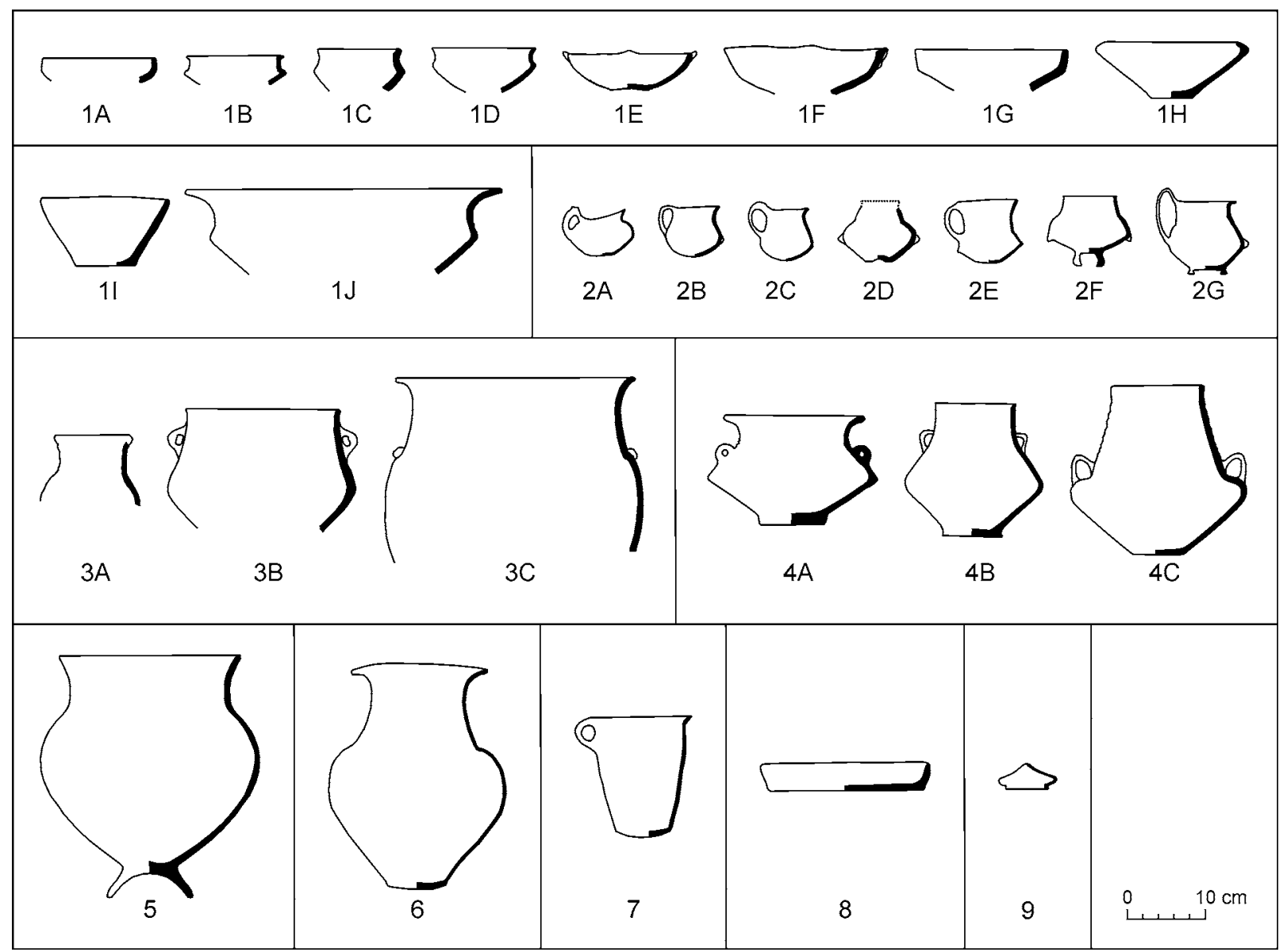

Fig. 16. Typological table of pottery shapes. Graphic by the author.

type 9 that can be correlated with the phase LBA II. Although the chronological distribution of certain types of vessels is very relevant for this discussion, much more important is the frequency in which these types and subtypes are found within specific time frames (Fig. 18). Thus, even if the subtype 1D seems to be in use for a very long period of time, it is most frequently encountered between 1500 and $1300 \mathrm{BC}$; the same is true for subtype 1E whose most frequent use is limited to the period between 1500 and 1400 BC. At the same time, shapes such as $1 \mathrm{H}$ or 6 have a constant frequency throughout their rather short interval of use that lies mostly between 1500 and 1300 BC. In certain instances, by combining the absolute chronology with the frequency of shapes, we can identify shapes that were specific to a certain time frame; for example, dishes of the $1 \mathrm{E}$ and $1 \mathrm{G}$ types, cups belonging to the type $2 \mathrm{G}$ and biconical vessels of the $4 \mathrm{~A}$ type are shapes characteristic for the period between 1600 and $1400 \mathrm{BC}$, while the dishes belonging to the types $1 \mathrm{E}$ and $1 \mathrm{I}$, the cups of the $2 \mathrm{~B}$ type and the biconical vessels of type $4 \mathrm{C}$ are characteristic for the period 1500-1400 BC.

\section{Pottery decoration techniques}

Five main decoration techniques could be identified on the analysed pottery: incision (1), channelled decoration (2), pseudo-twisted cord (3), embossed decoration (4) and impression (5). Incised, channelled and embossed decorations are the most frequently used techniques, while impressions and pseudo-twisted cord decoration are seldom employed. Pseudo-twisted cord decoration can only be encountered on pottery coming from Giroc-Mescal and Foeni-Gomila Lupului. It is noteworthy that all five decoration techniques span the entire LBA I and II. Thus, better results can be obtained by combining the chronological distribution of decoration techniques with their use frequency (Fig. 19; 20). As a result, both general patterns in the development of decoration techniques and specific aspects of a certain limited chronological sequence could be identified. By correlating these findings with the main events from the region, it can be easily noticed that after 1400 BC (a time period that corresponds to the emergence and evolution 

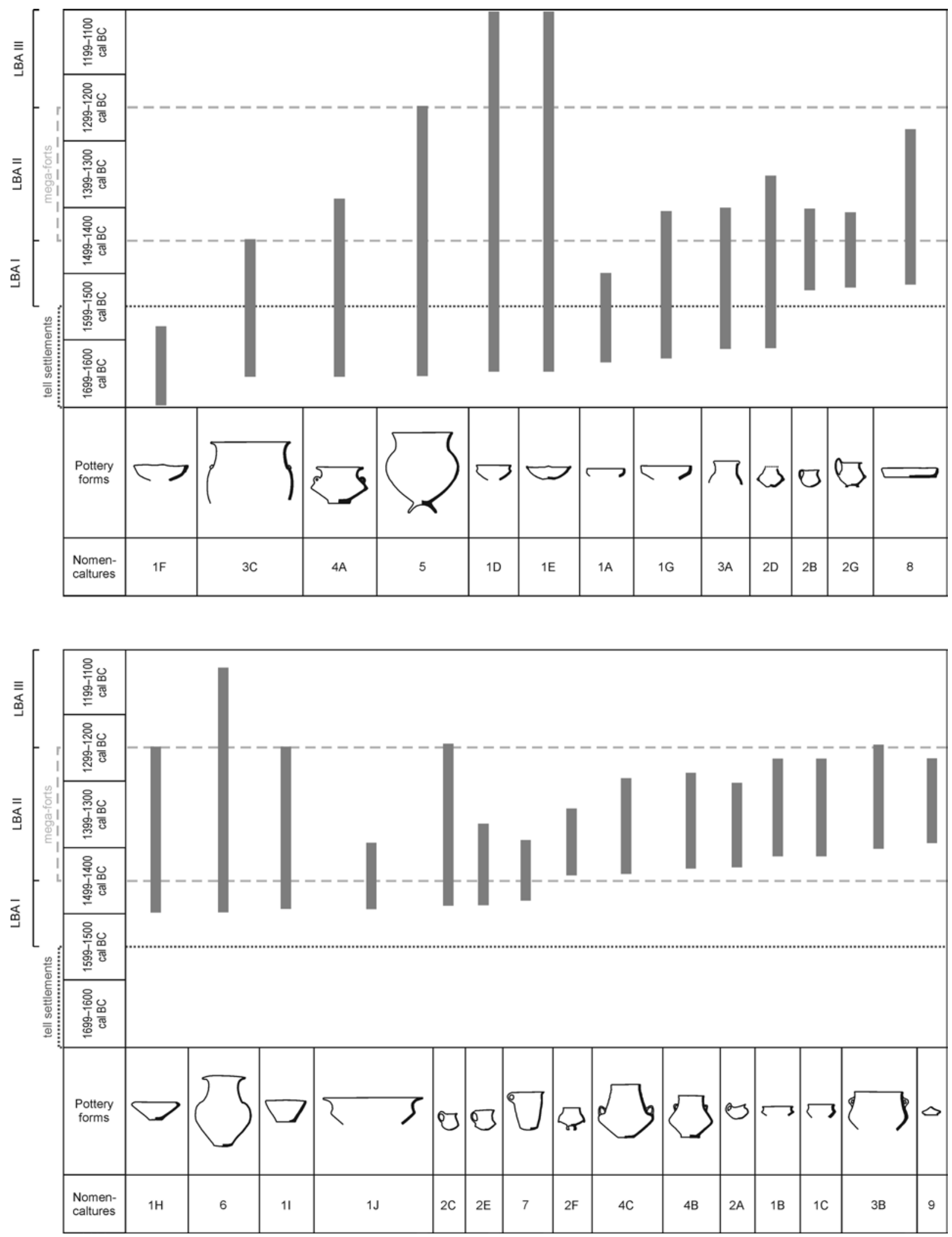

Fig. 17. Chronologic distribution of pottery shapes. Graphic by the author. 


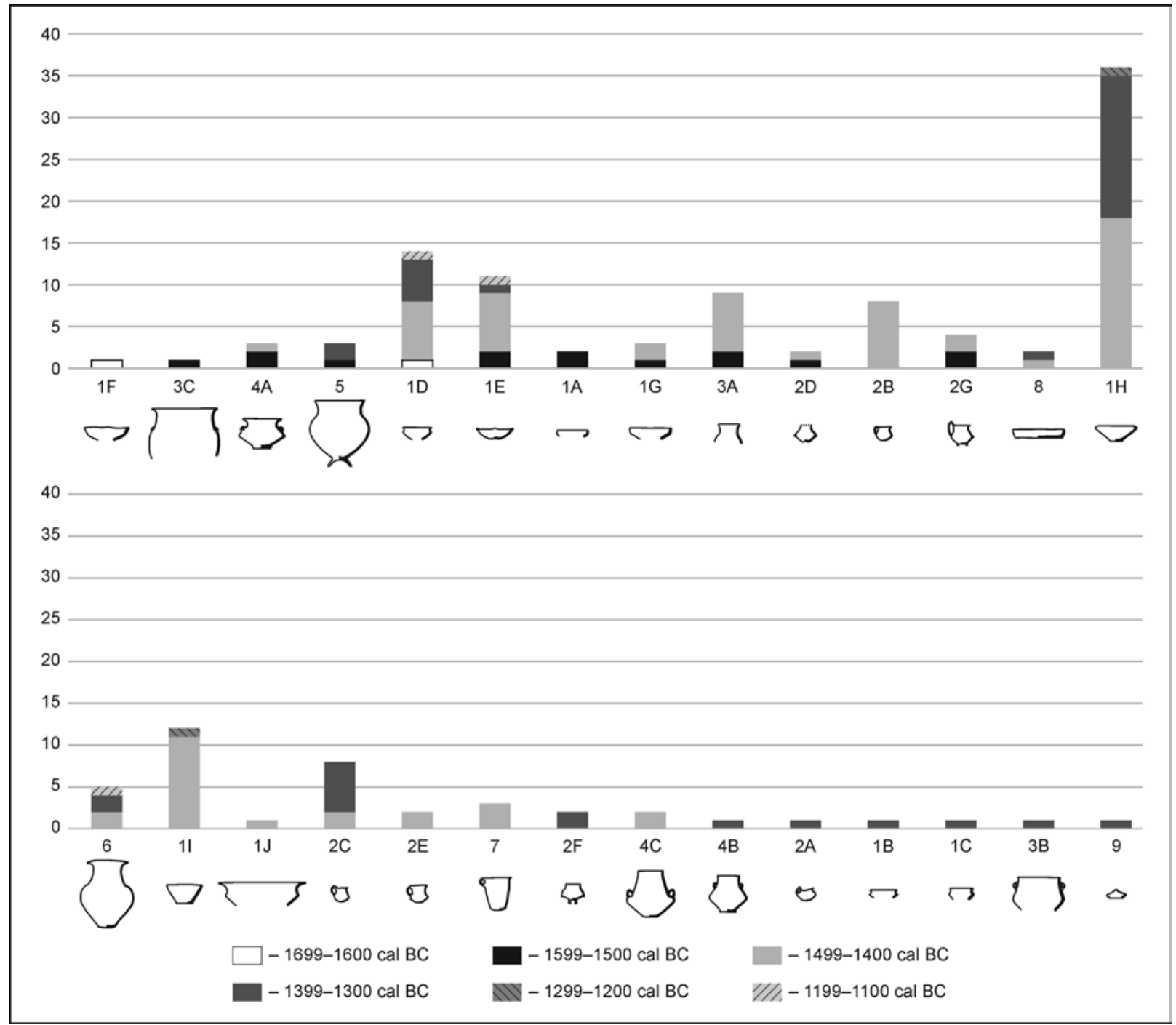

Fig. 18. Chronologic distribution of pottery shapes and their frequency. Graphic by the author.

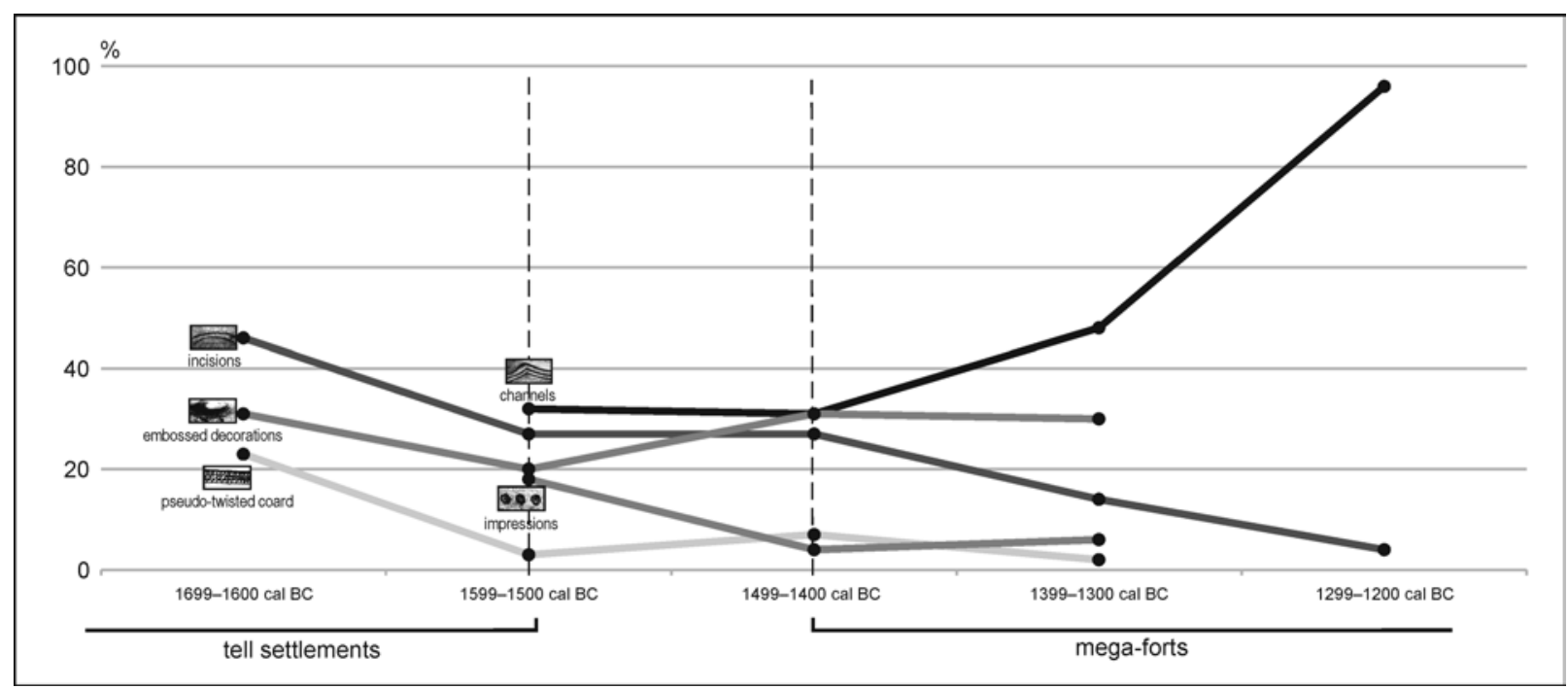

Fig. 19. Chronologic distribution and frequency of pottery decoration techniques. Graphic by the author. 


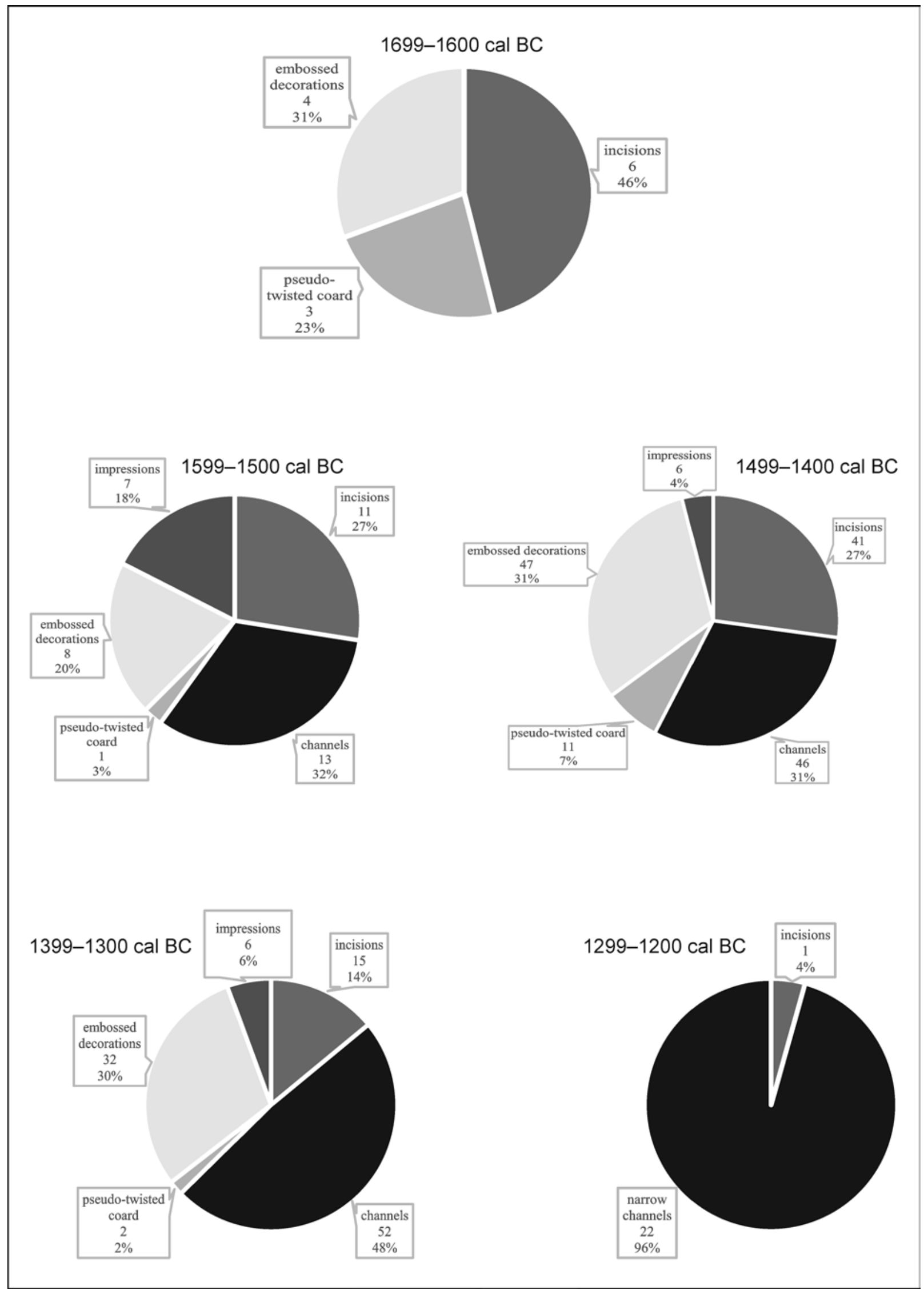

Fig. 20. Chronologic distribution and frequency of pottery decoration techniques over the centuries. Graphic by the author. 


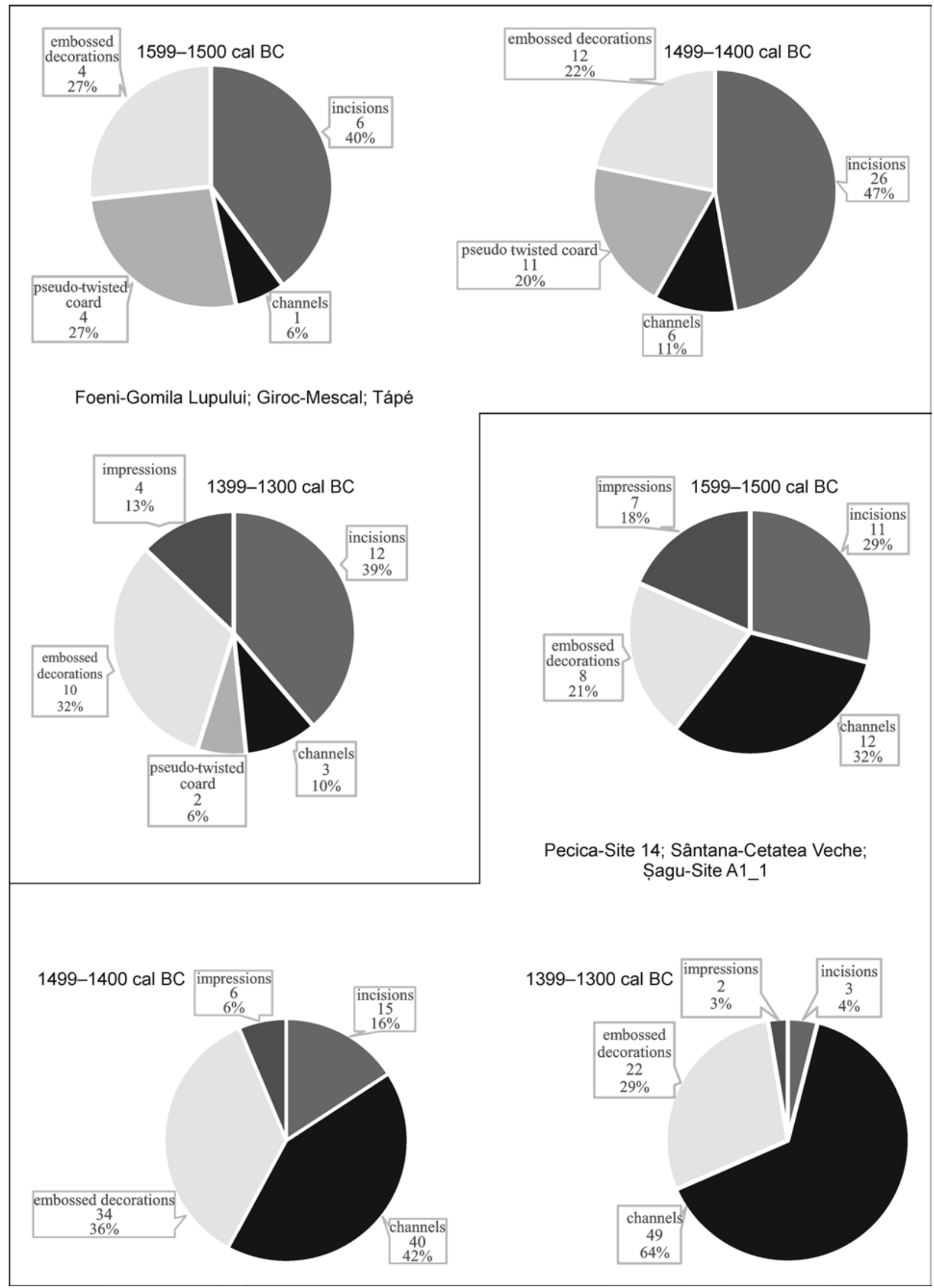

Fig. 21. Chronologic distribution and frequency of pottery decoration techniques over the centuries displayed according to the two groups of sites. Graphic by the author. 


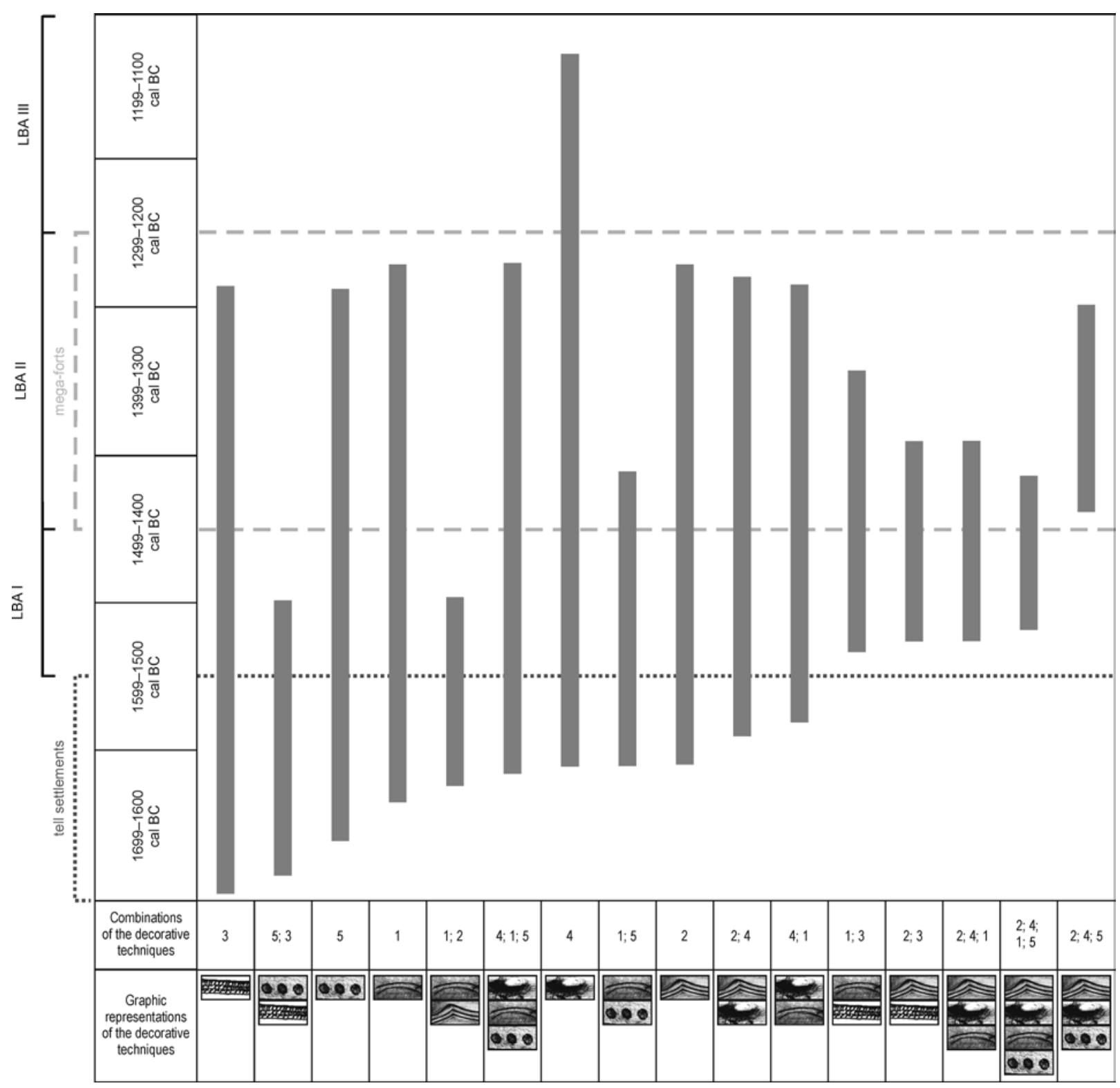

Fig. 22. Chronological distribution of the association of pottery decoration techniques. Graphic by the author.

of mega-forts), channelled decoration becomes the dominant decoration technique at the expense of incised decoration. Furthermore, the fact that there are more vessels with channelled decoration than vessels bearing incised decoration in most early contexts (approximately 1600-1400 BC) raises serious questions regarding the traditional relative chronology schemes that assign incised decoration an earlier date and channelled decoration a later date.

By sorting the decoration techniques according to archaeological sites and the three main time periods represented in our study, it can be noted that the sites cluster in two groups (Fig. 21). The first group entails the sites from Foeni-Gomila Lu- pului, Giroc-Mescal and Tápé. Incised decoration is clearly prevalent among the analysed contexts from these three sites, while pseudo-cord decoration is only found at Foeni and Giroc; furthermore, channelled decoration is seldom on pottery belonging to this group. On the other hand, within the second group (that consists of the sites from Pecica-Site 14, Sântana-Cetatea Veche and Șagu-Site A1_1) channelled decoration is the predominant decoration technique as early as the time period $1600-1500 \mathrm{BC}$, while between 1400 and 1300 BC over $60 \%$ of the analysed pottery has channelled decoration. As a result of the undertaken analysis, two major preferences regarding pottery decoration techniques can be observed in the Lower Mureș. It seems that 


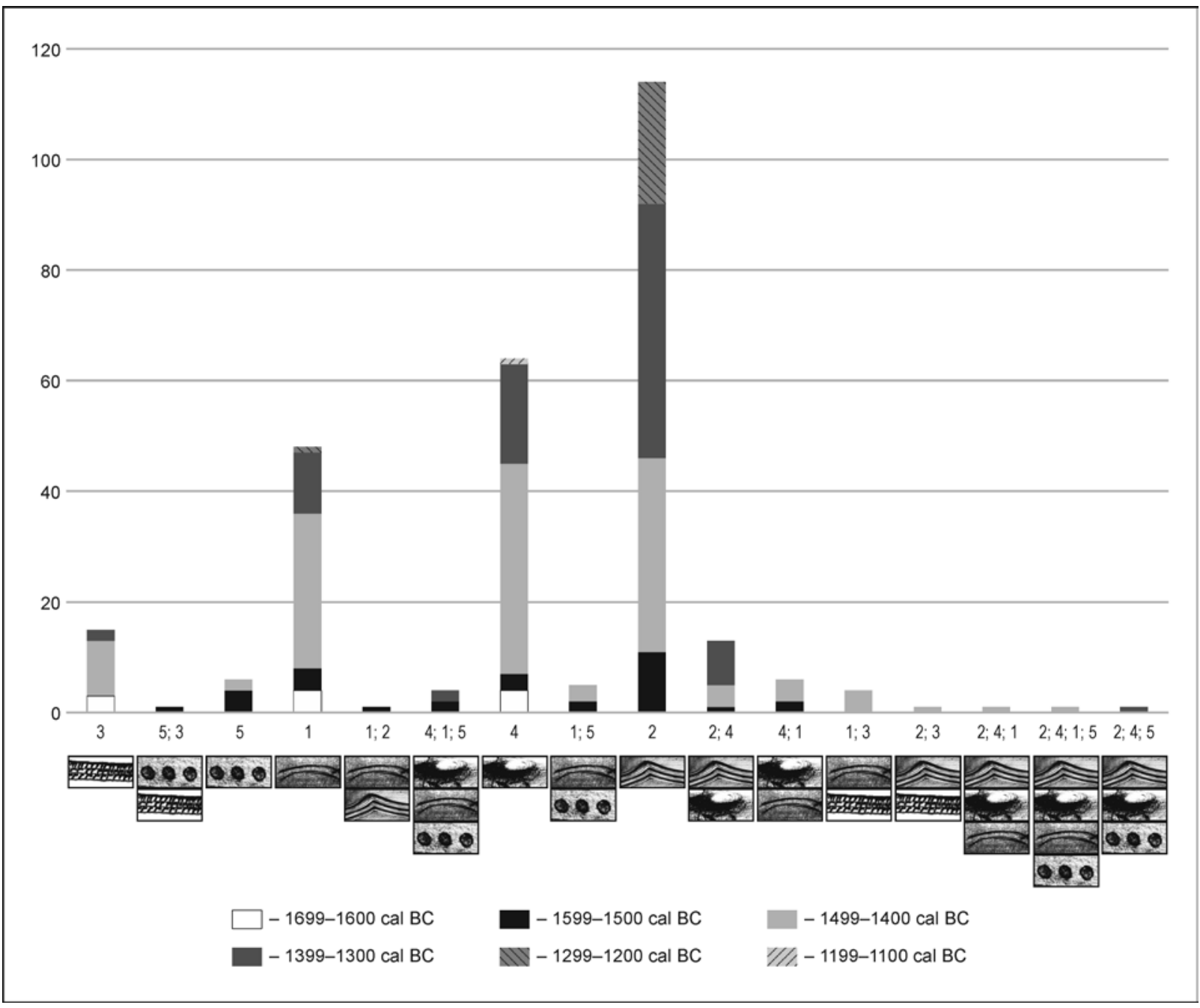

Fig. 23. Chronological distribution and frequency of the association of pottery decoration techniques. Graphic by the author.

certain sites such as Foeni, Giroc and Tápé continue MBA decoration traditions, while at other sites such as Pecica, Sântana and Șagu channelled decoration is being widely adopted as early as LBA I (Sava V., in press). In this context, recent opinions regarding the spread of channelled pottery from the northern Tisza region, north-western Romania and northeastern Hungary (see for example Dietrich 2015, 166; Metzner-Nebelsick 2012, 65, 66, 72) should be called into question, or at the very least nuanced. The available data indicate that channelled pottery is prevalent after $1600 \mathrm{BC}$ in some sites from the Lower Mureș Basin. This does not deny the importance of the northern Tisza region in the spread of the channelled pottery; however, in the absence of absolute dates coming from contexts with channelled pottery in that region, it is hard to make strong claims based on relative chronology alone.

All five decoration techniques appear in most of the contexts here under analysis. Although the excessive fragmentation of the pottery should be taken into account when interpreting these results, there is a tendency towards not combining different decoration techniques (Fig. 22; 23). Incised decoration is most frequently combined with impressions, embossed decoration or pseudo-cord decoration, while channelled decoration is mostly combined with embossed decoration. There are very few pottery sherds on which channelled decoration is found alongside incised decoration; usually, the two decoration techniques are mutually exclusive. The chronological distribution of the decoration techniques points towards some general tendencies, such as a marked increase in the combination between channelled decoration and embossed decoration between 1600 and $1300 \mathrm{BC}$.

There are no clear patterns at the present moment regarding the combination of pottery shapes and decoration techniques (Fig. 24; 25). Most of 

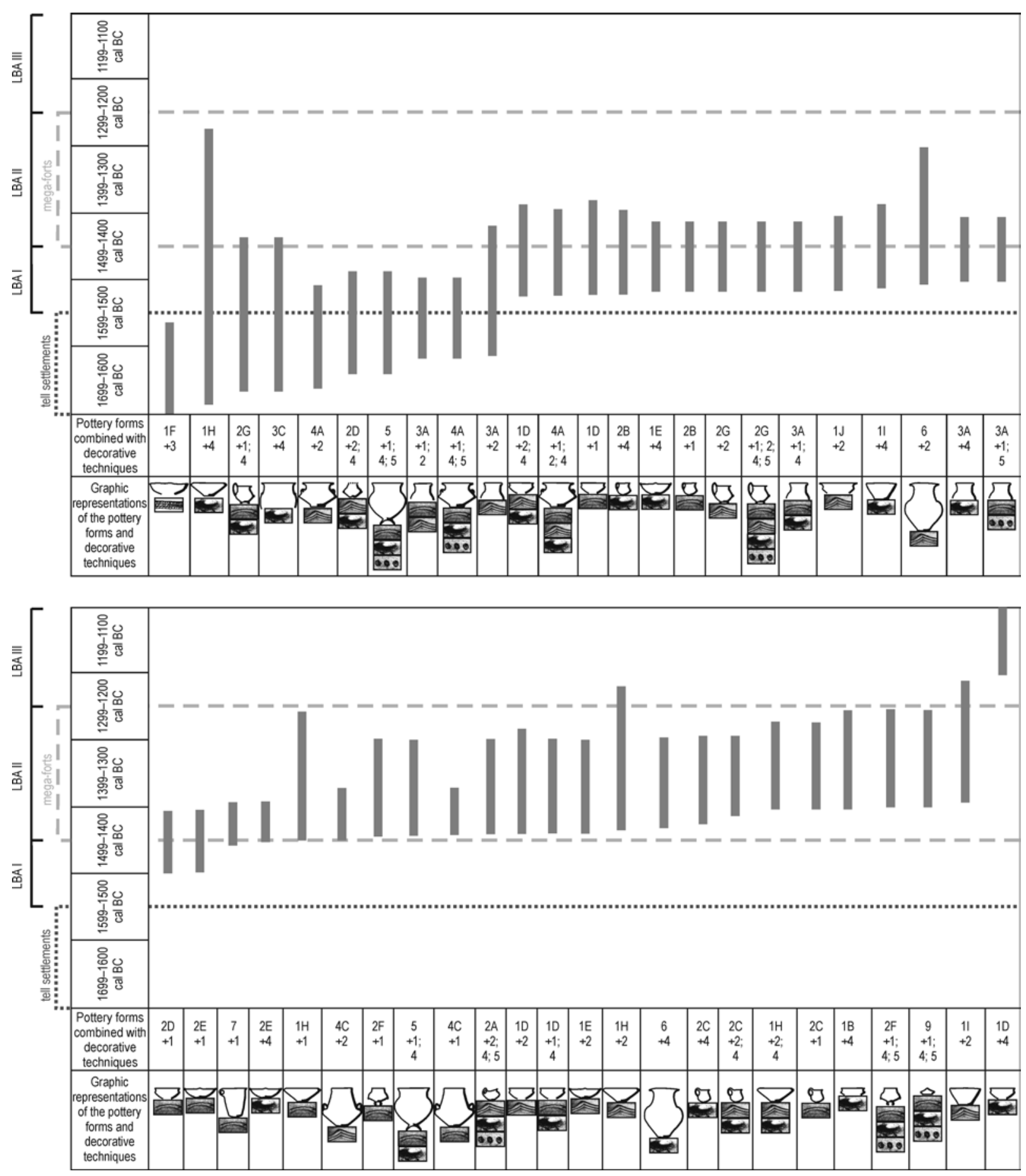

Fig. 24. Chronological distribution of the association of pottery decoration techniques according to pottery shapes. Graphic by the author.

the examples can only be found in single entries, a fact that cannot lend the certainty of a plausible explanation. Nevertheless, there is a clear preference for embossed decoration on dishes with inverted rims $(1 \mathrm{H}+4)$, or for channelled decoration on large biconical vessels $(6+2)$ and dishes with short neck and biconical body $(1 \mathrm{D}+2)$.

\section{Ornamental motifs}

For more than $52 \%$ of the pottery sherds registered in the database the ornamental motifs could be reconstructed. A total of 59 ornamental motifs could be identified, the majority of which were made by incision, followed by channelled 


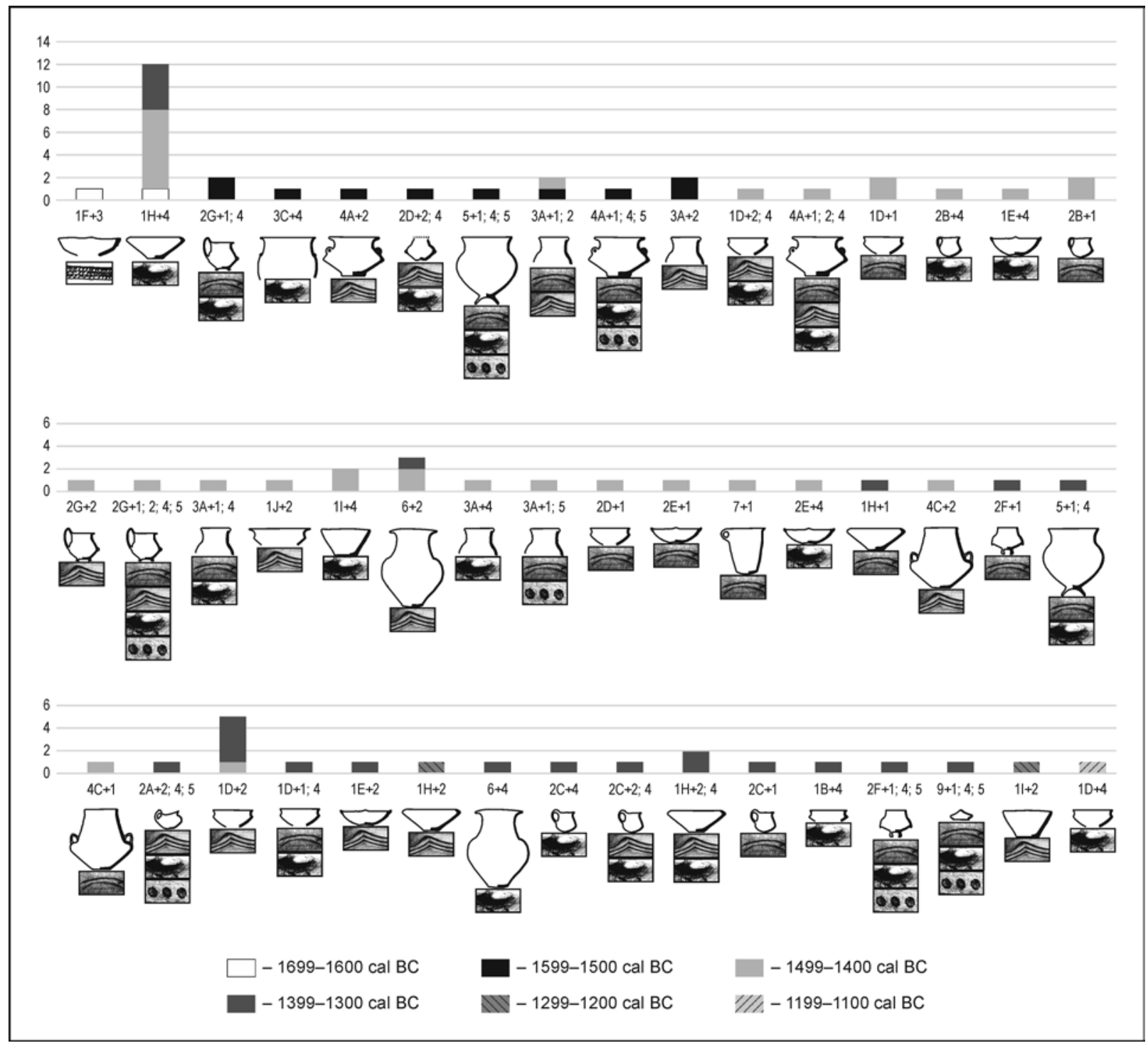

Fig. 25. Chronological distribution and frequency of the association of pottery decoration techniques according to pottery shapes. Graphic by the author.

decoration, embossed decoration, impression and pseudo-cord decoration (Fig. 26; Tab. 3).

It can be easily noticed (Fig. $27 ; 28$ ) that incised ornamental motifs are among the earliest, and that they continue to be in use for a long period of time, being employed in parallel with motifs made by channelled decoration. One of the most long-living ornamental motifs is the conical knob (4.1). Although numerous motifs are being used simultaneously for a long period of time, some of them seem to be associated with shorter chronological sequences, as is the case for the incisions displayed in a star shape on the base of the vessels (1.13), the wide double incisions displayed in a triangle (1.16), the wide double incisions displayed in an upturned triangle (1.17), the row of triangular incisions displayed on the inner rim (1.19) or the elongated and pointed knobs (4.3). The frequency of the motifs within different chronological sequences adds new information. For example, the rows of incised arches (1.12) and the rows of circular impressions (5.1) are mostly used between 1600 and $1500 \mathrm{BC}$; the rows of wide horizontal incisions (1.8), the wide horizontal channellings (2.11), the horizontal pseudo-corded lines (3.1), the vertical pseudo-corded lines (3.2) and the conical knobs (4.1), although being used for a longer period of time, are encountered predominantly between 1500 and $1400 \mathrm{BC}$; different types of channellings, such as the narrow horizontal ones (2.2), the narrow channellings displayed in a circle on the base of the vessel (2.3), the narrow channellings 


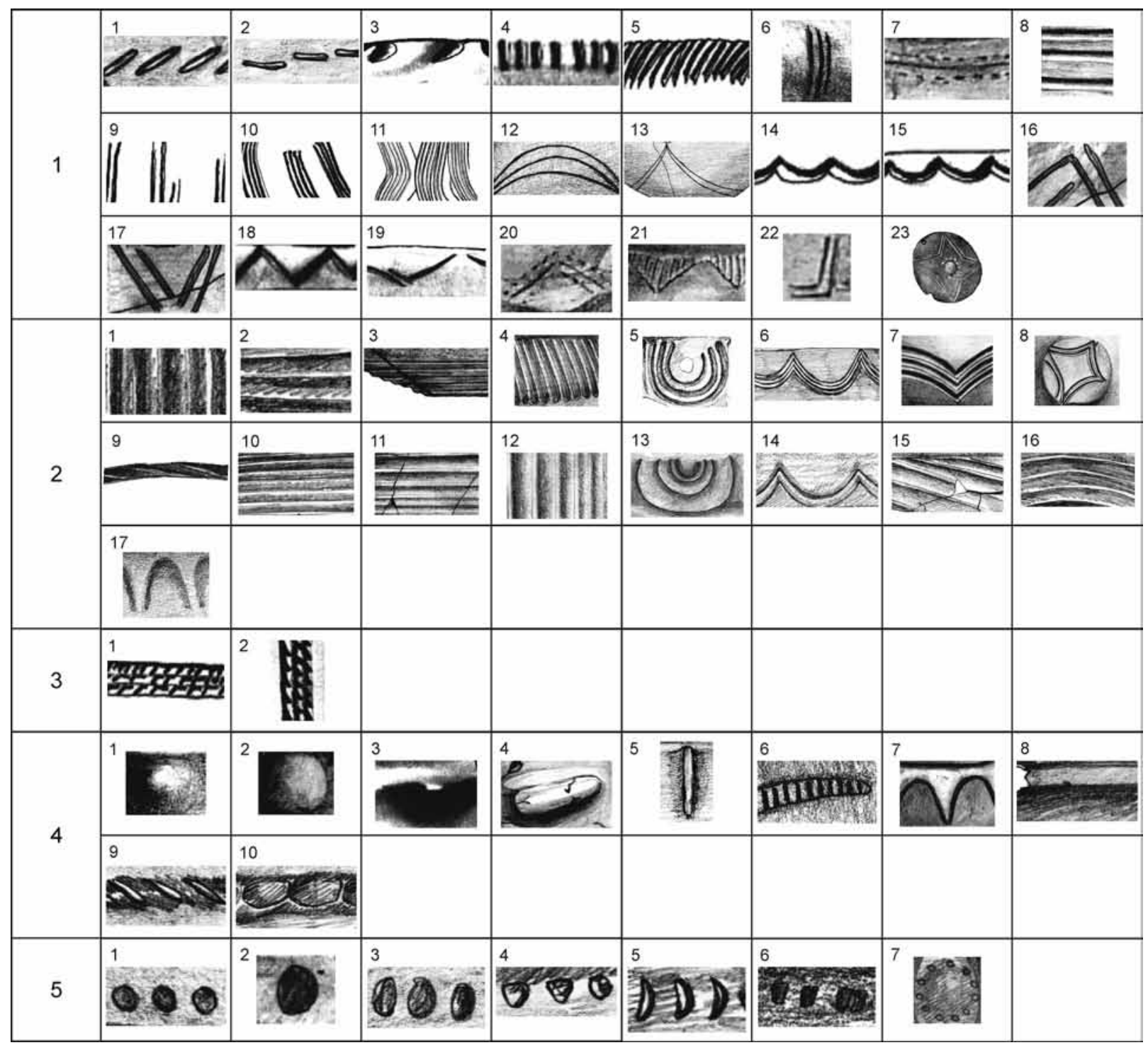

Fig. 26. Typological table of decorative motifs. Graphic by the author.

displayed semi-circularly (2.5), the wide vertical channellings (2.12), the wide channellings displayed semi-circularly (2.13) and the wide channellings displayed in a garland pattern (2.14) are characteristic for the period between 1400 and $1300 \mathrm{BC}$, while the narrow oblique channellings displayed on the rim (2.9), the narrow channellings displayed semi-circularly on the inner rim (2.10) and the wide channellings displayed in a circle on the rim (2.16) are encountered after 1300 BC.

The combination of different ornamental motifs offers more clues regarding certain preferences (Fig. 29; 30). The repertoire of these combinations is rather rich. An important point that should be outlined is the connection between the chronological evolution of the LBA and a decrease in the complexity of pottery decoration. Thus, while between 1600 and $1500 \mathrm{BC}$ the surface of the pottery vessels was decorated with numerous ornamental motifs, after $1400 \mathrm{BC}$ there is a gradual reduction in the number of ornamental motifs being employed, leading to a considerable decrease in the combination of ornamental motifs after $1300 \mathrm{BC}$. As a rule, the vessels with channelled decoration display fewer motifs than the ones with incised decoration.

In most cases, the combination of ornamental motifs with pottery shapes is not conclusive due to the limited number of entries in the database (Fig. 31;32). The only visible tendency is the frequent association of dishes with inverted rims with the conical knob ornament $(1 \mathrm{H}+4)$. 
Tab. 3. List of the decorative techniques and motifs (Fig. 26).

\begin{tabular}{|c|c|}
\hline Decoration techniques & Decorative motifs \\
\hline 1. Incisions & $\begin{array}{l}\text { 1.1. Row of short oblique incisions } \\
\text { 1.2. Row of short horizontal incisions } \\
\text { 1.3. Row of short oblique incisions (alveoli) displayed on the rim } \\
\text { 1.4. Row of short vertical incisions displayed on the inner rim } \\
\text { 1.5. Row of short oblique incisions displayed on the inner rim } \\
\text { 1.6. Row of slightly concave incisions } \\
\text { 1.7. Stripe made of a horizontal incision framed by small incisions } \\
\text { 1.8. Rows of wide horizontal incisions Rows of incised arches } \\
\text { 1.9. Rows of vertical incisions } \\
\text { 1.10. Rows of incisions displayed in a semi-circular pattern } \\
\text { 1.11. Rows of wavy incisions } \\
\text { 1.12. Rows of incised arches } \\
\text { 1.13. Incisions displayed in a star shape on the base of the vessel } \\
\text { 1.14. Wide incisions displayed in a garland pattern } \\
\text { 1.15. Wide incisions displayed in a garland pattern on the inner rim } \\
\text { 1.16. Double wide incisions displayed in a triangle shape } \\
\text { 1.17. Double wide incisions displayed in an upturned-triangle shape } \\
\text { 1.18. Row of narrow incisions displayed in a triangle shape } \\
\text { 1.21. Rows of triangular incisions displayed on the inner rim } \\
\text { 1.22. L-shaped incisions } \\
\text { 1.20isions displayed in a star shape }\end{array}$ \\
\hline 2. Channellings & $\begin{array}{l}\text { 2.1. Narrow vertical channellings } \\
\text { 2.2. Narrow horizontal channellings } \\
\text { 2.3. Narrow channellings displayed in a circle on the base of the vessels } \\
\text { 2.4. Narrow oblique channelling } \\
\text { 2.5. Narrow channellings displayed semi-circularly } \\
\text { 2.6. Narrow channellings displayed in a garland pattern } \\
\text { 2.7. Arches made of narrow channellings } \\
\text { 2.8. Narrow channellings displayed in a star shape on the base of the vessel } \\
\text { 2.9. Oblique narrow channellings } \\
\text { 2.10. Narrow channellings displayed semi-circularly on the inner rim } \\
\text { 2.11. Wide horizontal channellings } \\
\text { 2.12. Wide vertical channellings } \\
\text { 2.13. Wide channellings displayed semi-circularly } \\
\text { 2.14. Wide channellings displayed in a garland pattern } \\
\text { 2.15. Wide oblique channellings } \\
\text { 2.16. Wide channellings displayed in a circle on the inner rim } \\
\text { 2.17. Wide channellings displayed in arches }\end{array}$ \\
\hline 3. Pseudo-twisted cord & $\begin{array}{l}\text { 3.1. Horizontal pseudo-twisted cord lines } \\
\text { 3.2. Vertical pseudo-twisted cord lines }\end{array}$ \\
\hline
\end{tabular}


Tab. 3. Continuation.

\begin{tabular}{|c|c|}
\hline Decoration techniques & Decorative motifs \\
\hline 4. Embossed decorations & $\begin{array}{l}\text { 4.1. Conical knob } \\
\text { 4.2. Circular knob } \\
\text { 4.3. Elongated and pointed knob } \\
\text { 4.4. Elongated rectangular knob } \\
\text { 4.5. Vertical narrow rib } \\
\text { 4.6. Indented rib } \\
\text { 4.7. Embossed arches } \\
\text { 4.8. Horizontal rib } \\
\text { 4.9. Stripe made of indentations } \\
\text { 4.10. Stripe made of alveoli }\end{array}$ \\
\hline 5. Impressions & $\begin{array}{l}\text { 5.1. Row of circular impressions } \\
\text { 5.2. Circular impression } \\
\text { 5.3. Row of oval impressions } \\
\text { 5.4. Row of small impressions shaped like an upturned triangle } \\
\text { 5.5. Row of crescent-shaped impressions } \\
\text { 5.6. Row of rectangular impressions } \\
\text { 5.7. Impressions displayed in a circle }\end{array}$ \\
\hline
\end{tabular}

\section{DISCUSSION}

In addition to identifying stylistic features characteristic for different chronological sequences expressed in absolute dates, in some cases it was also possible to follow the evolution of certain pottery shapes and certain combinations of ornamental motifs for a period spanning two centuries. A first example is the biconical vessel richly ornamented with various incised motifs, embossed decoration and channelled decoration uncovered in the settlement from Şagu-Site A1_1, cx. 291 a feature dated to the $16^{\text {th }} \mathrm{c}$. BC. This vessel shape and the manner in which the ornaments are displayed are the prototypes for the specimen found in grave cx. 98 from the cemetery at Pecica-Site 14 (Fig. 33) dated to the $15^{\text {th }} \mathrm{c}$. BC. Another example is that of the vessels uncovered in grave cx. 67 from Pecica-Site 14 and in feature cx. 93 from Șagu-Site A1_1 (Fig. 34). Although the same ornamental motifs are being preserved, in both cases the incised decoration is gradually replaced by channelled decoration.

Another important aspect in the context of discussing the emergence and development of LBA pottery is the visible continuation of a strong MBA tradition in pottery shapes, decoration techniques and ornamental motifs (Duffy et al. 2019, fig. 6; Saval Gogâltan 2019, 227; Sava/Ignat 2016, 195). In a broader context, it can be stated that some MBA pottery styles such as Otomani-Füzesabony or Wietenberg continue to be used until 1400-1300 BC, being contemporary with some LBA pottery styles. At the same time, some of the LBA pottery styles such as Cruceni-Belegiš, Pișcolt-Cehăluț/Hajdúbagos, Noua, and Lăpuș continue many MBA pottery traditions, especially the use of incised decoration. After 1500 BC, channelled decoration becomes the predominant type of pottery decoration in western Romania and eastern Hungary, while large biconical vessels, dishes with inverted rims and cups with high handle rising above the rim become the standard pottery shapes for a vast area. The channelled decoration and the aforementioned pottery shapes are in fact elements of an MBA tradition that will be in use until late in the EIA.

There were two main pottery styles evolving during the MBA in the Lower Mureș: Mureș and Cornești-Crvenka. The analysis of the excavations undertaken at Pecica-Şanţul Mare, the tell settlement where the most representative pottery assemblage of the Mureș style was uncovered (Soroceanu 1991, fig. 4; 10-15) indicated that certain MBA shapes, techniques and ornamental motifs were preserved in the LBA, reference being made here to cups of the $2 \mathrm{D}$ type, dishes belonging to types $1 \mathrm{~A}$ and $1 \mathrm{G}$, trays (8) and vessels of type 7; as for the decoration techniques, there is a clear tendency, especially in the upper layers from Pecica, towards an increased 

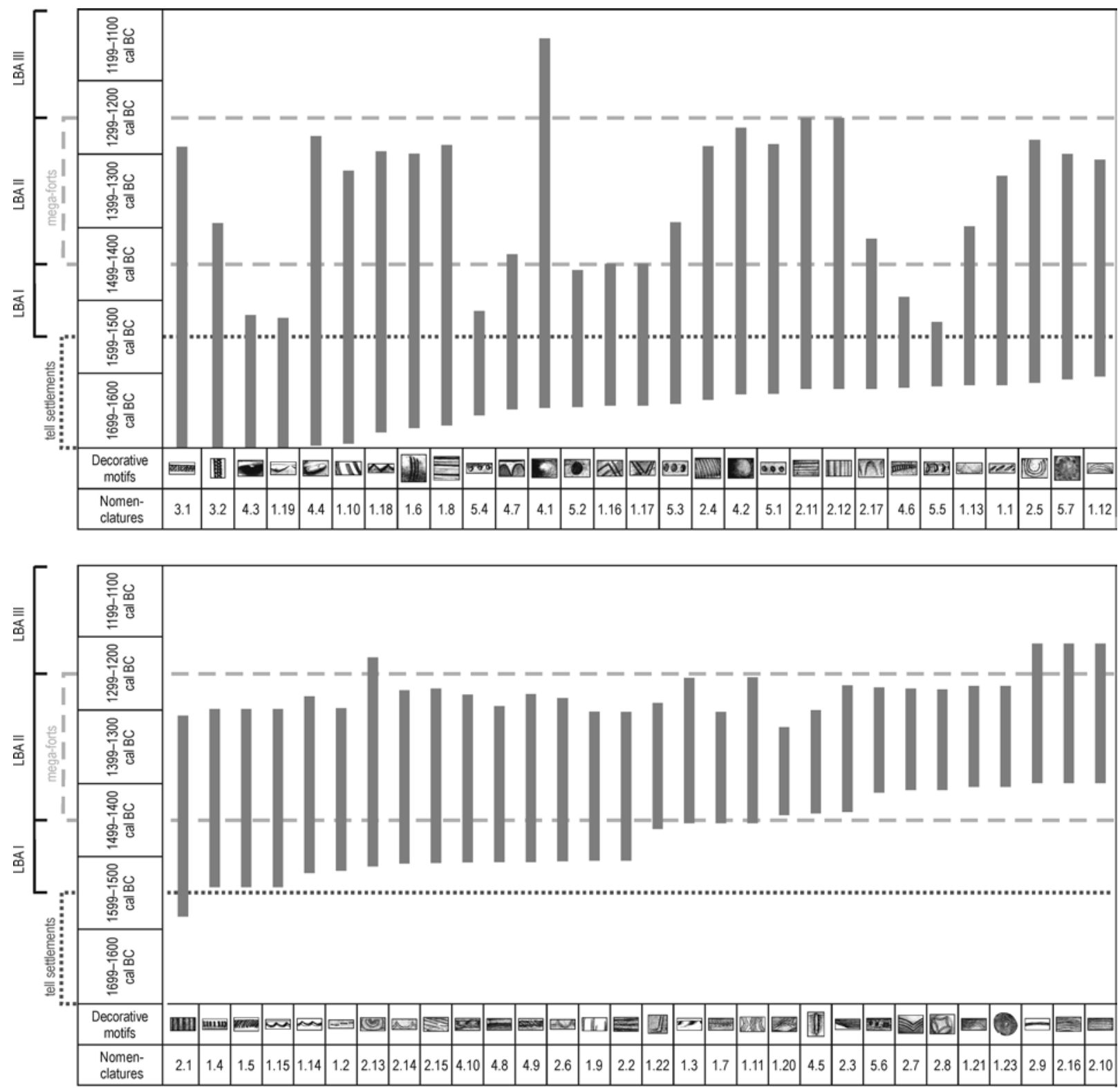

Fig. 27. Chronological distribution of decorative motifs. Graphic by the author.

use of channelled decoration; ornamental motifs that stem clearly from a MBA Mureș tradition are the narrow channellings displayed in a semi-circle (2.5), the circular knobs (4.2) and the impressions displayed in a circle (5.7). A similar phenomenon is encountered in other parts of western Romania, for example north of the Mureș River during the last phase of the Otomani-Füzesabony pottery style (Molnár 2014, 70-78, 85-92), or in the Sătmar plain in the contemporary Suciu de Sus I group (Pop 2009, 13-18). A more significant number of elements from the Cornești-Crvenka pottery style (Gogâltan 2004; Gumă 1997, 43-47) are being continued during the LBA, such as cups belonging to type $2 \mathrm{G}$, pots of the $3 \mathrm{~A}$ type, dishes belonging to the $1 \mathrm{E}$ type or incised ornaments such as the rows of slightly concave incisions (1/6), rows of incised arches (1.12), wide incisions displayed in a garland pattern (1.14), wide incisions displayed in a garland pattern on the inner rim (1.15), rows of narrow incisions displayed in the shape of a triangle (1.18) and rows of triangular incisions displayed on the inner rim (1.19). Besides some specific MBA traditions that are continued during the LBA, such as large inhumation cemeteries, the placement of the dead according to strict rules and deposition practices, there are also several shapes, decoration techniques and ornamental motifs that are in use during both the MBA and the LBA. All these facts indicate that the LBA in the Lower Mures Basin is defined by several MBA traditions. 


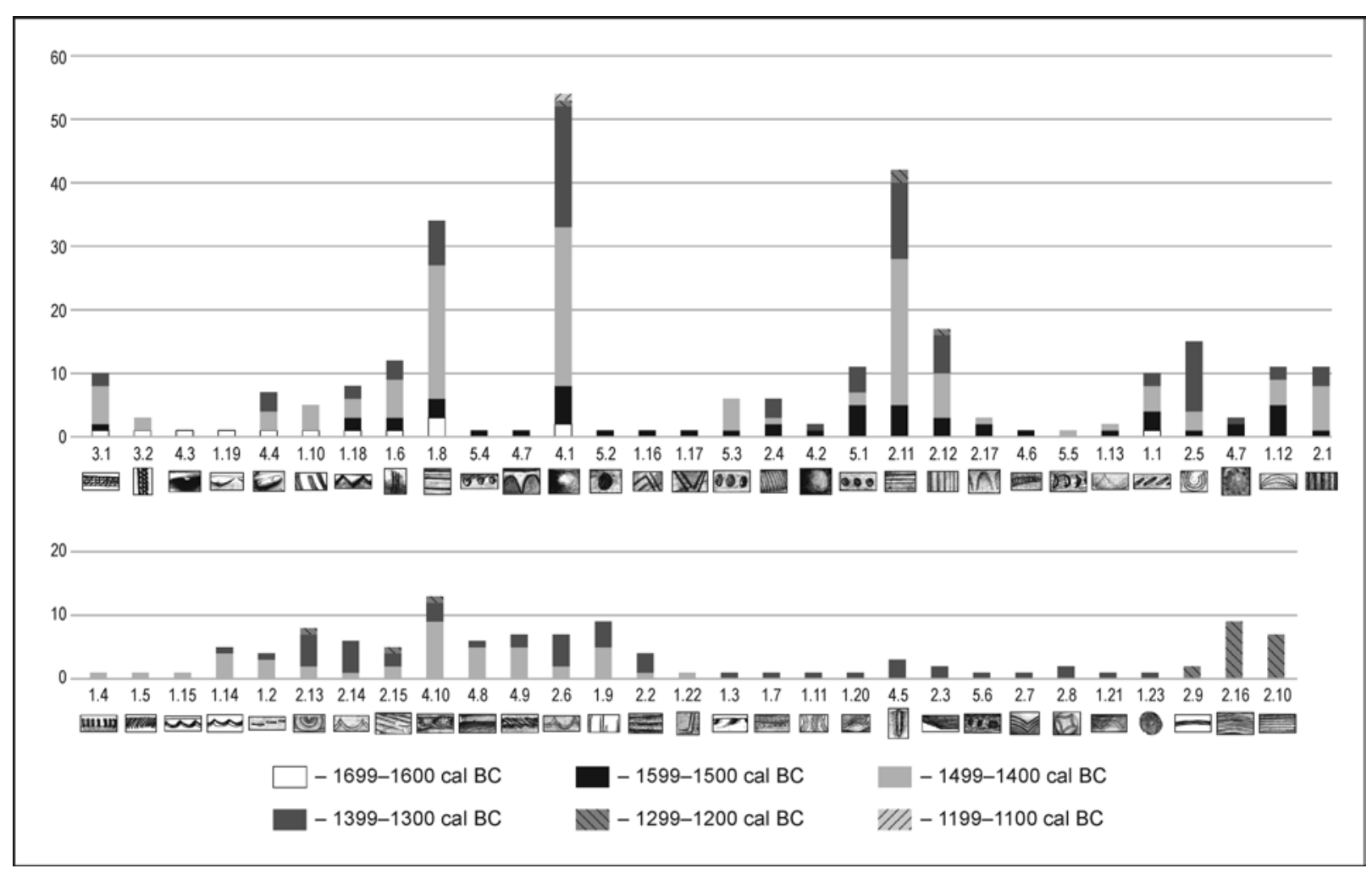

Fig. 28. Chronological distribution and frequency of decorative motifs. Graphic by the author.

At the same time, a continuation of some of the shapes, decoration techniques and ornamental motifs developed throughout LBA I and LBA II into LBA III (a chronological sequence equated with the use of Gáva pottery) can be observed. This is also reflected by the inclusion within the Gáva pottery repertoire of certain shapes such as dishes with inverted rims $(1 \mathrm{H})$, dishes in the shape of a truncated cone (1I) and large biconical vessels (6), along with numerous channelled decoration motifs such as narrow vertical channellings (2.1), narrow horizontal channellings (2.2), narrow channellings displayed in a garland pattern (2.6), wide channellings displayed in a garland pattern (2.14), wide oblique channellings (2.15), etc. (Kósa 2018, 14-29; László 1994, 65-87, 111-124; Levițki 1994, 79-107; Pankau 2004, 51-83; Szabó 2017). It should be mentioned that during LBA III channelled decoration becomes the predominant decoration technique. Beginning with this phase and until the end of the LBA this fashion spreads throughout most of Romania, the Moldavian Republic, Slovakia, Hungary and Serbia. Even during the first phase of the EIA, until the $7^{\text {th }} \mathrm{c}$. BC, channelled decoration continues to be the preferred pottery decoration technique (Ursuțiu 2002, 49). Parallel to the development of channelled decoration, we can also see a preference for certain shapes such as biconical vessels (6), biconical dishes with inverted rims and cups with handles rising above the rim. Although channelled pottery from the inner Carpathian region is commonly, and erroneously, exclusively associated with the Gáva style, it should be noted that during the Gáva period we are only witnessing the peak of channelled decoration usage, this technique originating much earlier and continuing its evolution even after the disappearance of the Gáva pottery.

The pottery analysis undertaken in the paragraphs above has shown that delineating relative chronological sequences based on the typological evolution of pottery cannot be used as a substitute for radiocarbon dates. Furthermore, as more absolute dates become available, it becomes increasingly clear that existing typo-chronologies need to be substantially revised. The aim of this paper, besides establishing the absolute chronology of pottery coming from the contexts presented above, was to devise a relative chronological scheme that can be easily applied to the Lower Mures region. By combining the contextual analysis with the absolute chronology and the typology of shapes and pottery decoration, it became clear that establishing relative chronological markers based on the evolution of specific artefacts is almost impossible. Instead, stressing out historic events of a general character 

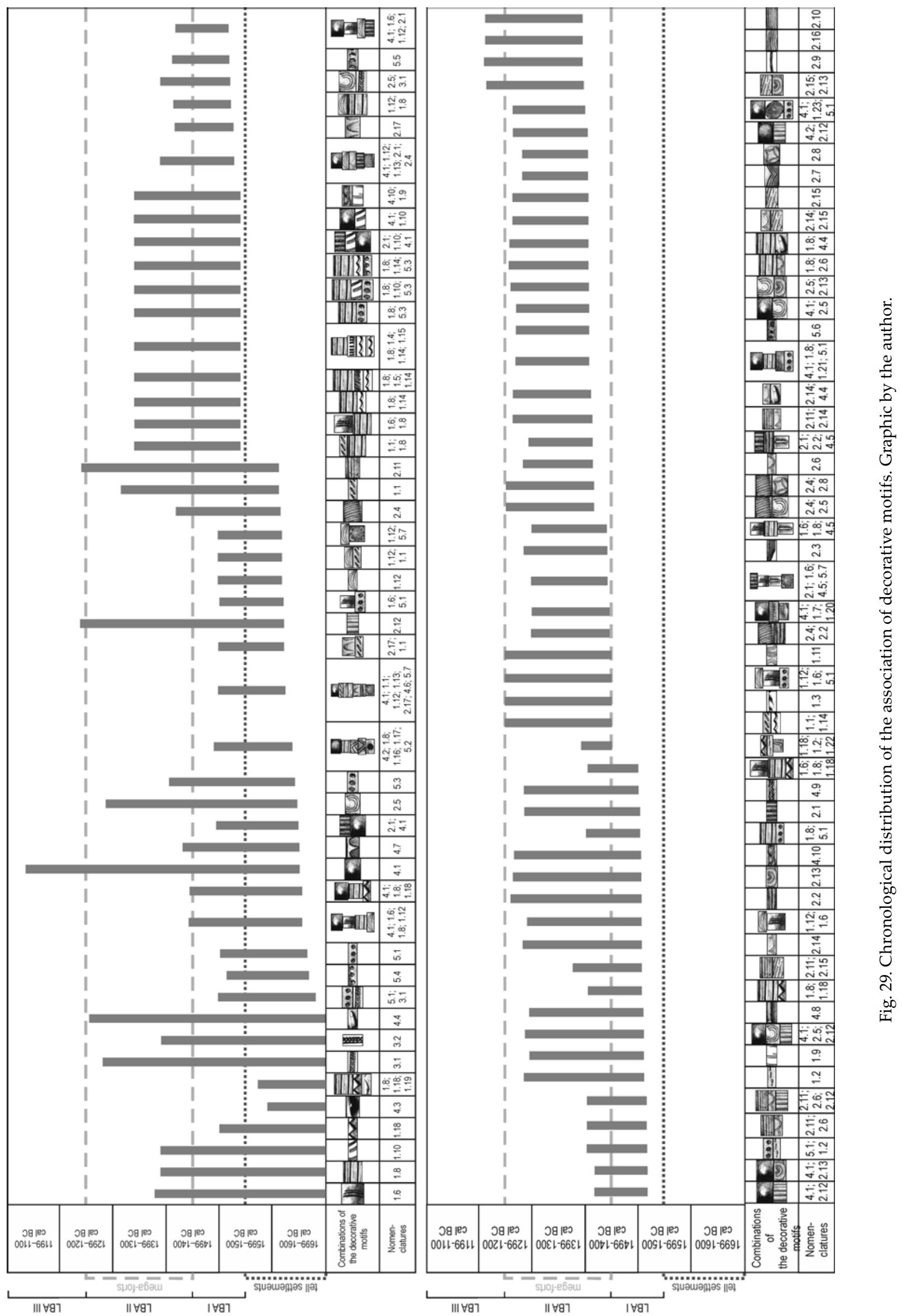


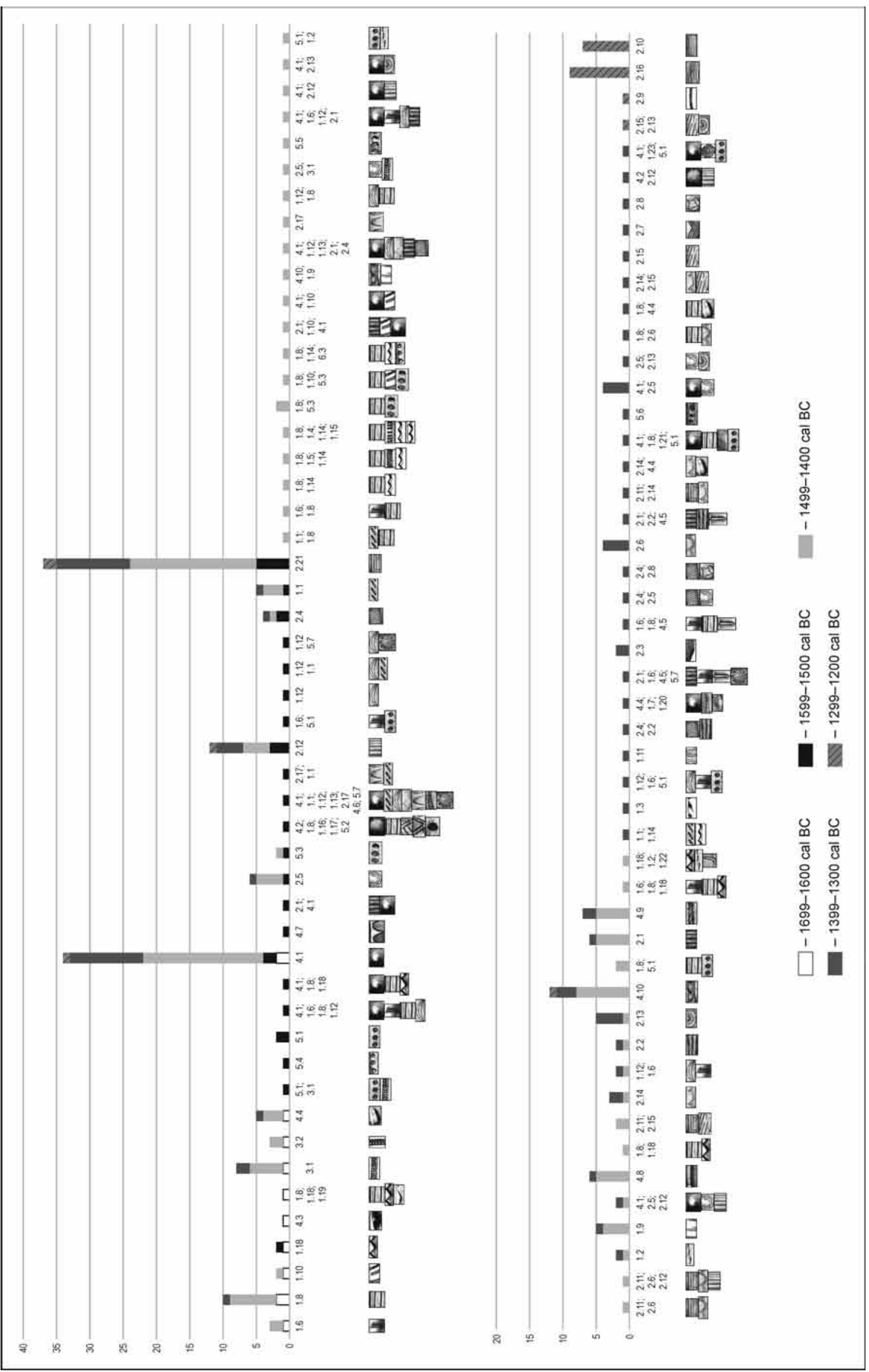

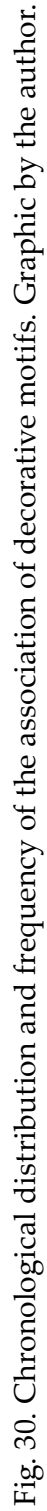




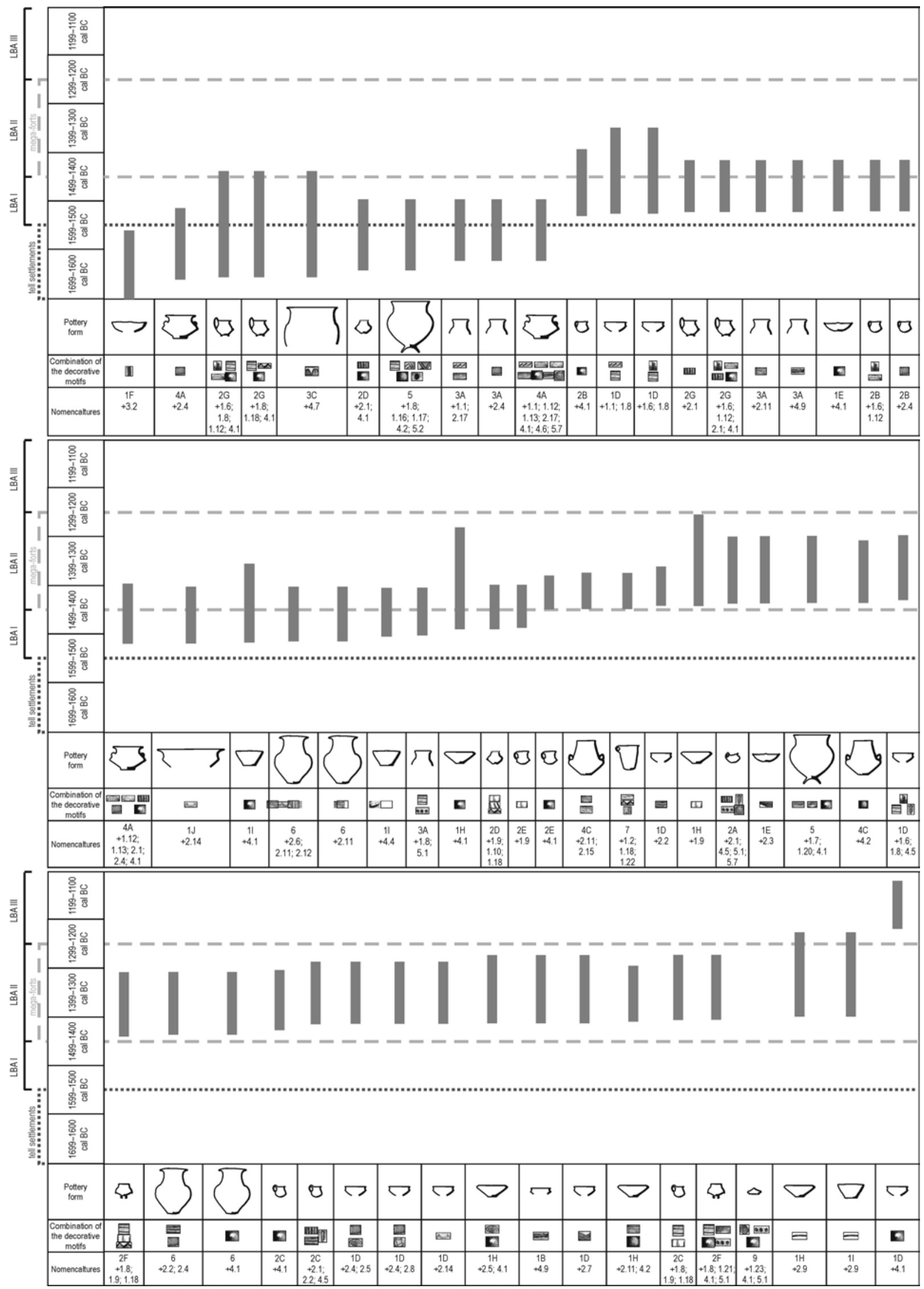

Fig. 31. Chronological distribution of decorative motifs according to pottery shapes. Graphic by the author. 


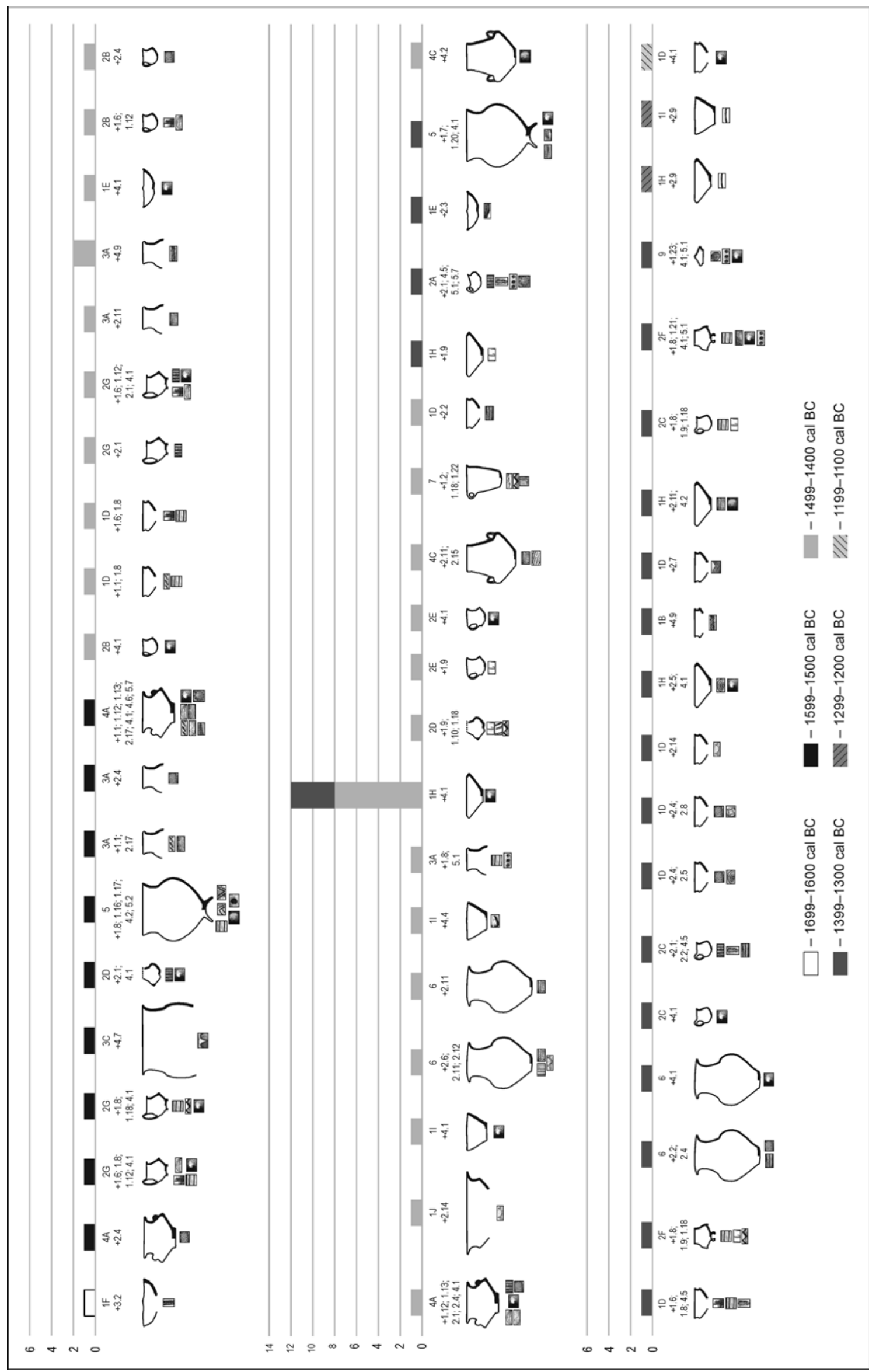

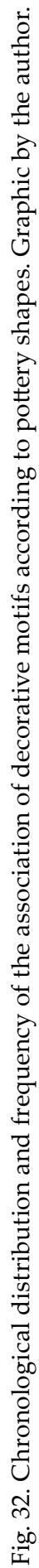




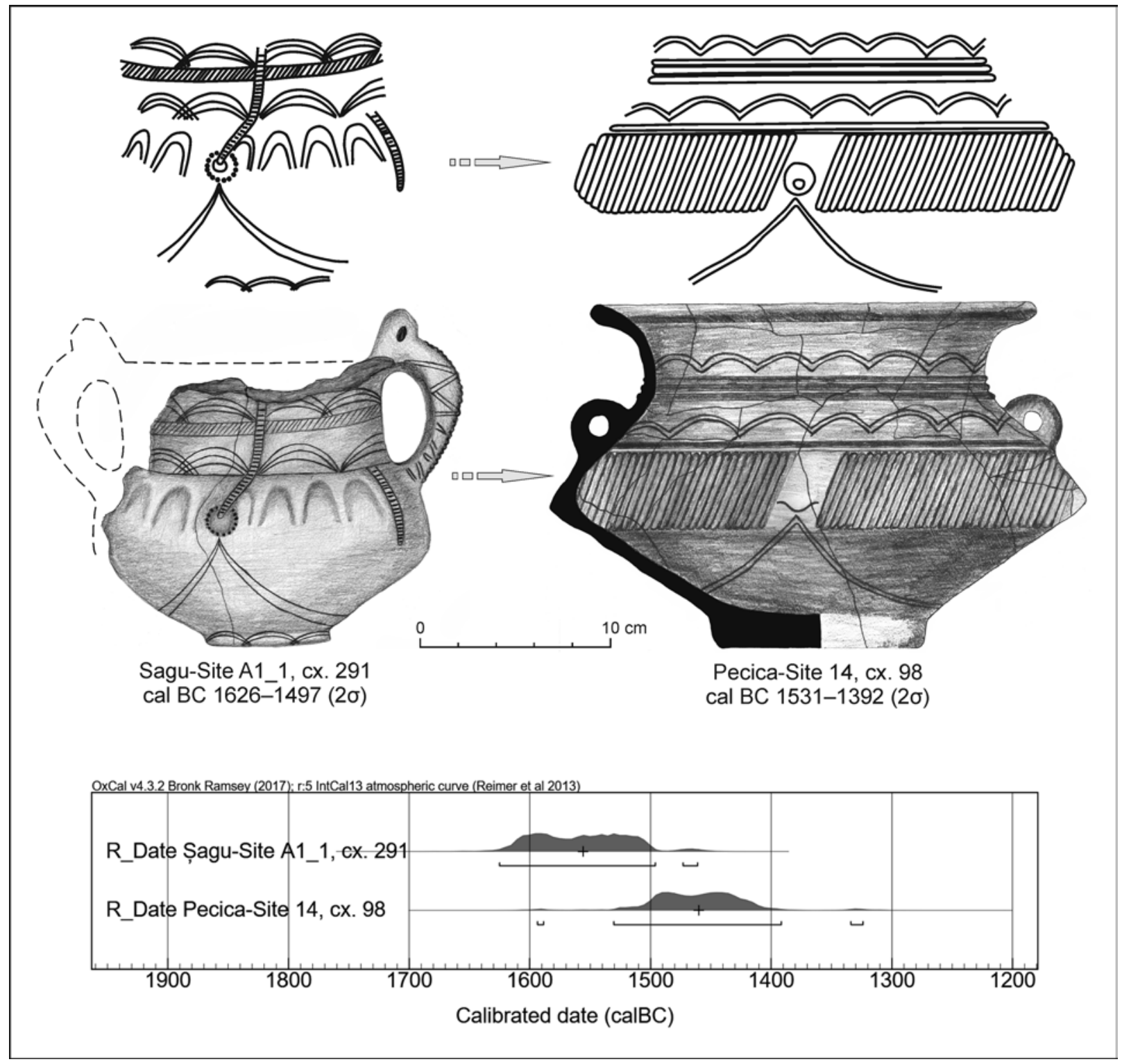

Fig. 33. An example of the evolution of pottery shapes, decoration techniques, and decorative motifs over one century. Graphic by the author.

seems to be a better criterion for devising a relative chronological system that should be complemented and validated by using radiocarbon dates. The main events taking place in the Lower Mureș Basin during the LBA have already been discussed in previous publications (Gogâltan/Sava 2019; Sava/Gogâltan 2019; Sava/Ignat 2016). As a result, the LBA in this region was divided in three main chronological phases (see above). LBA I coincides with the time interval framed on the one hand by the abandonment of tell settlements, and on the other hand by the construction of mega-forts, and can therefore be dated between 1550 BC-1450 BC (this chronological interval being established based on the relationship between the abandonment of the tell settlement from Pecica-Șanțul Mare - approximately 1550 BC and the construction of the third enclosure from Sântana-Cetatea Veche - approximately 1450 BC); LBA II covers the lifespan of the third enclosure from Sântana-Cetatea Veche and the use period of Rings I and II from Cornești-Iarcuri, a period that can be dated between approximately $1450 \mathrm{BC}$ and 1250 BC. LBA III coincides with the destruction of enclosure III from Sântana and Rings I and II from Cornești, as well as the abandonment of the settlements from Șagu-Site A1_1, Foeni-Gomila Lupului etc.; while the beginning of LBA III can be clearly outlined, the absence of archaeological excavations targeted at the investigation of this phase hinders a more detailed discussion regarding the duration 


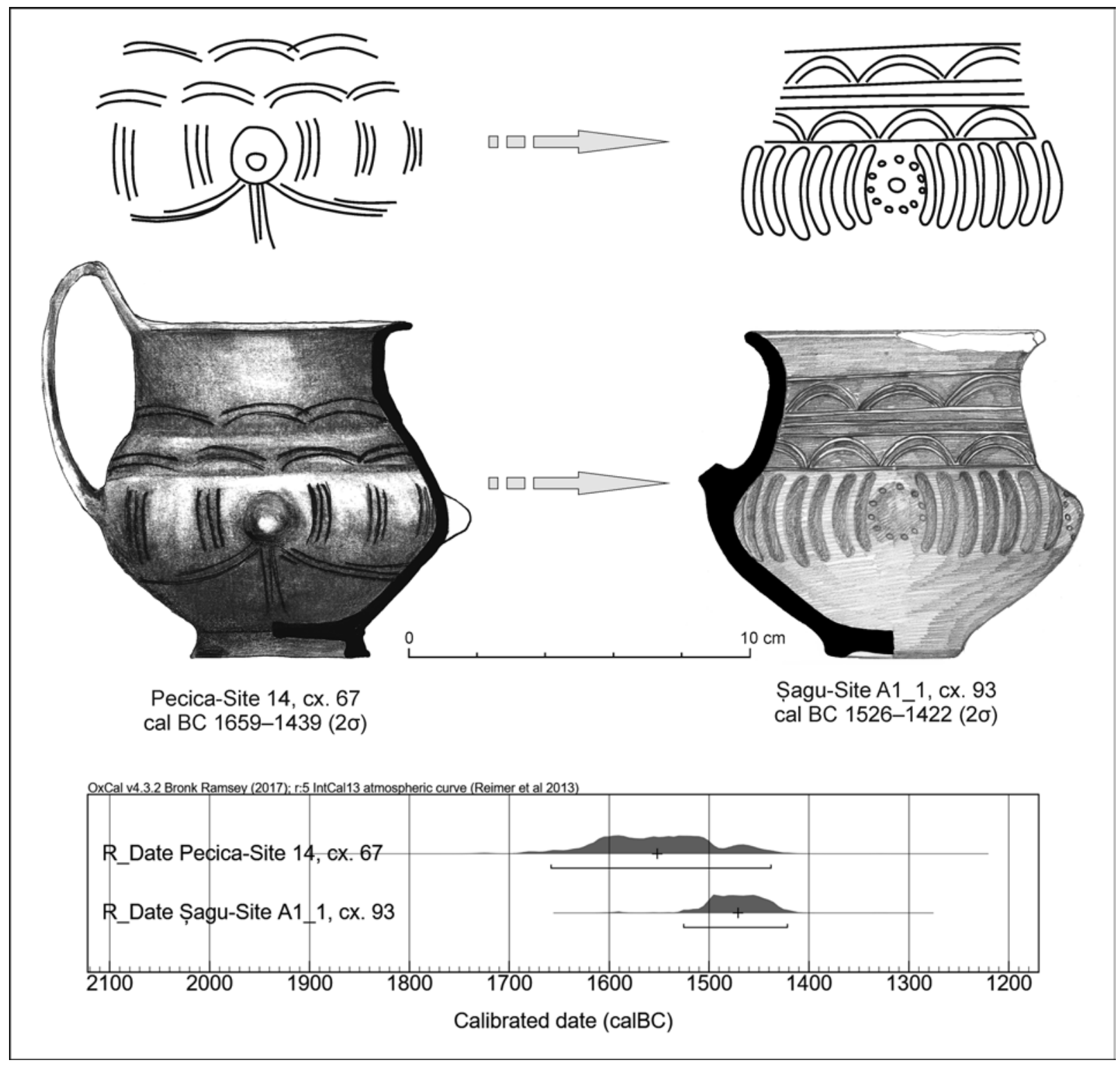

Fig. 34. An example of the evolution of pottery shapes, decoration techniques, and decorative motifs over one century. Drawings by A. Bezvovan, R. Tănăsache and the author.

and end of this chronological stage. It should be mentioned that the chronological phases suggested in this paper have also been adopted in other publications dealing with the LBA from the inner Carpathian region (Gogâltan 2019).

\section{CONCLUSIONS}

As could be seen, most of the dates incorporated within this analysis fall within an interval between approximately 1600 and 1300 BC. These absolute chronological markers frame the end of the MBA along with the LBA I and LBA II phases. By far the most frequent pottery shapes are the dishes, followed by cups and biconical vessels, shapes that will become ubiquitous after 1500 BC. Within the repertoire of decoration techniques, incised decoration (a MBA tradition) is replaced by channelled decoration, while within the field of ornamental motifs there is a tendency towards standardization during the LBA. However, it should be noted that several pottery traditions, each with its own trajectory and characteristics, coexisted in the Lower Mureș during the LBA. While some communities (Foeni, Giroc) continue to frequently employ incised and pseudo-cord decoration until approximately 1300 BC, other communities (Pecica, Șagu) adopt channelled decoration from early on (1600-1500 BC). 
The pottery analysis undertaken here offers a new perspective on the chronological evolution of the Lower Mureș and surrounding regions during the LBA. First, the radiocarbon dates from Giroc-Mescal, Foeni-Gomila Lupului, Șagu-Site A1_1 and Pecica-Site 14 confirm earlier assumptions (Sava/Gogâltan 2019, 223; Sava/Ignat 2016, 191, 192) that the last MBA layer from Pecica-Șanțul Mare is contemporary with several settlements and cemeteries that can be assigned to the LBA I based on the assemblages found within. Beginning with the construction of the mega-forts (ex. Sântana-Cetatea Veche), the standardisation of pottery shapes and decoration and the widespread adoption of channelled decoration become more and more visible in the material record. These characteristics become even more salient after the destruction of the megaforts and the distribution of Gáva-type pottery.

The results of this analysis that combined pottery with radiocarbon dates and contexts show that pottery cannot be used as a stable chronological marker in order to construct relative chronological schemes. At the same time, the importance of incorporating radiocarbon dates in the typological and stylistic analysis of pottery is clearly highlighted. Furthermore, the analysis revealed that the evolution of a certain shape, decoration technique or ornamental motif can follow different trajectories even within the same micro-region, which challenges the paradigm of archaeological cultures/styles uniformly distributed over large areas.
On another level, the profound changes of the pottery styles are closely connected with the main events of the LBA. Events like the abandonment of the tells, the construction of mega-forts, and the associated socio-economic growth, can only be properly understood within the broader framework of developments taking place in Europe during the period between the $16^{\text {th }}-15^{\text {th }}$ and $13^{\text {th }}-12^{\text {th }}$ centuries $\mathrm{BC}$. Here reference is being made to the emergence of the Terramare culture (Cardarelli 2009; Vanzetti 2013) whose evolution closely resembles that of the LBA in the Lower Mureș. At the same time, similar trajectories can be documented all over Europe, reflected by a steady increase in the number of weapons in the archaeological record, the construction of numerous fortifications, the ubiquity of violent conflicts, an increase in mobility, the pervasiveness of bronze artefacts or the development of trade routes (see, for example Hansen 2019b; Harding 2007; Jung 2016; Jung/Mehofer 2013; Krause 2019b; Kristiansen/Larsson 2005; Molloy/Horn 2020; O'Brien 2018; Terberger et al. 2018). This entire system suffers a collapse during the $13^{\text {th }}-12^{\text {th }}$ centuries BC.

The main challenge for future studies dealing with the LBA in the inner Carpathian area and surrounding regions will be the collection and publication of a larger number of radiocarbon dates from features with rich ceramic assemblages in order to establish a reliable absolute chronology. These dates should then form the basis of a chronology of the main events that shaped the history of each region.

\section{LITERATURE}

Andrițoiu 1992 - I. Andrițoiu: Civilizația tracilor din sud-vestul Transilvaniei în Epoca Bronzului. Bibliotheca Thracologica 2. București 1992.

Bader 2012 - T. Bader: Bemerkungen über die Gáva Kultur. Geschichte und Stand der Forschung. Ein Überblick. Satu Mare - Studii și Comunicări 28/1, 2012, 7-22.

Bălan 2013 - G. Bălan: Așezările fortificate din aria culturii Gáva din România. In: S. C. Ailincăi/A. Țârlea/C. Micu (eds.): Lower Danube Prehistory. 50 years of excavation at Babadag (1962-2012). Proceedings of "Lower Danube Prehistory. 50 years of excavations at Babadag." $20^{\text {th }}-22^{\text {th }}$ September 2013, Tulcea. Brăila 2013, 265-310.

Bălan/Quinn/Hodgins 2016 - G. Bălan/C. P. Quinn/G. Hodgins: The Wietenberg culture. Periodization and chronology. Dacia 60, 2016, 67-92.

Blischke 2002 - J. Blischke: Gräberfelder als Spiegel der historischen Entwicklung während der mittleren Bronzezeit im mittleren Donaugebiet. Universitätsforschungen zur prähistorischen Archäologie 80. Bonn 2002.

Boroffka 1994 - N. G. O. Boroffka: Die Wietenberg-Kultur. Ein Beitrag zur Erforschung der Bronzezeit in Südosteuropa. Universitätsforschungen zur prähistorischen Archäologie 19. Bonn 1994.

Boroffka/Luca 1995 - N. Boroffka/S. A. Luca: Archäologische Metallfunde aus der Schulsammlung Beliu, Kr. Arad. In: T. Soroceanu (red.): Bronzefunde aus Rumänien. Prähistorische Archäologie in Südosteuropa 10. Berlin 1995, 225-228.

Bukvić 2000 - L. Bukvić: Kanelovana keramika Gava komplexa u Banatu. Novi Sad 2000.

Capuzzo et al. 2018 - G. Capuzzo/M. Zanon/M. Dal Corso/ W. Kirleis/J. A. Barceló: Highly diverse Bronze Age population dynamics in Central Southern Europe and their response to regional climatic patterns.

\footnotetext{
Acknowledgements

I am grateful to Dr. Habil. Florin Gogâltan, Dr. Dragoș Diaconescu, Dr. Alexandra Găvan, Dr. Alin Frînculeasa, Dr. Florin Mărginean and Dr. Norbert Kapcsos for their valuable advice, their help in correcting the manuscript and their comments regarding the obtained results along with the manner in which these results should be presented, all of which have led to a substantial improvement of the interpretations.
} 
PLoS One 13, 2018, e0200709.

DOI: https://doi.org/10.1371/journal.pone.0200709

Cardarelli 2009 - A. Cardarelli: The collapse of the Terra mare culture and growth of new economic and social systems during the Late Bronze Age in Italy. Scienze dell'antichità. Storia Archeologia Antropologia 15, 2009, 449-520.

Cavazzuti et al. 2019 - C. Cavazzuti/R. Skeates/A. R. Millard/G. Nowell/J. Peterkin/M. B. Brea/A. Cardarelli/ L. Salzani: Flows of people in villages and large centres in Bronze Age Italy through strontium and oxygen isotopes. PLoS One 14, 2019, e0209693.

DOI: https://doi.org/10.1371/journal.pone.0209693

Chidioşan/Emődi 1982 - N. Chidioşan/J. Emődi: Grupul cultural Igrița de la sfârşitul epocii bronzului. Crisia 21, 1982, 61-86.

Chidioşan/Emődi 1983 - N. Chidioşan/J. Emődi: Descoperirile arheologice din peştera Izbândiş (com. Şuncuiuş) aparținând grupului cultural Igrița. Crisia 13, 1983, $17-32$.

Ciugudean 2010 - H. Ciugudean: The Late Bronze Age in Transylvania (With primary focus on the central and Southern areas). Satu Mare - Studii și Comomunicări 26/1, 2010, 157-202.

Ciugudean 2012 - H. Ciugudean: The chronology of the Gáva culture in Transylvania. In: W. Blajer (red.): Peregrinationes archaeologicae in Asia et Europa Joanni Chochorowski dedicatae. Kraków 2012, 229-243.

Ciugudean/Quinn 2015 - H. Ciugudean/C.P. Quinn: The End of the Wietenberg Culture in the Light of new ${ }^{14} \mathrm{C}$ Dates and its Chronological Relation Towards the Noua Culture. In: R. E. Németh/B. Rezi (eds.): Bronze Age Chronology in the Carpathian Basin. Proceedings of the International Colloquium from Târgu Mureş. 2-4 October 2014. Cluj-Napoca 2015, 147-178.

Ciugudean et al. 2019 - H. Ciugudean/C. Uhner/C. Quinn/ G. Bălan/O. Oargă/A. Balog/G. Balteș: După 25 de ani. Grupul Cugir-Band în lumina noilor cercetări. Apulum 56, 2019, 89-130.

Diaconescu et al. 2018a - D. Diaconescu/V. Bunoiu/A. Muscalu-Crețescu/I. Leonti/A. Hegyi/R. Pinca/S. Tincu: Susani, com. Traian Vuia, jud. Timiș, Punct: Grămurada de la Jupani. Cronica cercetărilor arheologice din România. Campania 2017. In: A 52-a sesiune naţională de rapoarte arheologice. Muzeul Național de Istorie al Transilvaniei. 15.-17. novembrie 2018, Cluj. București 2018, 131, 132.

Diaconescu et al. 2018b - D. Diaconescu/V. Bunoiu/A. Hegyi/ R. Pinca/A. Rusu/R. Quatert/I. Leonti/S. Bertea: Raport de cercetare arheologică privind obiectivul de la Susani, com. Traian Vuia, jud. Timiș. Punct. Grămurada de la Jupani. Patrimonium Banaticum 8, 2018, 25-35.

Dietrich 2015 - L. Dietrich: A new world order: the spread of channlled ware in Late Bronze Age and Early Iron Age Transylvania. In: P. Suchowska-Ducke/S. Scott Reiter/H. Vandkilde (eds.): Forging Identities. The Mobility of Culture in Bronze Age Europe. BAR International Series 2772. Oxford 2015, 165-173.

Dömötör 1897 - L. Dömötör: Ôskori Leletekről Arad- És Temes-Megyében. Archaeologiai Értesítő17, 1897, 261-264.

Dörner 1970 - E. Dörner: Cercetări şi săpături arheologice în județul Arad. Materiale și Cercetări Arheologice 9, 1970, 445-466.

Duffy et al. 2019 - P. R. Duffy/G. M. Parditka/J. I. Giblin/ L. Paja: The problem with tells. Lessons learned from absolute dating of Bronze Age mortuary ceramics in Hungary. Antiquity 93, 2019, 63-79.

Filipović et al. 2020 - D. Filipović/J. Meadows/M. Dal Corso/ W. Kirleis/A. Alsleben/Ö. Akeret/F. Bittmann/G. Bosi/ B. Ciută/D. Dreslerová/H. Effenberger/F. Gyulai/A. G. Heiss/M. Hellmund/S. Jahns/T. Jakobitsch/M. Kapcia/ S. Klooß/M. Kohler-Schneider/H. Kroll/P. Makarowicz/E. Marinova/T. Märkle/A. Medović/A. M. Mercuri/ A. Mueller-Bieniek/R. Nisbet/G. Pashkevich/R. Perego/ P. Pokorný/Ł. Pospieszny/M. Przybyła/K. Reed/J. Rennwanz/H.-P. Stika/A. Stobbe/T. Tolar/K. Wasylikowa/ J. Wiethold/T. Zerl: New AMS ${ }^{14} \mathrm{C}$ dates track the arrival and spread of broomcorn millet cultivation and agricultural change in prehistoric Europe. Scientific Reports 10: 13698, 2020.

DOI: https://doi.org/10.1038/s41598-020-70495-z

Fischl 2000-K. P. Fischl: Szőreg-C (Szőreg-Sziv utca) bronzkori temetője. A Móra Ferenc Múzeum Évkönyve. Studia Archaeologica 6, 2000, 77-138.

Foltiny 1957 - I. Foltiny: A Halomsíros és Lausitzi kultúra nyomai Szeged Környékén. Régészeti Füzetek 4. Budapest 1957.

Furmánek 1977 - V. Furmánek: Pilinyer Kultur. Slovenská archeológia 25, 1977, 251-369.

Furmánek/Veliačik/Vladár 1991 - V. Furmánek/L. Veliačik/ J. Vladár: Slovensko v dobe bronzovej. Bratislava 1991.

Gogâltan 1994 -F. Gogâltan: Giroc, jud. Timiş. Cronica cercetărilor arheologice. Campania 1993. In: A XXVIII-a sesiune națională de rapoarte arheologice. Satu Mare, 12.-15. mai 1994. București 1994, 28.

Gogâltan 1998 -F. Gogâltan: The Cruceni-Belegiš Cemetery of Livezile (Tovădia), Commune Banloc, District Timiș (Romania). In: P. Roman (ed.): The Thracian World at the Crossroads of Civilizations. Bucharest 1998, 181-205.

Gogâltan 1999 - F. Gogâltan: Bronzul timpuriu şi mijlociu în Banatul românesc şi pe cursul inferior al Mureşului I. Cronologia şi descoperirile de metal. Timişoara 1999.

Gogâltan 2001 - F. Gogâltan: The Settlement of Căşeiu and Some Problems Concerning the Late Bronze Age in the Center and Northern Transylvania. In: C. Kacsó (Hrsg.): Der nordkarpatischen Raum in der Bronzezeit. Symposium Baia Mare, 7.-10. Oktober 1998. Baia Mare 2001, 191-214.

Gogâltan 2004 - F. Gogâltan: Bronzul mijlociu în Banat. Opinii privind grupul Corneşti-Crvenka. In: P. Rogozea/ V. Cedică (Red.): Festschrift für Florin Medeleț. Zum 60. Geburtstag. Timişoara 2004, 79-153.

Gogâltan 2015 - F. Gogâltan: The Early and Middle Bronze Age Chronology on the Eastern Frontier of the Carpathian Basin: Revisited after 15 Years. In: R. E. Németh/B. Rezi (eds.): Bronze Age Chronology in the Carpathian Basin. Proceedings of the International Colloquium from Târgu Mureș. 2-4 October 2014. Cluj-Napoca 2015, 53-95.

Gogâltan 2017 - F. Gogâltan: The Bronze Age Multilayered Settlements in the Carpathian Basin (cca. 2500-1600/1500 BC). An old catalogue and some chronological problems. Journal of Ancient History and Archaeology 4, 2017, 28-63.

Gogâltan 2019 - F. Gogâltan: Despre cronologia absolută a bronzului târziu în estul Bazinului Carpatic. Tyragetia, s. n. 13 (28), 2019, 45-70.

Gogâltan/Popa 2016 - F. Gogâltan/C. I. Popa: Gligoreşti „Holoame" (Kreis Cluj) eine spätbronzezeitliche Siedlung aus Mittelsiebenbürgen. In: A. Zanoci/ 
E. Kaiser/M. Kashuba/E. Izbitser/M. Băț (eds.): Mensch, Kultur und Gesellschaft von der Kupferzeit bis zur frühen Eisezeit im Nördlichen Eurasien. Beiträge zu Ehren zum 60. Geburtstag von Eugen Sava. Man, culture, and society from the Copper Age until the Early Iron Age in Northern Eurasia. Contributions in honour of the $60^{\text {th }}$ anniversary of Eugen Sava. Chișinău 2016, 181-202.

Gogâltan/Sava 2010 -F. Gogâltan/V. Sava: Sântana Cetatea Veche. A Bronze Age earthwork on the lower Mureş. Arad 2010.

Gogâltan/Sava 2014 - F. Gogâltan/V. Sava: Depozitul de bronzuri de la Lipova, jud. Arad. Terra Sebus. Acta Musei Sabesiensis 6, 2014, 183-209.

Gogâltan/Sava 2018 - F. Gogâltan/V. Sava: A Violent End. An Attack with Clay Sling Projectiles against the Late Bronze Age Fortification in Sântana (South-Western Romania). In: Hansen/Krause 2018, 349-370.

Gogâltan/Sava 2019 - F. Gogâltan/V. Sava: Înainte de apariția mega-forturilor bronzului târziu de la Mureșul de jos (2000/1900-1600/1500 BC). Crisia 49, 2019, 67-91.

Gogâltan/Sava/Krause 2019 - F. Gogâltan/V. Sava/R. Krause: Sântana-Cetatea Veche. A Late Bronze Age Mega-fort in the Lower Mures Basin in Southwestern Romania. In: Hansen/Krause 2019a, 191-221.

Gogâltan/Stavilă 2020 - F. Gogâltan/A. Stavilă: The Late Bronze Age settlement from Giroc (Timiș County). Archaeological excavation from 1992-1993. Ziridava. Studia Archaeologica 34, 2020, 189-242.

Gumă 1993 - M. Gumă: Civilizația primei epoci a fierului în sud-vestul României. Bibliotheca Thracologica 4. Bucureşti 1993.

Gumă 1997 - M. Gumă: Epoca Bronzului în Banat. Orizonturi cronologice şi manifestări culturale. Bibliotheca Historica et Archaeologica Banatica 5. Timişoara 1997.

Hansen 2019a - S. Hansen: Die Burganlage von Teleac und das frühes Eisen in Südeuropa. In: Hansen/Krause 2019b, 201-225.

Hansen $2019 b$ - S. Hansen: Hillforts and Weaponry in the Early and Middle Bronze Age. In: Hansen/Krause 2019a, 93-132.

Hansen/Krause 2018 - S. Hansen/R. Krause (Hrsg.): Bronzezeitliche Burgen zwischen Taunus und Karpaten. Bronze Age Hillforts between Taunus and Carpathian Mountains. Beiträge der Ersten Internationalen LOEWE-Konferenz vom 7. bis 9. Dezember 2016 in Frankfurt/M. Proceedings of the First International LOEWE Conference, 7-9 december 2016 in Frankfurt/M. Universitätsforschungen zur prähistorischen Archäologie 319. Prähistorische Konfliktforschung 2. Bonn 2018.

Hansen/Krause 2019a - S. Hansen/R. Krause (eds.): Materialisierung von Konflikten. Materialisation of Conflicts. Beiträge der Dritten Internationalen LOEWE-Konferenz vom 24. bis 27. September 2018 in Fulda. Proceedings of the Third International LOEWE Conference, 24-27 September 2018 in Fulda. Universitätsforschungen zur prähistorischen Archäologie 346. Prähistorische Konfliktforschung 4. Bonn 2019.

Hansen/Krause 2019b-S. Hansen/R. Krause (eds.): Bronze Age Fortresses in Europe. Proceedings of the Second International LOEWE Conference, 9-13 October 2017 in Alba Iulia. Universitätsforschungen zur prähistorischen Archäologie 335. Prähistorische Konfliktforschung 3. Bonn 2019.

Harding 2007 - A. Harding: Warriors and Weapons in Bronze Age Europe. Budapest 2007.

Harding/Kavruk 2013 - A. Harding/V. Kavruk: Chapter 4. Transylvania. In: A. Harding/V. Kavruk (eds.): Explora- tions in Salt Archaeology in the Carpathian Zone. Budapest 2013, 41-153.

Ignat/Sava 2019 - A. Ignat/V. Sava: Late Bronze Age funerary practices in the Lower Mureș Basin. Revista Arheologică 15, 2019, 5-20.

Jung 2016 - R. Jung: „,Friede den Hütten, Krieg den Palästen!“ In the Bronze Age Aegean. In: H. Meller/H.-P. Hahn/ R. Jung/R. Risch (Hrsg.): Arm und Reich - Zur Ressourcenverteilung in prähistorische Gesellschaften. Rich and Poor - Competing for resources in prehistoric societies. 8. Mitteldeutscher Archäologentag vom 22. Bis 24. Oktober 2015 in Halle (Saale). $8^{\text {th }}$ Archaeological Conference of Central Germany October 22-24, 2015 in Halle (Saale). Halle (Saale) 2016, 553-575.

Jung/Mehofer 2013 - R. Jung/M. Mehofer: Mycenaean Greece and Bronze Age Italy. Cooperation, Trade or War? Archäologisches Korrespondenzblatt 43, 2013, 175-193.

Kacsó 1990 - C. Kacsó: Bronzul târziu în nord-vestul României. Symposia Thracologica 8, 1990, 41-50.

Kacsó 1993 - C. Kacsó: Depozitul de bronzuri de la Vânători. Analele Banatului 2, 1993, 171-178.

Kacsó 2001 - C. Kacsó: Zur chronologischen und kulturellen Stellung des Hügelgräberfeldes von Lăpuș. In: C. Kacsó (Hrsg.): Der Nordkarpatische Raum in der Bronzezeit. Symposium Baia Mare. 7.-10. Oktober 1998. Bibliotheca Marmatia I. Baia Mare 2001, 231-278.

Kacsó 2011 - C. Kacsó: Die Hügelnekropole von Lăpuș. Eine zusammenfassende Einleitung. In: S. Berecki/ R. E. Németh/B. Rezi (eds.): Bronze Age Rites and Rituals in the Carpathian Basin. Proceedings of the International Colloquium from Târgu Mureș. 8-10 October 2010. Târgu Mureș 2011, 213-243.

Kacsó 2015 - C. Kacsó: Descoperiri din epoca bronzului de la Felnac (jud. Arad). Revista Bistriţei 29, 2015, 23-41.

Kapuran 2019 - A. Kapuran: Velebit, a Tumulus Culture Necropolis in the Southern Carpathian Basin (Vojvodina, Serbia). BAR international Series 2942. Oxford 2019.

Kemenczei 1984 - T. Kemenczei: Die Spätbronzezeit in Nordostungarn. Budapest 1984.

Kemenczei 1991 - T. Kemenczei: A pécskai/Pecica második bronzlelet. Folia Archaeologica 42, 1991, 28-48.

Kósa 2018- P. Kósa: Baks-Temetőpart. Analysis of a Gáva-ceramic style mega-settlement. Communicationes Archaeologicae Hungariae 2018, 5-87.

Krause 2019a-R. Krause: Zur Professionalisierung des Krieges in der Bronzezeit. In: Hansen/Krause 2019a, 13-43.

Krause $2019 b$ - R. Krause: Fortresses and Fortifications. On Fortified Hilltop Settlements of the Bronze Age. In: Hansen/Krause 2019b, 1-16.

Krause et al. 2019 - R. Krause/A. Szentmiklosi/B. Heeb/ R. Lehmphul/K. Teinz/A. Bălărie/C. Herbig/A. Stobbe/ J. Schmid/D. Schäffler/M. Wemhoff: Cornești-Iarcuri. Die Ausgrabungen 2013 und 2014 in der befestigten Großsiedlung der späten Bronzezeit im rumänischen Banat. Eurasia Antiqua 22, 2019, 133-184.

Krause et al., in press - R. Krause/V. Sava/A. Stobbe/M. Gumnior/F. Gogâltan: Die bronzezeitliche Befestigung von Sântana - Cetatea Veche am Unterlauf des Mureş in Rumänien. Zur Topographie, Umwelt und Geschichte der Befestigungen und ihres zentralen Großkomplexe. Eurasia Antiqua 24, in press.

Kristiansen/Larsson 2005 - K. Kristiansen/T. B. Larsson: The Rise of Bronze Age Society. Travels, Transmissions and Transformations. Cambridge 2005. 
Kristiansen/Suchowska-Ducke 2015 - K. Kristiansen/P. Suchowska-Ducke: Connected Histories: the Dynamics of Bronze Age Interaction and Trade 1500-1100 BC. Proceedings of the Prehistoric Society 81, 2015, 361-392. DOI: https://doi.org/10.1017/ppr.2015.17

László 1994 - A. László: Începuturile epocii fierului la est de Carpați. Culturile Gáva-Holohrady și CorlăteniChișinău pe teritoriul Moldovei. Bibliotheca Thracologica 6. București 1994.

László 2019 - A. László: Archaeological-Historical Information and Radiocarbon Dating: Problems of the Late Bronze-Early Iron Age Chronology of the Carpathian-Danubian-Balkan Region. In: N. Plincaș/C. C. Ponta (eds.): Bridging Science and Heritage in the Balkans. Studies in archaeometry, cultural heritage restoration and conservation. Oxford 2019, 52-63.

Lehmphul et al. 2019 - R. Lehmphul/B. Heeb/A. Szentmiklosi/ A. Stobbe/R. Krause: The genesis of the fortification of Cornești-larcuri near the Mureș lower course (Romanian Banat). A phase model on the chronology of the settlement and fortification structures. In: Hansen/ Krause 2019b, 253-278.

Levițki 1994 - O. Levițki: Cultura Hallstattului canelat la răsărit de Carpați. Bibliotheca Thracologica 7. București 1994.

Marta 2009 - L. Marta: The Late Bronze Age Settlements of Petea-Csengersima. Satu Mare 2009.

Marta et al. 2010 - L. Marta/D. V. Sana/I. Bejinariu/L. N. Márta/E. Berendi: The Late Bronze Age Settlement of Nyíregyháza-Oros "Úr Csere". Satu Mare 2010.

Marta et al. 2012 - L. Marta/C. Astaloş/C. Virag/A. N. Hágó/ Z. Kádas/D. Iegar: Pecica, jud. Arad. Punct. Sit 15, km $28+600-29+100$. In: Cronica cercetărilor arheologice. Campania 2011. XLVI-a Sesiune Națională de rapoarte arheologice. Târgu Mureș, 23.-26. mai 2012. Bucureşti 2012, 288-290.

Metzner-Nebelsick 2012 -C. Metzner-Nebelsick: Channelled pottery in Transylvania and beyond - ritual and chronological aspects. Satu Mare - Studii și Comunicări 28/1, 2012, 65-82.

Metzner-Nebelsick/Kacsó/Nebelsick 2010 - C. Metzner-Nebelsick/C. Kacsó/L. D. Nebelsick: A Bronze Age ritual structure on the edge of the Carpathian Basin. Satu Mare - Studii și Comunicări 26/1, 2010, 219-228.

Molloy/Horn 2020 - B. Molloy/C. Horn: Weapons: Warriors and Warfare in Bronze Age Europe. In: G. G. Fagan/ L. Fibiger/M. Hudson/M. Trundle (eds.): The Cambridge World History of Violence. The Cambridge World History of Violence. Cambridge 2020, 117-141.

DOI: https://doi.org/10.1017/9781316341247.007

Molloy et al. 2017 - B. Molloy/D. Jovanović/N. Mirković-Marić/M. Marić/P. Mertl/L. Milašinović: The Late Bronze Age fortification of Gradište Idjoš in its regional context. In: B. S. Heeb/A. Szentmiklosi/R. Krause/ M. Wemhoff (eds.): Fortifications: The Rise and Fall of Defended Sites in the Late Bronze Age and Early Iron Age of South-East Europe. International Conference in Timişoara, Romania from November $11^{\text {th }}-13^{\text {th }}, 2015$. Berlin 2017, 161-172.

Molloy et al. 2020 - B. Molloy/D. Jovanović/C. Bruyère/ M. Marić/J. Bulatović/P. Mertl/C. Horn/L. Milašinović/ N. Mirković-Marić: A New Bronze Age Mega-fort in Southeastern Europe: Recent Archaeological Investigations at Gradište Iđoš and their Regional Significance. Journal of Field Archaeology, 2020.

DOI: https://doi.org/10.1080/00934690.2020.1734899
Molnár 2014 - Z. Molnár: Contribuții la cunoașterea culturii Otomani din nord-vestul Transilvaniei. Ceramică și metal. Patrimonium Archaeologicum Transylvanicum 10. Cluj-Napoca 2014.

Motzoi-Chicideanu 2011 - I. Motzoi-Chicideanu: Obiceiuri funerare în Epoca Bronzului la Dunărea Mijlocie și Inferioară. București 2011.

Mozsolics 1985 - A. Mozsolics: Bronzefunde aus Ungarn. Budapest 1985.

Mureşan/Caba 2007 - A. Mureşan/I. Caba: Depozitul hallstattian de bronzuri de la Apateu, județul Arad. In: P. Hügel/A. Mureşan (ed.): Istoricul Liviu Mărghitan la a 70-a aniersare. Arad 2007, 112-118.

Nagy 2005 - M. Nagy: A halomsíros kultúra leletei Szentes környékén. A Móra Ferenc Múzeum Évkönyve. Studia Archaeologica 11, 2005, 7-36.

Németi 2009 - J. Németi: The Hajdúbagos. Pișcolt-Cehăluț Group. In: S. Berecki/R. E. Németh/B. Rezi (eds.): Bronze Age Communities in the Carpathian Basin. Proceedings of the International Colloquium from Târgu Mureș, 24-26 October 2008. Cluj-Napoca 2009, 203-221.

Nicodemus/Motta/O'Shea 2015 - A. Nicodemus/L. Motta/ J. M. O'Shea: Archaeological Investigations at Pecica "Şanțul Mare" 2013-2014. Ziridava. Studia Archaeologica 29, 2015, 105-118.

O'Brien 2018 - W. O'Brien: Hillforts and Warfare in Bronze Age Ireland. In: Hansen/Krause 2018, 241-264.

O'Shea et al. 2019 - J. M. O'Shea/G. Parditka/A. Nicodemus/ K. Kristiansen/K.-G. Sjögren/L. Paja/G. Pálfi/L. Milašinović: Social formation and collapse in the Tisza-Maros region: dating the Maros Group and its Late Bronze Age successors. Antiquity 93, 2019, 604-623. DOI: http://dx.doi.org/10.15184/aqy.2019.40

Pankau 2004 - C. Pankau: Die älterhallstattzeitliche Keramik aus Mediaş/Siebenbürgen. Universitätsforschungen zur prähistorischen Archäologie 109. Bonn 2004.

Petrescu-Dîmboviţa 1977 - M. Petrescu-Dîmbovița: Depozitele de bronzuri din România. Bucureşti 1977.

Pop 2009 - D. Pop: The Middle Bronze Age Settlement of Petea-Csengersima. Satu Mare 2009.

Popa/Totoianu 2010 - C. I. Popa/R. Totoianu: Noi opinii privitoare la evoluția culturală a bronzului târziu în zona central și sud-vest transilvăneană. In: C. I. Popa/ R. Totoianu (eds.): Aspecte ale epocii bronzului în Transilvania (între vechile şi noile cercetări). Sebeș 2010, 171-291.

Przybyła 2009 - M. S. Przybyła: Intercultural Contacts in the Western Carpatian Area at the Turn of the $2^{\text {nd }}$ and $1^{\text {st }}$ Millennia BC. Warszawa 2009.

Quinn et al. 2020 - C. P. Quinn/H. Ciugudean/G. Bălan/ G. Hodgins: Rethinking time, culture and socioeconomic organization in Bronze Age Transylvania. Antiquity 94, 2020, 44-61. DOI: https://doi.org/10.15184/aqy.2019.231

Radu 1971 - O. Radu: Asupra unui mormânt de incinerare de la Cruceni. Tibiscus 1, 1971, 19-23.

Radu 1973 - O. Radu: Cu privire la necropola de la Crucen (jud. Timiş). Studii și Cercetări de Istorie Veche și Arheologie 24, 1973, 503-520.

Sava E. 2002 - E. Sava:Die Bestattungen der Noua-Kultur. Ein Beitrag zur Erforschung spätbronzezeitlicher Bestattungsriten zwischen Dnestr und Westkarpaten. Prähistorische Archäologie in Südosteuropa 19. Kiel 2002.

Sava V. 2014 - V. Sava: Un vas de tip butoi descoperit în aşezarea aparţinând epocii bronzului de la Şagu "Sit A1_1”. Terra Sebus. Acta Musei Sabesiensis 6, 2014, 127-146. 
Sava V., in press - V. Sava: The Late Bronze Age settlement at Șagu and the early use of the channeled pottery. Analele Banatului 27, in press.

Sava/Andreica 2013 - V. Sava/L. Andreica: Social Identity in the Lower Mureş Basin During the Late Bronze Age. Two Seal-Headed Pins from Pecica "Site 14" Cemetery. In: I. V. Ferencz/N. C. Rişcuța/O. T. Bărbat (eds.): Archaeological Small Finds and Their Significance. Proceedings of the Symposion: Costume as an Identity Expression. Cluj-Napoca 2013, 49-76.

Sava/Ignat 2014 - V. Sava/A. Ignat: Acquiring significance. Constructing warrior's identity at the Lower Mureş Basin. Annales d'Universite "Valahia" Targoviste. Section d'Archeologie et d'Histoire 16, 2014, 7-35.

Sava/Ignat 2016 - V. Sava/A. Ignat: The Beginning of the Late Bronze Age in the Lower Mureş Basin. An Overview. In: F. Gogâltan/C. Cordoş (eds.): Prehistoric settlements. Social, economic and cultural aspects. Seven studies in the Carpathian area. Cluj-Napoca 2016, 181-199.

Sava/Gogâltan 2019 - V. Sava/F. Gogâltan: Bazinul Mureșului de Jos la începutul bronzului târziu (1600/1500-1400 BC). In: D. R. Hrib (ed.): In honorem Prof. univ. dr. Sabin Adrian Luca Istorie şi destin. Sibiu 2019, 223-234.

Sava/Gogâltan/Krause 2019 - V. Sava/F. Gogâltan/R. Krause: First Steps in the Dating of the Bronze Age Mega-Fort in Sântana-Cetatea Veche (Southwestern Romania). In: Hansen/Krause 2019b, 161-176.

Sava/Hurezan/Mărginean 2011 - V. Sava/G. P. Hurezan/F. Mărginean: Şagu "Sit A1_1" a Late Bronzea Age Settlement on the Lower Mureş. Cluj-Napoca 2011.

Sava/Hurezan/Mărginean 2012 - V. Sava/G. P. Hurezan/F. Mărginean: Late Bronze Age Metal Artefacts Discovered in Şagu, Site "A1_1", Arad - Timişoara Highway (km 0 + 19.900-0 + 20.620). Studia Arheologica 26, 2012, 83-107.

Sava/Mărginean/Ursuțiu 2017 - V. Sava/F. Mărginean/ A. Ursutiu: The Eneolithic Cemetery in Pecica "Est", Arad County. Ziridava. Studia Archaeologica 31, 2017, 55-68.

Sánta 2011 - G. Sánta: Settlements of the Tumulus Culture in Hungary. Antaeus 31, 2010, 2011, 513-528.

Sánta 2017 - G. Sánta: New Results in the Study of Settlement Patterns of the Bronze Age Tumulus Culture. In: G. Kulcsár/G. V. Szabó with V. Kiss/G. Váczi (eds.): State of the Hungarian Bronze Age Research. Proceedings of the conference held between $17^{\text {th }}$ and $18^{\text {th }}$ of December 2014. Ösrégészeti Tanulmányok/Prehistoric Studies 2. Budapest 2017, 95-106.

Soroceanu 1991 - T. Soroceanu: Studien zur Mureş-Kultur. Buch am Erlbach 1991.

Soroceanu 2012 - T. Soroceanu: Die Kupfer- und Bronzedepots der frühen und mittleren Bronzezeit in Rumänien. Depozitele de obiecte din cupru şi bronz din România. Epoca timpurie şi mijlocie a bronzului. Archaeologia Romanica V. Cluj-Napoca - Bistrița 2012.

Stavilă 2012 - A. Stavilă: The pottery from the Bronze Age settlement of Timisoara - "Fratelia". A general statistical approach. Annales d'Université Valahia Targoviste. Section d'Archeologie et d'Histoire 14, 2012, 29-45.
Stika/Heiss 2013 - H.-P. Stika/A. G. Heiss: Plant cultivation in the Bronze Age. In: H. Fokkens/A. Harding (eds.): The Oxford Handbook of the European Bronze Age. Oxford 2013, 348-369.

Stratan/Vulpe 1977 - I. Stratan/A. Vulpe: Der Hügel von Susani. Praehistorische Zeitschrift 52, 1977, 28-60.

Szabó 2017 - G. V. Szabó: A Gáva-kerámiastílus kora. Az Alföld a hajdúböszörményi szitulák földbekerülésének időszakában. In: G. V. Szabó/M. Bálint/G. Váczi (szerk.): A második hajdúböszörményi szitula és kapcsolatrendszere. The second situla of Hajdúböszörmény and its relations. Budapest - Hajdúböszörmény 2017, 231-278.

Szentmiklosi 2009 - A. Szentmiklosi: Aşezările culturii Cruceni-Belegiš în Banat. Unpublished diploma thesis. University of Alba Iulia. Alba Iulia 2009.

Szeverényi et al. 2017 - V. Szeverenyi/P. Czukor/A. Priskin/ C. Szalontai: Recent work on Late Bronze Age fortified settlements in south-east Hungary. In: B. S. Heeb/ A. Szentmiklosi/R. Krause/M. Wemhoff (eds.): Fortifications: The Rise and Fall of Defended Sites in the Late Bronze Age and Early Iron Age of South-East Europe. International Conference in Timişoara, Romania from November $11^{\text {th }}-13^{\text {th }}, 2015$. Berlin $2017,135-148$.

Tasić 1984 - N. Tasić: Mlađa faza Belegiš kulture i njen položaj u raznogu kultura poznog bronzanog doba u yugoslovenskom podunavlju. Balkanika 15, 1984, 33-44.

Tasić 2001 - N. Tasić: The problem of the Belegiš (Belegiš-Cruceni, Belegiš-Bobda) Culture. Genesis, Duration and Periodization. In: F. Drașovean (red.): Festschrift für Gheorghe Lazarovici zum 60. Geburtstag. Bibliotheca Historica et Archaeologica Banatica 30. Timişoara 2001, 311-321.

Terberger et al. 2018 - T. Terberger/D. Jantzen/J. Krüger/ G. Lidke: Das bronzezeitliche Kampfgeschehen im Tollensetal - ein Großereignis oder wiederholte Konflikte? In: Hansen/Krause 2018, 103-123.

Trogmayer 1975 - O. Trogmayer: Das Bronzezeitliche Gräberfeld bei Tápé. Budapest 1975.

Uhnér et al. 2019 - C. Uhnér/H. Ciugudean/S. Hansen/F. Becker/G. Bălan/R. Burlacu-Timofte: The Teleac Hillfort in Southwestern Transylvania: the Role of the Settlement, War and the Destruction of the Fortification System. In: Hansen/Krause 2019b, 177-200.

Ursuțiu 2002 - A. Ursuțiu: Etapa mijlocie a primei vârste a fierului în Transilvania (Cercetările de la Bernadea, com. Bahnea, jud. Mureş). Cluj-Napoca 2002.

Vanzetti 2013 - A. Vanzetti: 1600? The rise of the Terramara system (Northern Italy). In: H. Meller/F. Bertemes/ H.-R. Bork/R. Risch (Hrsg.): 1600 - Kultureller Umbruch im Schatten des Thera-Ausbruchs? 4. Mitteldeutscher Archäologentag vom 14. bis 16. Oktober 2011 in Halle (Saale). Tagungen des Landesmuseums fur Vorgeschichte Halle 9. Halle (Saale) 2013, 267-282.

Vasiliev/Aldea/Ciugudean 1991 - V. Vasiliev/I. A. Aldea/H. Ciugudean: Civilizația dacică timpurie în aria intracarpatică a României. Contribuții arheologice. Aşezarea fortificată de la Teleac. Cluj-Napoca 1991.

Victor Sava, Dr.

Museum of Arad

Piața George Enescu

RO - 310131 Arad

sava_vic@yahoo.com 


\title{
Mladšia doba bronzová v juhovýchodnej časti Karpatskej kotliny
}

\author{
Victor Sava
}

\author{
SÚHRN
}

Opustenie niektorých tellových sídlisk zo strednej doby bronzovej v oblasti dolného Mureša na juhovýchode Karpatskej kotliny viedlo v priebehu 15. stor. pred n. 1. k výstavbe rozsiahlych hradísk, ktoré zanikli v 13. stor. pred n. 1. Reprezentatívne lokality boli síce archeologicky skúmané, ale vel'ké množstvo získaných artefaktov, vrátane keramiky zatial' nebolo podrobne analyzované. Cielom práce je vyplnit túto medzeru a predstavit podrobnú analýzu spájajúcu dostupné rádiouhlíkové dáta, polohy, $\mathrm{z}$ ktorých boli tieto vzorky odobraté a súvisiace nálezy keramiky. Do databázy je zahrnutých 34 rádiouhlíkových dát z 33 sídliskových objektov zo siedmich lokalít (Foeni-Gomila Lupului; Miroc-Mescal, Pecica-východ, Pecica-lokalita 14, Sântana-Cetatea Veche, Șagu-lokalita A1_1, Tápé-Széntéglaégető), ktoré stanovili absolútnu chronológiu keramiky z oblasti dolného Mureša. Z uvedeného počtu objektov pochádza 552 úplných nádob a črepov. Databáza obsahuje aj informácie o všetkých hlavných morfologických znakoch keramiky (tvar a výzdoba), spolu s technologickými vlastnostami (techniky zdobenia).

Podla tradičnej relatívnej chronológie bol vo Vnútorných Východných Karpatoch počiatok staršej doby bronzovej alebo vznik keramiky štýlu Cruceni-Belegiš I, Noua, Lăpuş datovaný do doby okolo roku 1300 pred n. 1. (Ciugudean 2010, obr. 4). Po desatročiach výskumov na významných náleziskách a po zozbieraní a publikovaní značného množstva rádiouhlíkových dát bol začiatok staršej doby bronzovej posunutý hlbšie do minulosti (Gogâltan 2019, 48-51; Sava/Gogâltan 2019; Sava/Ignat 2016, 192-195). To sa potvrdilo novými rádiouhlíkovými dátami z dolného Mureša, ktoré zatial' naznačujú, že staršia doba bronzová sa $\mathrm{v}$ tomto regióne začala $\mathrm{v} 16$. stor. pred $\mathrm{n}$. 1 .

Typologická analýza skúmaného súboru keramiky ukázala, že pôvodný tvar bolo možné rekonštruovat len u 25,36 \% črepov (140 kusov). Spolu sa rozpoznalo devät hlavných tvarov, ktoré boli d’alej rozdelené na 23 podtypov (obr. 16; tabela 2). Podarilo sa určit spolu 59 výzdobných motívov, z ktorých väčšina bola rytá. Nasledovalo kanelovanie, reliéfna výzdoba, vtlačovanie a pseudošnúrová výzdoba (obr. 26; tabela 3). Na analyzovanej keramike bolo teda identifikovaných pät základných výzdobných techník: rytie (1), kanelovanie (2), pseudošnúrová výzdoba (3), reliéfna výzdoba (4) a vtláčaná výzdoba (5). So pseudošnúrovaním sa stretávame len na keramike z Giroc-Mescal a Foeni-Gomila Lupului. Identifikovali sa dva hlavné vzory vo vývoji výzdobných techník a špecifické aspekty istej obmedzenej chronologickej postupnosti. Po zohladnení týchto zistení v širšom kontexte hlavných udalostí v regióne možno konštatovat', že po roku 1400 pred n. 1. (časový úsek, ktorý korešponduje so vznikom a vývojom rozsiahlych hradísk) sa kanelovaná výzdoba stala dominantnou výzdobnou technikou na úkor rytej výzdoby. Navyše fakt, že nádob s kanelovanou výzdobou je v najstarších kontextoch (približne 1600-1400 pred n. 1.) viac než nádob s rytou výzdobou, otvára otázky týkajúce sa systémov tradičnej relatívnej chronológie. Tá pripisuje rytej výzdobe starší pôvod a kanelovanej výzdobe mladší. Pri rozdelení výzdobných techník podla archeologických lokalít a troch hlavných časových období zastúpených v tejto štúdii si možno všimnút, že lokality sa zhlukujú do dvoch skupín (obr. 21). Prvá skupina obsahuje lokality z Foeni-Gomila Lupului, Giroc-Mescal a Tápé. Medzi analyzovanými kontextmi z týchto troch lokalít jasne prevláda rytá výzdoba, kým pseudošnúrová výzdoba sa nachádza len na lokalitách Foeni a Giroc. Navyše kanelovaná výzdoba je na keramike z tejto skupiny vel'mi zriedkavá. $V$ druhej skupine (pozostávajúcej z lokalít Pecica-poloha 14, Sântana-Cetatea Veche a Sagu-poloha A1_1) prevláda kanelovaná výzdoba už od obdobia 1600-1500 pred n. 1., zatial čo medzi rokmi 1400 a 1300 pred n. 1. má kanelovanú výzdobu viac ako $60 \%$ analyzovanej keramiky. Výsledky analýzy odhalili dva hlavné prúdy vo výzdobných technikách v oblasti dolného Mureša. Zdá sa, že na niektorých lokalitách, napríklad Foeni, Giroc a Tápé, pokračovala výzdobná tradícia staršej doby bronzovej, kým na iných lokalitách, ako Pecica, Sântana a Sagu, sa používala kanelovaná výzdoba už v strednej dobe bronzovej I. V tejto súvislosti by sme mali spochybnit’ alebo aspoň upresnit’ doterajšie názory na rozšírenie kanelovanej keramiky zo severného regiónu Tisy, severozápadného Rumunska a severovýchodného Mad’arska (pozri napr. Dietrich 2015, 166; Metzner-Nebelsick 2012, 65, 66, 72). Na viac ako 52 \% keramických črepoch zaregistrovaných $\mathrm{v}$ databáze sa výzdobné motívy dali zrekonštruovat'.

Ďalším dôležitým aspektom v diskusii o vzniku a vývoji keramiky strednej doby bronzovej je viditelné pokračovanie tradície staršej doby bronzovej v keramických tvaroch, výzdobných technikách a motívoch (Duffy et al. 2019, obr. 6; Sava/Gogâltan 2019, 227; Sava/Ignat 2016, 195). Analýza ukázala, že niektoré vlastnosti keramiky zo strednej doby bronzovej pretrvávali aj v mladšej dobe bronzovej. Zároveň môžeme pozorovat’ pokračovanie niektorých tvarov, výzdobných techník a motívov, ktoré sa vyvinuli v stupňoch I, II a III mladšej doby bronzovej (časové obdobie zodpovedajúce používaniu gávskej keramiky).

Vykonaná analýza ukázala, že vytýčenie úsekov relatívnej chronológie na základe typologického vývoja keramiky nemôže nahradit rádiouhlíkové dáta. S pribúdajúcimi dostupnými absolútnymi dátami je čoraz jasnejšie, že typologickú chronológiu je potrebné podstatne zrevidovat'. Cielom tejto práce je, okrem iného, stanovit’ 
absolútnu chronológiu keramiky, ktorá pochádza z vyššie spomenutých lokalít a vytvorit systém relatívnej chronológie, ktorý by sa dal lahko aplikovat na oblast' dolného Mureša. Kombinácia kontextovej analýzy s absolútnou chronológiou a typológiou tvarov a keramickej výzdoby ukázala, že stanovit' markery relatívnej chronológie na základe vývoja špecifických artefaktov je takmer nemožné. Namiesto toho sa zdá, že zdôraznenie historických udalostí všeobecného charakteru je lepším kritériom pre vytvorenie systému relatívnej chronológie, ktorý by malo doplnit’ a potvrdit použitie rádiouhlíkových dát. Hlavné udalosti, ktoré sa odohrali v údolí dolného Mureša počas mladšej doby bronzovej už boli pertraktované v predchádzajúcich publikáciách (Gogâltan/Sava 2019; Sava/Gogâltan 2019; Sava/Ignat 2016).

Predmetná štúdia ponúka ponúka nový pohlad na chronologický vývoj dolného Mureša a okolitých regiónov v strednej dobe bronzovej. V prvom rade rádiouhlíkové dáta z lokalít Giroc-Mescal, Foeni-Gomila Lupului, Sagu-poloha A1_1 a Pecica-poloha 14 potvrdzujú predchádzajúce predpoklady (Sava/Gogâltan 2019, 223; Sava/Ignat 2016,
191, 192), že posledná vrstva staršej doby bronzovej z lokality Pecica-Santul Mare je súčasná s niekol'kými sídliskami a pohrebiskami, ktoré je možné priradit k I. stupňu strednej doby bronzovej na základe v nich nájdených súborov. $S$ počiatkom stavania rozsiahlych hradísk (napr. Sântana-Cetatea Veche) je v materiáli čoraz viac viditelnejšia štandardizácia keramických tvarov, výzdoby a rozšírené preberanie kanelovanej výzdoby. Tieto vlastnosti sú ešte výraznejšie po zničení rozsiahlych hradísk a rozšírení keramiky gávskeho typu.

Výsledky analýzy, ktorá kombinovala keramiku s rádiouhlíkovými dátami a nálezovými kontextmi ukázali, že keramika sa nedá použit’ ako stabilný chronologický ukazovatel' pre vytvorenie systémov relatívnej chronológie. Zároveň je potrebné zdôraznit', aké dôležité je zahrnút rádiouhlíkové dáta do typologickej a štylistickej analýzy keramiky. Analýza tiež odhalila, že vývoj istého tvaru výzdobnej techniky alebo vzoru môže sledovat' rôzne trajektórie, dokonca aj v rámci toho istého mikroregaiónu. To spochybňuje paradigmu archeologických kultúr/štýlov rovnomerne rozšírených v rozlahlých oblastiach. 